Supporting information

Stereoselective Furan-Iminium Cation Cyclization in the Construction of the Core Structure of Manzamine A

Kazuyuki Tokumaru, Shigeru Arai and Atsushi Nishida Graduate School of Pharmaceutical Sciences, Chiba University, Yayoi-cho 1-33,

Inage-ku, Chiba 263-8522, Japan
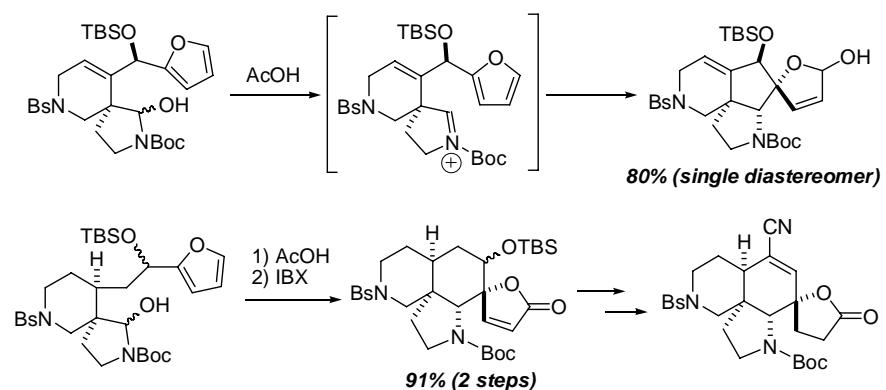

A new type of furan-iminium cation cyclization was developed and used to construct the $A B C$ ring of manzamine A. The cyclization proceeded at the 2-position with complete regio- and stereoselectivity to give a spiro-center. The product was efficiently converted to the highly substituted core structure of manzamine A 
General: All reactions were performed under Argon atmosphere. Solvents and reagents were purified prior to use following the guidelines of Perrin and Armarego. ${ }^{1}$ Purification of reaction products was carried out by flash chromatography using Fuji Silysia Chemical Ltd silica gel PSQ 60B. Analytical thin layer chromatography was performed on E. Merck $0.25 \mathrm{~mm}$ silica gel $60 \mathrm{GF}_{254}$ plates. Melting points were determined on a Yanagimoto micro melting point apparatus and were uncorrected. Infrared (IR) spectra were recorded on a JASCO FT/IR-230 spectrometer. NMR spectra were recorded on a JEOL JNM-ECP 400 spectrometer (400 MHz for ${ }^{1} \mathrm{H}$ NMR and $100 \mathrm{MHz}$ for ${ }^{13} \mathrm{C} \mathrm{NMR}$ ) and are reported in ppm using solvent as an internal standard ( $\mathrm{CDCl}_{3}$ at $\left.7.26 \mathrm{ppm}\right)$. Data reported as ( $\mathrm{s}$ = singlet, $\mathrm{d}$ = doublet, $\mathrm{t}$ = triplet, $\mathrm{q}$ = quartet, $\mathrm{m}$ = multiplet, $\mathrm{br}$ = broad; coupling constant(s) in Hz; integration). Elemental analyses and mass spectrometry were carried out at the Chemical Analysis Center of Chiba University.

\section{Synthesis of compound 6}

A $1.0 \mathrm{M}$ solution of LiHMDS in THF (14 mL, $14 \mathrm{mmol}$ ) was added dropwisely to a solution of 5 (5.5 g, 13 mmol) in THF (150 mL) at $-78{ }^{\circ} \mathrm{C}$. After $1 \mathrm{~h}, \operatorname{PhNTf}_{2}(5.0 \mathrm{~g}, 14 \mathrm{mmol})$ in THF $(15 \mathrm{~mL})$ was added via a cannula at the same temperature. Stirring was continued for additional $13 \mathrm{~h}$ at ambient temperature. The mixture was diluted with $\mathrm{CH}_{2} \mathrm{Cl}_{2}$ and filtered through a pad of alumina and eluted with $\mathrm{CH}_{2} \mathrm{Cl}_{2}$. The combined filtrates were concentrated in vacuo to give a residue which was purified by flash column chromatography on silica gel (hexane:AcOEt $=1: 1$ ) to afford the triflate 6 as a colorless solid $(5.1 \mathrm{~g}, 70 \%)$ : mp $130{ }^{\circ} \mathrm{C}$ (hexane-AcOEt); ${ }^{1} \mathrm{H}$<smiles>CCCC12CCN(S(=O)(=O)c3ccccc3)CC1CCN2C</smiles>

6 NMR (400 MHz, $\left.\mathrm{CDCl}_{3}\right) \delta$ 2.27-2.45 (m, 2H), 2.91 (dd, J = 0.9, $\left.11.7 \mathrm{~Hz}, 1 \mathrm{H}\right), 3.28-3.36(\mathrm{~m}$, 3H), 3.36 (dd, J = 1.3, 11.7 Hz, 1H), 3.81 (s, 3H), 4.10-4.26 (m, 2H), 4.60 (d, J = $14.5 \mathrm{~Hz}$, 1H), 5.93 (dd, $\mathrm{J}=$ 2.2, $5.1 \mathrm{~Hz}, 1 \mathrm{H}$ ), 6.87 (d like, $\mathrm{J}=8.7 \mathrm{~Hz}, 2 \mathrm{H}$ ), 7.15 (d like, $\mathrm{J}=8.7 \mathrm{~Hz}$, 2H), 7.55-7.81 (m, 5H); ${ }^{13} \mathrm{C}$ NMR (100 MHz, $\left.\mathrm{CDCl}_{3}\right) \delta 27.7,42.9,43.9,46.6,50.7,50.9$, 55.3, 114.2, 114.5, 118.1 (q, J = 320 Hz), 127.3, 127.4, 129.4, 129.5, 133.5, 135.5, 147.0, 159.3, 169.2; IR (thin film) v 1681, 1417, 1257, 1210, 1164, $968 \mathrm{~cm}^{-1}$; LRMS (FAB) m/z 561 (M+H), 419, 121; HRMS (FAB) m/z Calcd for $\mathrm{C}_{23} \mathrm{H}_{24} \mathrm{~F}_{3} \mathrm{~N}_{2} \mathrm{O}_{7} \mathrm{~S}_{2}(\mathrm{M}+\mathrm{H})$ 561.0977, Found 561.0950; Anal. Calcd for $\mathrm{C}_{23} \mathrm{H}_{23} \mathrm{~F}_{3} \mathrm{~N}_{2} \mathrm{O}_{7} \mathrm{~S}_{2} \mathrm{C}$ : 49.28, H: 4.14, N: 5.00, Found C: 49.67, H: 4.34, N: 4.93.

\section{Synthesis of compound 7}

To a solution of 6 ( $8.4 \mathrm{~g}, 15 \mathrm{mmol})$ and (2-furyl)tributyltin $(5.7 \mathrm{~mL}, 18 \mathrm{mmol})$ in THF (150 mL) were added $\mathrm{Pd}\left(\mathrm{PPh}_{3}\right)_{4}(1.2 \mathrm{~g}, 1.5 \mathrm{mmol})$ and $\mathrm{LiCl}(1.5 \mathrm{~g}, 36 \mathrm{mmol})$ successively and the mixture was stirred vigorously under CO atmosphere for $24 \mathrm{~h}$ at room temperature. The mixture was filtered through a pad of Celite ${ }^{\circledR}$ and eluted with

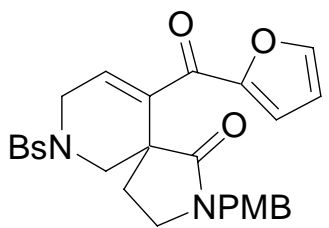

7 AcOEt. The combined filtrates were concentrated in vacuo to give a residue which was purified by flash column chromatography on silica gel (hexane:AcOEt $=1: 2$ ) to afford the 2-furylketone 7 as a colorless foam (6.6 g, 87\%): mp $168{ }^{\circ} \mathrm{C}(\mathrm{AcOEt}) ;{ }^{1} \mathrm{H}$ NMR (400 MHz, $\mathrm{CDCl}_{3}$ ) $\delta 2.29$ (ddd, J = 3.0, 8.2, $13.2 \mathrm{~Hz}, 1 \mathrm{H}$ ), 2.43-2.49 (m, 1H), 2.75 (dd, $\mathrm{J}=1.4,11.5 \mathrm{~Hz}, 1 \mathrm{H}), 3.33-3.38$ (m, 1H), 3.42-3.48 (m, 2H), 3.69 (d, J = 11.5 Hz, 1H),

\footnotetext{
${ }^{1}$ Perrin, D. D. and Armarego, W. L. F. Purification of Laboratory Chemicals; $3^{\text {rd }}$ ed., Pergamon Press, Oxford, 1988.
} 
3.82 (s, 3H), 4.29 (d, J = 14.8 Hz, 1H), 4.32 (dd, J = 4.4, 18.4 Hz, 1H), 4.53 (d, J = 14.8 Hz, 1H), 6.49 (dd, J = 1.9, $3.6 \mathrm{~Hz}, 1 \mathrm{H}$ ), 6.91 (d like, J = 8.6 Hz, 2H), 7.12 (dd, J = 2.2, 4.4 Hz, 1H), 7.15 (d, J = 3.6 Hz, 1H), 7.24 (d like, J = 8.6 Hz, 2H), 7.55-7.58 (m, 3H), 7.63-7.66 (m, 1H), 7.78-7.80 (m, 2H); ${ }^{13} \mathrm{C}$ NMR (100 MHz, $\mathrm{CDCl}_{3}$ ) $\delta$ 29.8, 43.7, 45.2, 46.6, 49.1, 50.2, 55.4, 112.2, 114.2, 119.9, 127.6, 128.0, 129.34. 129.37, 133.3, 135.4, 136.8, 138.4, 146.5, 151.9, 173.4, 180.2; IR (thin film) v 1680, 1637, 1510, 1338, 1247, 1165, $939 \mathrm{~cm}^{-1}$; LRMS (FAB) $\mathrm{m} / \mathrm{z} 507$ (M+H), 365; Anal. Calcd for $\mathrm{C}_{27} \mathrm{H}_{26} \mathrm{~N}_{2} \mathrm{O}_{6} \mathrm{~S}$ C: 64.02, H: 5.17, N: 5.53, Found C: 63.95, H: 5.22, N: 5.46.

\section{Synthesis of compound 8}

To a solution of 7 (2.5 g, $4.9 \mathrm{mmol})$ in $\mathrm{CH}_{3} \mathrm{CN}-\mathrm{H}_{2} \mathrm{O}(5: 2,140 \mathrm{~mL})$ was added CAN (8.1 g, $\left.14.8 \mathrm{mmol}\right)$ at room temperature. After stirring for $6 \mathrm{~h}$ at the same temperature, the mixture was extracted with $\mathrm{CH}_{2} \mathrm{Cl}_{2}$ and the combined organic layers were washed with water, dried over $\mathrm{Na}_{2} \mathrm{SO}_{4}$ and concentrated in vacuo. The residue was purified by flash column chromatography on silica gel (AcOEt) to afford the PMB deprotected product $\mathbf{S 1}$ as a<smiles>C[R5](=O)N1CC=C(C(=O)c2ccco2)C2(CCNC2=O)C1</smiles>

S1 colorless foam (1.3 g, 69\%): ${ }^{1} \mathrm{H}$ NMR (400 MHz, $\left.\mathrm{CDCl}_{3}\right) \delta$ 2.48-2.62 (m, 2H), 2.69 (dd, J $=1.5,11.5 \mathrm{~Hz}, 1 \mathrm{H}), 3.45$ (dd, $\mathrm{J}=2.3,18.6 \mathrm{~Hz}, 1 \mathrm{H}), 3.48-3.65(\mathrm{~m}, 2 \mathrm{H}), 3.78(\mathrm{~d}, \mathrm{~J}=11.5$ $\mathrm{Hz}, 1 \mathrm{H}$ ), 4.34 (dd, J = 4.5, 18.6 Hz, 1H), 6.01 (brs, 1H), 6.50 (dd, J = 1.7, 3.6 Hz, 1H), 7.16 (dd, $\mathrm{J}=0.7,3.6 \mathrm{~Hz}, 1 \mathrm{H}), 7.21$ (dd, $\mathrm{J}=2.3,4.5 \mathrm{~Hz}, 1 \mathrm{H}), 7.56-7.67(\mathrm{~m}, 4 \mathrm{H})$, 7.80-7.83 (m, 2H); ${ }^{13} \mathrm{C}$ NMR (100 MHz, $\mathrm{CDCl}_{3}$ ) $\delta 32.0$, 39.2, 45.1, 47.7, 50.0, 112.1, 119.7, 127.5, 129.4, 133.3, 135.3, 137.4, 137.9, 146.5, 152.0, 177.1, 180.0; IR (thin film) $v$ 3199, 1697, 1635, 1463, 1280, 1165, 936, $721 \mathrm{~cm}^{-1}$; LRMS (FAB) m/z 387 (M+H), 246; HRMS (FAB) $\mathrm{m} / \mathrm{z}$ Calcd for $\mathrm{C}_{19} \mathrm{H}_{19} \mathrm{~N}_{2} \mathrm{O}_{5} \mathrm{~S}(\mathrm{M}+\mathrm{H})$ 387.1015, Found 387.0988.

To a suspension of $\mathbf{S 1}(2.4 \mathrm{~g}, 6.2 \mathrm{mmol})$ and $\mathrm{CeCl}_{3} \cdot 7 \mathrm{H}_{2} \mathrm{O}(3.2 \mathrm{~g}, 18.6 \mathrm{mmol})$ in $\mathrm{MeOH}-\mathrm{THF}(4: 1,60 \mathrm{~mL})$ was added $\mathrm{NaBH}_{4}$ (710 mg, $\left.18.6 \mathrm{mmol}\right)$ at $0{ }^{\circ} \mathrm{C}$. After stirring for $1 \mathrm{~h}$ at ambient temperature, the reaction was quenched by addition of water. Solvent was removed in vacuo and the residue was extracted with AcOEt. The combined organic layers were washed with brine, dried over $\mathrm{Na}_{2} \mathrm{SO}_{4}$ and concentrated in vacuo to afford crude<smiles>O=C1NCC2(CCCCC2)C1C(O)C(O)c1ccco1</smiles>
secondary alcohol S2 as a colorless foam (1.5 g, 92\%) which was used to the next reaction without further purification: ${ }^{1} \mathrm{H}$ NMR $\left(400 \mathrm{MHz}, \mathrm{CDCl}_{3}\right) \delta 1.95-2.03(\mathrm{~m}, 1 \mathrm{H})$, 2.42 (ddd, $\mathrm{J}=1.7,7.8,13.2 \mathrm{~Hz}, 1 \mathrm{H}$ ), 2.61 (dd, $\mathrm{J}=1.3,11.1 \mathrm{~Hz}, 1 \mathrm{H}$ ), 3.18-3.27 (m, 2H), 3.43 (dd, J = 8.4, $17.8 \mathrm{~Hz}, 1 \mathrm{H}), 3.70$ (d, J = $11.1 \mathrm{~Hz}, 1 \mathrm{H}), 3.87$ (d, J = 7.6 Hz, 1H, disappeared by addition of $\left.\mathrm{D}_{2} \mathrm{O}\right), 4.12(\mathrm{dd}, \mathrm{J}=3.9,17.8 \mathrm{~Hz}, 1 \mathrm{H}), 5.32(\mathrm{~d}, \mathrm{~J}=7.6 \mathrm{~Hz}, 1 \mathrm{H})$, 5.69 (brs, 1H), 5.75 (brm, 1H), 6.30-6.35 (m, 2H), 7.38 (brm, 1H), 7.52-7.62 (m, 3H), 7.75 (d like, $\mathrm{J}=7.3 \mathrm{~Hz}, 2 \mathrm{H}) ;{ }^{13} \mathrm{C}$ NMR $\left(100 \mathrm{MHz}, \mathrm{CDCl}_{3}\right) \delta$ 31.4, 39.3, 44.8, 48.8, 49.7, 70.3, 107.6, 110.4, 125.2, 127.4, 129.2, 133.1, 135.5, 138.0, 141.9, 154.5, 178.6; IR (thin film) v 3347, 3238, 1683, 1445, 1347, 1169, 970, $754 \mathrm{~cm}^{-1}$; LRMS (FAB) $\mathrm{m} / \mathrm{z} 389(\mathrm{M}+\mathrm{H}), 371$; HRMS (FAB) $\mathrm{m} / \mathrm{z}$ Calcd for $\mathrm{C}_{19} \mathrm{H}_{20} \mathrm{~N}_{2} \mathrm{O}_{5} \mathrm{SNa}(\mathrm{M}+\mathrm{Na}) 411.0991$, Found 411.0971.

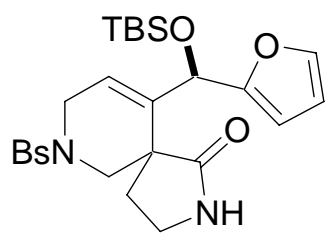

S3

To a solution of S2 (1.2 g, $3.0 \mathrm{mmol})$ and 2,6-lutidine (1.4 mL, $12 \mathrm{mmol})$ in $\mathrm{CH}_{2} \mathrm{Cl}_{2}$ was added TBSOTf $(1.4 \mathrm{~mL}, 6.0 \mathrm{mmol})$ at $0{ }^{\circ} \mathrm{C}$. After stirring for $30 \mathrm{~min}$ at the same temperature, the reaction was quenched by addition of water and extracted with $\mathrm{CH}_{2} \mathrm{Cl}_{2}$. The combined organic layers were washed with brine, dried over $\mathrm{Na}_{2} \mathrm{SO}_{4}$ and concentrated in vacuo. The crude product was roughly purified through a pad of silica 
gel (hexane:AcOEt = 1:1) to afford the TBS ether S3.

The crude S3 was dissolved in THF (30 mL) and added $\mathrm{Et}_{3} \mathrm{~N}(1.3 \mathrm{~mL}, 9.0 \mathrm{mmol}), \mathrm{Boc}_{2} \mathrm{O}(980 \mathrm{mg}, 4.5 \mathrm{mmol})$ and DMAP (73 mg, $0.6 \mathrm{mmol}$ ) at room temperature. After stirring for $12 \mathrm{~h}$ at the same temperature, the reaction was quenched by addition of water and extracted with AcOEt. The combined organic layers were washed with $1 \mathrm{~N}$ $\mathrm{HCl}, \mathrm{NaHCO}_{3}$ aq and brine, dried over $\mathrm{Na}_{2} \mathrm{SO}_{4}$ and concentrated in vacuo. The crude product was purified by flash column chromatography on silica gel (hexane:AcOEt $=3: 1$ ) to afford the compound 8 as a colorless foam

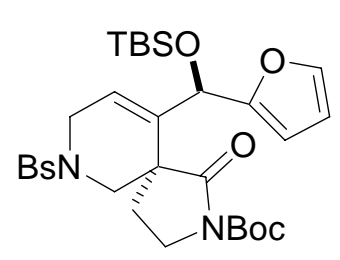

8

(1.3 g, 72\% in 2 steps): ${ }^{1} \mathrm{H}$ NMR (400 MHz, $\mathrm{CDCl}_{3}$ ) $\delta-0.27$ (s, 3H), -0.06 (s, 3H), 0.78 (s, 9H), 1.54 (s, 9H), 2.36 (ddd, J = 1.5, 7.6, $13.1 \mathrm{~Hz}, 1 \mathrm{H}$ ), 2.48 (dd, $\mathrm{J}=1.7,11.0 \mathrm{~Hz}, 1 \mathrm{H}$ ), 2.63-2.72 (m, 1H), 3.04 (ddd, $\mathrm{J}=$ 2.7, 3.1, $16.8 \mathrm{~Hz}, 1 \mathrm{H}$ ), 3.73-3.87 (m, 3H), 4.01 (ddd, $\mathrm{J}=$ 1.7, 3.9, $16.8 \mathrm{~Hz}, 1 \mathrm{H}), 5.04-5.06$ (m, 1H), 5.62-5.64 (m, 1H), 6.22 (dd, J = 0.7, 3.2 Hz, 1H), 6.31 (dd, J = 1.8, $3.2 \mathrm{~Hz}, 1 \mathrm{H}), 7.39$ (dd, J = 0.7, $1.8 \mathrm{~Hz}, 1 \mathrm{H}), 7.50-7.62$ (m, 3H), 7.72-7.75 (m, 2H); ${ }^{13} \mathrm{C}$ NMR (100 MHz, $\left.\mathrm{CD}_{3} \mathrm{OD}\right) \delta-5.10,-5.05,19.1,26.4,28.3,28.9,44.6,45.9,50.3,51.8$, 70.9, 84.1, 110.6, 111.3, 124.8, 128.7, 130.4, 134.4, 137.2, 138.8, 143.6, 151.5, 155.1, 175.4; IR (thin film) $v$ 2929, 1780, 1716, 1365, 1293, 1148, $835 \mathrm{~cm}^{-1}$; LRMS (FAB) m/z 641 (M+K), 541, 371, 230; HRMS (FAB) m/z Calcd for $\mathrm{C}_{30} \mathrm{H}_{42} \mathrm{~N}_{2} \mathrm{O}_{7} \mathrm{SSiK}(\mathrm{M}+\mathrm{K})$ 641.2119, Found 641.2170.

\section{Synthesis of compound 9}

To a solution of 8 (218 $\mathrm{mg}, 0.36 \mathrm{mmol})$ in THF $(5 \mathrm{~mL})$ was added $\mathrm{LiBEt}_{3} \mathrm{H}$ solution in THF $(1.0 \mathrm{M}, 1.1 \mathrm{~mL}$, $1.1 \mathrm{mmol})$ at $-78{ }^{\circ} \mathrm{C}$. After stirring for $2 \mathrm{~h}$ at $-78{ }^{\circ} \mathrm{C}$, the reaction was quenched by addition of water. Solvent was

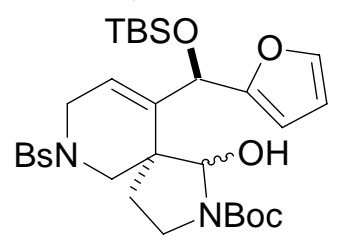

9 removed in vacuo and the residue was extracted with AcOEt. The combined organic layers were washed with water and brine, dried over $\mathrm{Na}_{2} \mathrm{SO}_{4}$ and concentrated in vacuo. The crude product was purified by flash column chromatography on silica gel (hexane:AcOEt $=3: 1$ ) to afford the hemiaminal 9 as a colorless foam (210 mg, 96\%). This compound was immediately used to the next reaction.

\section{Synthesis of compound 10}

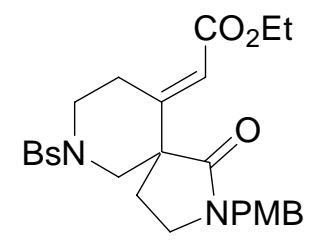

S4

To a solution of 5 (10 g, $23 \mathrm{mmol})$ in toluene $(160 \mathrm{~mL})$ was added (Carbethoxymethylene)triphenylphosphorane $(41 \mathrm{~g}, 117 \mathrm{mmol}$ ) and stirred for $12 \mathrm{~h}$ at $100{ }^{\circ} \mathrm{C}$. The mixture was concentrated in vacuo to give a residue which was purified by flash column chromatography on silica gel (hexane:AcOEt $=3: 2$ ) to afford the ester $\mathbf{S} \mathbf{4}$ as a colorless solid (11 g, 91\%): mp $155{ }^{\circ} \mathrm{C}$ (hexane-AcOEt); ${ }^{1} \mathrm{H}$ NMR (400 MHz, $\left.\mathrm{CDCl}_{3}\right) \delta$ 1.23 (t, $\mathrm{J}=7.2 \mathrm{~Hz}, 3 \mathrm{H}$ ), 2.11 (ddd, $\mathrm{J}=3.4,7.8,13.2 \mathrm{~Hz}, 1 \mathrm{H}), 2.33-2.41(\mathrm{~m}, 3 \mathrm{H}), 2.76$ (d, J = $11.6 \mathrm{~Hz}, 1 \mathrm{H}$ ), 3.13-3.25 (m, 2H), 3.64 (dd, J = 2.0, 11.6 Hz, 1H), 3.80 (s, 3H), 3.90 (brm, 1H), 4.01-4.12 (m, 3H), 4.40 (d, J = $14.6 \mathrm{~Hz}, 1 \mathrm{H}$ ), 4.49 (d, J = 14.6 Hz, 1H), 5.64 (s, 1H), 6.88 (d like, J = 8.4 Hz, 2H), 7.19 (d like, J = 8.4 Hz, 2H),

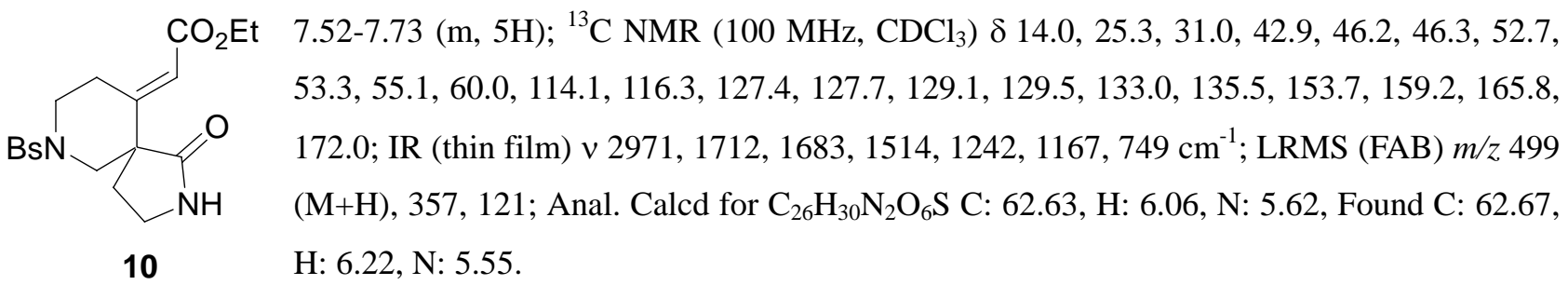


To a solution of $\mathbf{S} 4(2.7 \mathrm{~g}, 5.4 \mathrm{mmol})$ in $\mathrm{CH}_{3} \mathrm{CN}-\mathrm{H}_{2} \mathrm{O}(5: 2,54 \mathrm{~mL})$ was added CAN (8.9 g, $\left.16.2 \mathrm{mmol}\right)$ at room temperature. After stirring for $6 \mathrm{~h}$ at the same temperature, the mixture was extracted with $\mathrm{CH}_{2} \mathrm{Cl}_{2}$ and the combined organic layers were washed with water, dried over $\mathrm{Na}_{2} \mathrm{SO}_{4}$ and concentrated in vacuo. The residue was dissolved in $\mathrm{CH}_{2} \mathrm{Cl}_{2}(40 \mathrm{~mL})$ and added $70 \% \mathrm{HClO}_{4}(13 \mathrm{~mL})$ at room temperature. After stirring for $2 \mathrm{~h}$ at the same temperature, the reaction mixture was poured into $\mathrm{NaHCO}_{3}$ aq and extracted with $\mathrm{CH}_{2} \mathrm{Cl}_{2}$. The combined organic layers were dried over $\mathrm{Na}_{2} \mathrm{SO}_{4}$ and concentrated in vacuo to give a residue which was purified by flash column chromatography on silica gel (hexane:AcOEt $=2: 3$ ) to afford the PMB deprotected product $\mathbf{1 0}$ as a colorless solid (1.8 g, 87\%): mp $184{ }^{\circ} \mathrm{C}$ (hexane- $\mathrm{CH}_{2} \mathrm{Cl}_{2}$ ); ${ }^{1} \mathrm{H}$ NMR (400 MHz, $\left.\mathrm{CDCl}_{3}\right) \delta 1.22(\mathrm{t}, \mathrm{J}=7.1 \mathrm{~Hz}, 3 \mathrm{H}$ ), 2.24-2.44 (m, 3H), 2.58 (ddd, J = 7.3, 8.4, 13.4 Hz, 1H), 2.70 (d, J = 11.7 Hz, 1H), 3.29-3.46 (m, 2H), 3.68 (dd, J = 2.3, $11.7 \mathrm{~Hz}, 1 \mathrm{H}), 3.90-4.14$ (m, 4H), 5.78 (brs, $1 \mathrm{H}), 5.87$ (brs, $1 \mathrm{H}), 7.51-7.74$ (m, 5H); ${ }^{13} \mathrm{C} \mathrm{NMR}(100 \mathrm{MHz}$, $\left.\mathrm{CDCl}_{3}\right) \delta 14.1,25.4,33.5,38.7,46.5,51.7,53.1,60.2,116.4,127.5,129.2,133.1,135.6,153.4,165.9,176.0$; IR (thin film) $\vee$ 3191, 2857, 1715, 1691, 1648, 1222, 1164, $692 \mathrm{~cm}^{-1}$; LRMS (FAB) $\mathrm{m} / \mathrm{z} 379$ (M+H), 333, 237; HRMS (FAB) $\mathrm{m} / \mathrm{z}$ Calcd for $\mathrm{C}_{18} \mathrm{H}_{23} \mathrm{~N}_{2} \mathrm{O}_{5} \mathrm{~S}(\mathrm{M}+\mathrm{H})$ 379.1328, Found 379.1313; Anal. Calcd for $\mathrm{C}_{18} \mathrm{H}_{22} \mathrm{~N}_{2} \mathrm{O}_{5} \mathrm{~S}$ C: 57.13, H: 5.86, N: 7.40, Found C: 56.69, H: 5.90, N: 7.24.

\section{Synthesis of compound $\mathbf{1 1}$}

To a solution of 10 (4.4 g, $12 \mathrm{mmol})$ in $\mathrm{MeOH}-\mathrm{H}_{2} \mathrm{O}(4: 1,220 \mathrm{~mL})$ was added $\mathrm{PtO}_{2}(220 \mathrm{mg})$ and the mixture was stirred under $\mathrm{H}_{2}$ atmosphere for $6 \mathrm{~h}$ at room temperature. The mixture was filtered through a pad of Celite ${ }^{\circledR}$ and concentrated in vacuo. The residue was extracted with AcOEt and the combined organic layers were washed with brine, dried over $\mathrm{Na}_{2} \mathrm{SO}_{4}$ and concentrated in vacuo to give the crude hydrogenated product $\mathbf{1 1}$ as a colorless solid (4.0 g, 92\%, dr = 15:1) which was used to the next reaction without further purification: $\mathrm{mp} 176{ }^{\circ} \mathrm{C}$

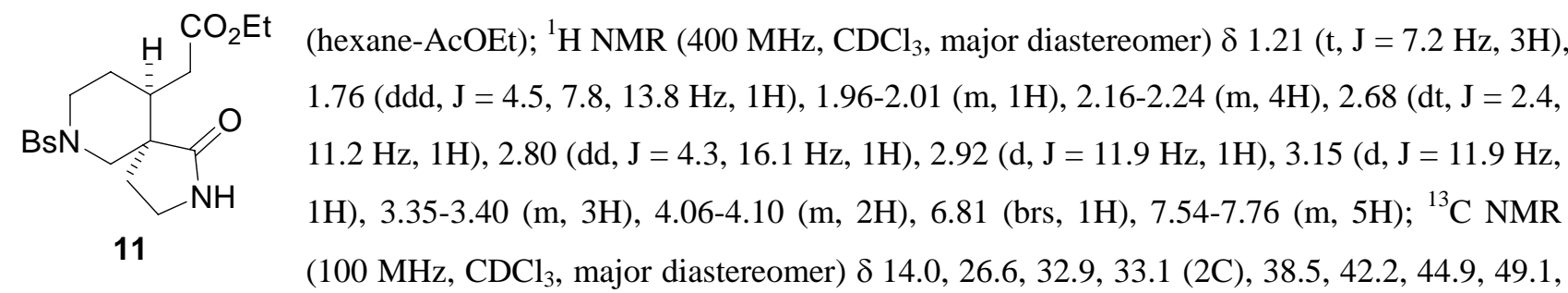
60.4, 127.4, 129.1, 132.8, 136.0, 172.3, 177.9; IR (thin film) $v$ 3211, 2856, 1732, 1685, 1335, 1166, $766 \mathrm{~cm}^{-1}$; LRMS (FAB) m/z $381(\mathrm{M}+\mathrm{H})$, 239; Anal. Calcd for $\mathrm{C}_{18} \mathrm{H}_{24} \mathrm{~N}_{2} \mathrm{O}_{5}$ S C: 56.82, H: 6.36, N: 7.36, Found C: 56.73, H: 6.37, N: 7.22 .

\section{Synthesis of compound 12}

To a suspension of $\mathbf{1 1}(2.0 \mathrm{~g}, 5.3 \mathrm{mmol})$ and $\mathrm{HNMe}(\mathrm{OMe}) \cdot \mathrm{HCl}(780 \mathrm{mg}, 7.9 \mathrm{mmol})$ in THF $(120 \mathrm{~mL})$ was added $2.0 \mathrm{M}$ solution $\mathrm{PrMgCl}$ in THF $(11 \mathrm{~mL}, 22 \mathrm{mmol})$ at $-20^{\circ} \mathrm{C}$. After stirring for $2 \mathrm{~h}$ at ambient temperature, the reaction was quenched by addition of $\mathrm{H}_{2} \mathrm{O}$ and concentrated in vacuo. The residue was extracted with AcOEt

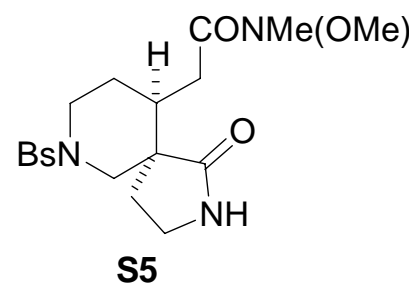

and the combined organic layers were washed with brine, dried over $\mathrm{Na}_{2} \mathrm{SO}_{4}$ and concentrated in vacuo. The crude Weinreb amide S5 was obtained as a colorless solid (2.1 g, quant) and was used to the next reaction without further purification: mp $186{ }^{\circ} \mathrm{C}\left(\mathrm{iPr}_{2} \mathrm{O}-\mathrm{CH}_{2} \mathrm{Cl}_{2}\right) ;{ }^{1} \mathrm{H} \mathrm{NMR}\left(400 \mathrm{MHz}, \mathrm{CDCl}_{3}\right.$, major diastereomer) $\delta 1.76$ (ddd, $\mathrm{J}=4.2,7.7,14.1 \mathrm{~Hz}, 1 \mathrm{H}), 1.96-2.04(\mathrm{~m}, 1 \mathrm{H}), 2.20-2.41$ (m, 4H), 2.69 (dt, $\mathrm{J}=$ 
3.0, 11.3 Hz, 1H), 2.88 (dd, J = 3.9, 16.0 Hz, 1H), 2.96 (d, J = $12.2 \mathrm{~Hz}, 1 \mathrm{H}$ ), 3.12 (s, 3H), 3.20 (d, J = 12.2 Hz, 1H), 3.33-3.45 (m, 3H), 3.60 (s, 3H), 5.54 (brs, 1H), 7.53-7.78 (m, 5H); ${ }^{13} \mathrm{C}$ NMR (100 MHz, CDCl 3 , $55{ }^{\circ} \mathrm{C}$, major diastereomer) $\delta$ 27.0, 30.6, 32.4 (br), 32.8, 33.2, 38.4, 42.7, 45.0, 49.6, 61.1, 127.6, 129.1, 132.6, 137.0, 172.9, 177.7; IR (thin film) v 3201, 2850, 1679, 1650, 1352, 1169, 747, $688 \mathrm{~cm}^{-1}$; LRMS (FAB) $\mathrm{m} / \mathrm{z} 396(\mathrm{M}+\mathrm{H})$, 335, 254; Anal. Calcd for $\mathrm{C}_{18} \mathrm{H}_{25} \mathrm{~N}_{3} \mathrm{O}_{5}$ S C: 54.67, H: 6.37, N: 10.63, Found C: 54.47, H: 6.42, N: 10.56 .

A solution of $n$-butyllithium in hexane $(1.59 \mathrm{M}, 11 \mathrm{~mL}, 18 \mathrm{mmol}$ ) was added to a solution of furan (freshly distilled from Na) $(1.4 \mathrm{~mL}, 19 \mathrm{mmol})$ in THF $(19 \mathrm{~mL})$ at $0{ }^{\circ} \mathrm{C}$. The reaction mixture was warmed to room temperature and stirred for further $30 \mathrm{~min}$. This 2-furyllithium solution was added to a solution of S5 (2.1 g, 5.3 $\mathrm{mmol})$ in THF $(100 \mathrm{~mL})$ via a syringe at $-78{ }^{\circ} \mathrm{C}$. After stirring for $2 \mathrm{~h}$ at the same temperature, the mixture was quenched by addition of $\mathrm{H}_{2} \mathrm{O}$ and concentrated in vacuo. The residue was extracted with AcOEt and the combined organic layers were washed with brine, dried over $\mathrm{Na}_{2} \mathrm{SO}_{4}$ and concentrated in vacuo. The residue was purified by flash column chromatography on silica gel (AcOEt) to afford the 2-furylketone $\mathbf{1 2}$ as a colorless solid (1.8 g,

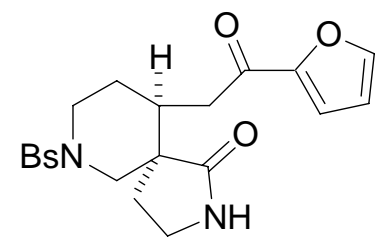

12

87\%). Minor diastereomer was removed by recrystallization from $\mathrm{CH}_{2} \mathrm{Cl}_{2}$ - $\mathrm{AcOEt}$ (about $70 \%$ recovery): $\mathrm{mp} 214-215{ }^{\circ} \mathrm{C}\left(\mathrm{CH}_{2} \mathrm{Cl}_{2}\right.$-AcOEt); ${ }^{1} \mathrm{H}$ NMR $\left(400 \mathrm{MHz}, \mathrm{CDCl}_{3}\right)$ $\delta 1.77$ (ddd, $\mathrm{J}=4.4,7.8,14.1 \mathrm{~Hz}, 1 \mathrm{H}), 1.98-2.06(\mathrm{~m}, 1 \mathrm{H}), 2.29(\mathrm{t}, \mathrm{J}=6.8 \mathrm{~Hz}, 2 \mathrm{H}$ ), 2.51-2.56 (m, 1H), 2.66-2.73 (m, 2H), 3.00 (d, J = 12.2 Hz, 1H), 3.24 (d, J = $12.2 \mathrm{~Hz}$, 1H), 3.36-3.48 (m, 4H), 5.55 (brs, 1H), 6.48 (dd, J = 1.7, 3.7 Hz, 1H), 7.12 (d, J = 3.7

$\mathrm{Hz}, 1 \mathrm{H}), 7.52-7.79$ (m, 6H); ${ }^{13} \mathrm{C}$ NMR (100 MHz, $\left.\mathrm{CDCl}_{3}\right) \delta$ 27.0, 31.5, 33.1, 36.8, 38.5, 42.5, 44.9, 49.4, 112.2, 117.0, 127.5, 129.2, 132.8, 136.3, 146.3, 152.6, 177.9, 187.5; IR (thin film) v 3296, 3116, 2855, 1689, 1659, 1469, 1328, 1162, $754 \mathrm{~cm}^{-1}$; LRMS (FAB) $\mathrm{m} / \mathrm{z} 403(\mathrm{M}+\mathrm{H})$; Anal. Calcd for $\mathrm{C}_{20} \mathrm{H}_{22} \mathrm{~N}_{2} \mathrm{O}_{6} \mathrm{~S}$ C: 59.69, H: 5.51, N: 6.96, Found C: 59.32, H: 5.56, N: 6.84.

\section{Synthesis of compound $\mathbf{1 3}$}

To a solution of 12 (2.0 g, $5.0 \mathrm{mmol})$ in MeOH-THF (4:1, $36 \mathrm{~mL})$ was added $\mathrm{NaBH}_{4}(570 \mathrm{mg}, 15 \mathrm{mmol})$ at $0{ }^{\circ} \mathrm{C}$. After stirring for $1 \mathrm{~h}$ at ambient temperature, the mixture was quenched by addition of $\mathrm{H}_{2} \mathrm{O}$ and concentrated

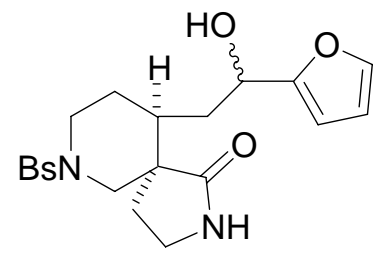

S6

in vacuo. The residue was extracted with AcOEt and the combined organic layers were washed with brine, dried over $\mathrm{Na}_{2} \mathrm{SO}_{4}$ and concentrated in vacuo. The crude secondary alcohol $\mathbf{S 6}$ was obtained as a colorless foam $(2.0 \mathrm{~g}, 99 \%, \mathrm{dr}=1: 1)$ and was used to the next reaction without further purification: ${ }^{1} \mathrm{H}$ NMR $\left(400 \mathrm{MHz}, \mathrm{CDCl}_{3}\right) \delta 1.65-1.72(\mathrm{~m}$, $2 \mathrm{H}), 1.83-1.90(\mathrm{~m}, 2 \mathrm{H}), 2.13-2.41(\mathrm{~m}, 4 \mathrm{H}), 2.77-2.88(\mathrm{~m}, 1 \mathrm{H}), 3.01-3.14(\mathrm{~m}, 2 \mathrm{H})$, 3.23-3.37 (m, 3H), 4.59-4.62 (m, 0.5H), 4.68 (brm, 0.5H), 5.88 (brs, 0.5H), 5.92 (brs, 0.5H), 6.18-6.20 (m, 1H), 6.28-6.29 (m, 1H), 7.31-7.32 (m, 1H), 7.51-7.78 (m, 5H); ${ }^{13} \mathrm{C}$ NMR (100 MHz, $\mathrm{CDCl}_{3}$ ) $\delta$ 26.3, 27.4, 32.9, 33.0, 33.7, 33.8, 33.98, 34.01, 38.43, 38.46, 42.8, 43.0, 45.19, 45.21, 49.4, 49.7, 65.7, 66.9, 105.8, 106.3, 110.2, 110.3, 127.6 (2C), 129.2 (2C), 132.8 (2C), 136.25. 136.31, 141.93, 141.95, 156.0, 156.6, 178.2; IR (thin film) v 3387, 2934, 1684, 1332, 1162, $749 \mathrm{~cm}^{-1}$; LRMS (EI) m/z 404 (M), 386, 252, 245, 219, 151; HRMS (FAB) m/z Calcd for $\mathrm{C}_{20} \mathrm{H}_{24} \mathrm{~N}_{2} \mathrm{O}_{5} \mathrm{~S}(\mathrm{M}+\mathrm{H})$ 405.1484, Found 405.1464.

To a solution of $\mathbf{S 6}$ (2.0 g, $5.0 \mathrm{mmol})$ and imidazole $(1.4 \mathrm{~g}, 20 \mathrm{mmol})$ in DMF (50 mL) was added TBDMSCl (1.5 g, $10 \mathrm{mmol}$ ) at room temperature. After stirring for $3 \mathrm{~h}$ at the same temperature, the mixture was quenched by addition of $\mathrm{H}_{2} \mathrm{O}$ and extracted with AcOEt and the combined organic layers were washed with $1 \mathrm{~N} \mathrm{HCl}$, water and 
brine, dried over $\mathrm{Na}_{2} \mathrm{SO}_{4}$ and concentrated in vacuo. The residue was purified by flash column chromatography on silica gel (hexane:AcOEt = 2:3) to afford the TBS ether $\mathbf{S 7}$ as a colorless foam (2.3 g, 89\%): ${ }^{1} \mathrm{H}$ NMR (400 MHz, $\left.\mathrm{CDCl}_{3}\right) \delta-0.19$ (s, 1.5H), $-0.16(\mathrm{~s}, 1.5 \mathrm{H}),-0.03$ (s, 1.5H), -0.02 (s, 1.5H), 0.81 (s, 4.5H), 0.83 (s, 4.5H), 1.55-2.08 (m, 5H), 2.20-2.26 (m, 2H), 2.83-3.03 (m, 2H), 3.08-3.37 (m, 4H), 4.62-4.68 (m, 1H), 5.84 (brs, 0.5H), 5.85 (brs, 0.5H), 6.10-6.13 (m, 1H), 6.25-6.27 (m, 1H), 7.28-7.29 (m, 1H), 7.50-7.61 (m, 3H), 7.75-7.80 (m, 2H);

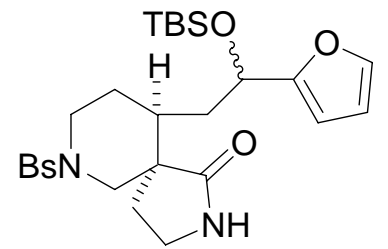

S7

${ }^{13} \mathrm{C}$ NMR $\left(100 \mathrm{MHz}, \mathrm{CDCl}_{3}\right) \delta-5.36,-5.25,-5.12,-5.07,18.0,18.1,25.5,25.69$, 25.70, 27.3, 32.8 (2C), 33.9, 34.1, 34.9, 35.4, 38.5, 38.6, 43.3, 43.5, 45.0, 45.2, 50.1, 50.5, 66.1, 67.5, 106.1, 106.2, 110.00, 110.03, 127.54, 127.57, 129.1 (2C), 132.7 (2C), 136.3, 136.5, 141.28, 141.30, 156.3, 156.5, 178.0, 178.1; IR (thin film) v 2932, 1691, 1335, 1252, 1166, 929, 835, $748 \mathrm{~cm}^{-1}$; LRMS (FAB) m/z 557 (M+K), 387; HRMS (FAB) $m / z$ Calcd for $\mathrm{C}_{26} \mathrm{H}_{38} \mathrm{~N}_{2} \mathrm{O}_{5} \mathrm{SSiK}(\mathrm{M}+\mathrm{K})$ 557.1908, Found 557.1866.

To a solution of $\mathbf{S} 7(2.0 \mathrm{~g}, 3.9 \mathrm{mmol})$ and $\mathrm{Et}_{3} \mathrm{~N}(2.6 \mathrm{~mL}, 20 \mathrm{mmol})$ in THF $(40 \mathrm{~mL})$ was added $\mathrm{Boc}_{2} \mathrm{O}(1.6 \mathrm{~g}, 12$ mmol) and DMAP (100 mg, $0.8 \mathrm{mmol}$ ) at room temperature. After stirring for $6 \mathrm{~h}$ at the same temperature, the mixture was quenched by addition of $\mathrm{H}_{2} \mathrm{O}$ and extracted with AcOEt. The combined organic layers were washed with $1 \mathrm{~N} \mathrm{HCl}$, brine, dried over $\mathrm{Na}_{2} \mathrm{SO}_{4}$ and concentrated in vacuo. The residue was purified by flash column chromatography on silica gel (hexane:AcOEt = 2:1) to afford the Boc lactam S8 as a colorless foam (2.2 g, 91\%):

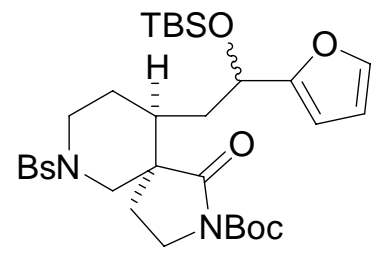

S8

${ }^{1} \mathrm{H}$ NMR $\left(400 \mathrm{MHz}, \mathrm{CDCl}_{3}\right) \delta-0.19$ (s, $\left.1.5 \mathrm{H}\right),-0.18$ (s, $\left.1.5 \mathrm{H}\right),-0.034$ (s, $\left.1.5 \mathrm{H}\right)$, -0.031 (s, 1.5H), 0.81 (s, 4.5H), 0.82 (s, 4.5H), 1.53 (s, 4.5H), 1.54 (s, 4.5H), 1.50-1.96 (m, 5H), 2.08-2.13 (m, 2H), 2.73-2.79 (m, 0.5H), 2.86-2.92 (m, 0.5H), 3.01-3.05 (m, 1.5H), 3.15-3.23 (m, 1.5H), 3.54-3.60 (m, 1H), 3.67-3.75 (m, 1H), 4.56-4.65 (m, 1H), 6.10-6.12 (m ,1H), 6.25-6.27 (m, 1H), 7.28-7.29 (m, 1H), 7.51-7.62 (m, 3H), 7.73-7.77 (m, 2H); ${ }^{13} \mathrm{C}$ NMR (100 MHz, $\left.\mathrm{CDCl}_{3}\right) \delta-5.35,-5.24,-5.18,-5.07,17.99,18.04,25.4,25.7,27.0,28.0,29.0$ (2C), 33.0, 33.2, 34.6, 35.2, 42.5, 42.6, 42.8, 43.0, 48.0, 48.2, 49.6, 49.9, 66.2, 67.4, 83.0, 83.1, 106.3 (2C), 110.05, 110.11, 127.5, 127.6, 129.1 (2C), 132.9 (2C), 136.2, 136.4, 141.3, 141.4, 149.99, 150.02, 156.1, 156.2, 173.7, 173.8; IR (thin film) v 3754, 2933, 1779, 1715, 1309, 1150, 835, 774, $742 \mathrm{~cm}^{-1}$; LRMS (FAB) m/z 657 (M+K), 541, 387; HRMS (FAB) m/z Calcd for $\mathrm{C}_{31} \mathrm{H}_{46} \mathrm{~N}_{2} \mathrm{O}_{7} \mathrm{SSiK}(\mathrm{M}+\mathrm{K}$ ) 657.2432, Found 657.2424.

To a solution of $\mathbf{S 8}(1.2 \mathrm{~g}, 1.9 \mathrm{mmol})$ in THF $(20 \mathrm{~mL})$ was added $\mathrm{LiBEt}_{3} \mathrm{H}$ solution in THF (1.0 M, 5.6 mL, 5.6 mmol) at $-78{ }^{\circ} \mathrm{C}$. After stirring for $3 \mathrm{~h}$ at $-78{ }^{\circ} \mathrm{C}$, the reaction was quenched by addition of water. Solvent was removed in vacuo and the residue was extracted with AcOEt. The combined organic layers were washed with

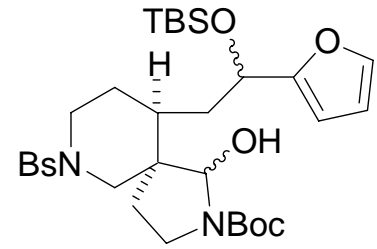

13 water and brine, dried over $\mathrm{Na}_{2} \mathrm{SO}_{4}$ and concentrated in vacuo. The residue was purified by flash column chromatography on silica gel (hexane:AcOEt $=2: 1$ ) to afford the hemiaminal 13 as a colorless foam (1.0 g, 87\%). This compound was immediately used to the next reaction.

\section{Synthesis of compound 14}

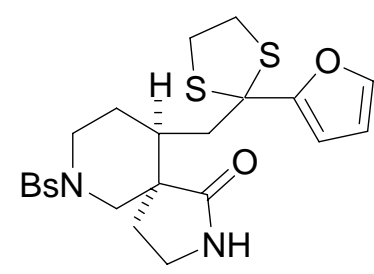

S9

To a solution of 12 (940 mg, $2.3 \mathrm{mmol})$ and 1,2-ethanedithiol (2.0 mL, $23 \mathrm{mmol})$ in $\mathrm{CH}_{2} \mathrm{Cl}_{2}(25 \mathrm{~mL})$ was added $\mathrm{BF}_{3} \cdot \mathrm{OEt}_{2}(1.5 \mathrm{~mL}, 12 \mathrm{mmol})$ at room temperature. After stirring for $24 \mathrm{~h}$ at the same temperature, the mixture was concentrated in vacuo. The residue was roughly purified by flash column chromatography on silica gel 
(hexane:AcOEt $=1: 2$ ) to afford the thioketal S9 as a colorless foam (860 mg, 78\%). This compound was immediately used to the next reaction.

To a solution of $\mathbf{S 9}(920 \mathrm{mg}, 1.9 \mathrm{mmol})$ and $\mathrm{Et}_{3} \mathrm{~N}(1.1 \mathrm{~mL}, 7.7 \mathrm{mmol})$ in THF $(20 \mathrm{~mL})$ was added $\mathrm{Boc}_{2} \mathrm{O}(840$ $\mathrm{mg}, 3.9 \mathrm{mmol}$ ) and DMAP (47 mg, $0.39 \mathrm{mmol}$ ) at room temperature. After stirring for $6 \mathrm{~h}$ at the same temperature, the mixture was quenched by addition of $\mathrm{H}_{2} \mathrm{O}$ and extracted with AcOEt. The combined organic layers were washed with $1 \mathrm{~N} \mathrm{HCl}$ and brine, dried over $\mathrm{Na}_{2} \mathrm{SO}_{4}$ and concentrated in vacuo. The residue was purified by flash column chromatography on silica gel (hexane:AcOEt = 2:1) to afford the Boc lactam S10 as a colorless foam (910

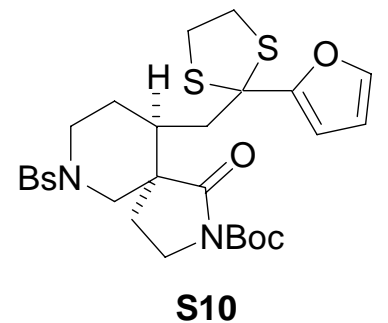
mg, 82\%): ${ }^{1} \mathrm{H}$ NMR (400 MHz, $\mathrm{CDCl}_{3}$ ) $\delta$ 1.49-1.57 (m, 1H), 1.53 (s, 9H), 1.75 (brm, $2 \mathrm{H}), 1.90-1.98(\mathrm{~m}, 1 \mathrm{H}), 2.15-2.23(\mathrm{~m}, 2 \mathrm{H}), 2.53-2.58(\mathrm{~m}, 1 \mathrm{H}), 2.64(\mathrm{~d}, \mathrm{~J}=14.8 \mathrm{~Hz}$, 1H), 2.81 (d, J = 12.1 Hz, 1H), 3.19-3.41 (m, 6H), 3.58-3.75 (m, 2H), 6.23 (dd, J = 1.8, $3.3 \mathrm{~Hz}, 1 \mathrm{H}), 6.33$ (dd, $\mathrm{J}=0.6,3.3 \mathrm{~Hz}, 1 \mathrm{H}), 7.30-7.31(\mathrm{~m}, 1 \mathrm{H}), 7.52-7.73(\mathrm{~m}, 5 \mathrm{H}) ;{ }^{13} \mathrm{C}$ NMR $\left(100 \mathrm{MHz}, \mathrm{CDCl}_{3}\right) \delta 27.1,28.1,29.5,34.4,38.4,38.8,39.8,42.7,42.8,48.8$, 50.0, 67.0, 82.8, 107.9, 110.4, 127.6, 129.2, 133.0, 136.0, 142.4, 150.1, 155.8, 174.2; IR (thin film) v 2932, 1773, 1714, 1293, 1149, 913, $727 \mathrm{~cm}^{-1}$; LRMS (FAB) $\mathrm{m} / \mathrm{z} 617$ (M+K), 517, 479, 291; HRMS (FAB) $m / z$ Calcd for $\mathrm{C}_{27} \mathrm{H}_{34} \mathrm{~N}_{2} \mathrm{O}_{6} \mathrm{~S}_{3} \mathrm{~K}(\mathrm{M}+\mathrm{K})$ 617.1216, Found 617.1201.

To a solution of $\mathbf{S 1 0}(910 \mathrm{mg}, 1.6 \mathrm{mmol})$ in THF $(20 \mathrm{~mL})$ was added $\mathrm{LiBEt}_{3} \mathrm{H}$ solution in THF (1.0 M, $4.7 \mathrm{~mL}$, $4.7 \mathrm{mmol}$ ) at $-78{ }^{\circ} \mathrm{C}$. The mixture was warmed to $0{ }^{\circ} \mathrm{C}$ and stirred for $5 \mathrm{~h}$ at the same temperature. The reaction

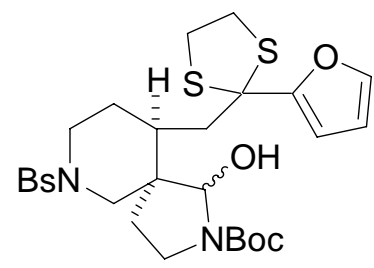

14 was quenched by addition of water and the solvent was removed in vacuo. The residue was extracted with AcOEt and the combined organic layers were washed with water and brine, dried over $\mathrm{Na}_{2} \mathrm{SO}_{4}$ and concentrated in vacuo. The crude product was purified by flash column chromatography on silica gel (hexane:AcOEt $=2: 1$ ) to afford the hemiaminal 14 as a colorless foam (710 mg, 78\%). This compound was immediately used to the next reaction.

Synthesis of compound 15 by furan-iminium cation cyclization

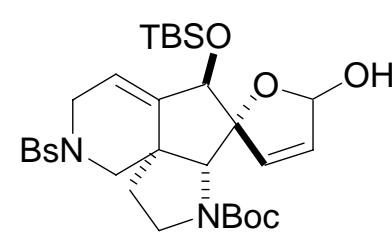

15

To a solution of 9 (210 mg, $0.35 \mathrm{mmol})$ in toluene $(8 \mathrm{~mL})$ was added AcOH $(2 \mathrm{~mL})$ at room temperature. After stirring for $72 \mathrm{~h}$ at the same temperature, the reaction was quenched by addition of $\mathrm{NaHCO}_{3}$ aq. The mixture was extracted with AcOEt and the combined organic layers were washed with $\mathrm{NaHCO}_{3}$ aq, dried over $\mathrm{Na}_{2} \mathrm{SO}_{4}$ and concentrated in vacuo. The residue was purified by flash column chromatography on silica gel (hexane:AcOEt $=3: 1$ ) to afford the cyclized lactol 15 as a colorless foam (170 mg, 80\%): $\mathrm{mp}$ 191-192 ${ }^{\circ} \mathrm{C}$ (dec., $\left.i \mathrm{Pr}_{2} \mathrm{O}\right) ;{ }^{1} \mathrm{H}$ NMR $\quad\left(400 \mathrm{MHz}, \mathrm{CDCl}_{3}\right) \delta 0.01$ (s, 3H), 0.03 (s, 3H), 0.84 (s, 9H), 1.48 (s, 9H), 1.93-2.00 (m, 1H), 2.19 (d, J = 11.2 Hz, 1H), 2.29-2.35 (m, 1H), 3.15 (dt, J = 16.4, 2.8 Hz, 1H), 3.60-3.65 (m, 2H), 3.69 (s, 1H), 3.84 (d, J = 11.2 Hz, 1H), 4.16 (dt, J = 16.4, 3.6 Hz, 1H), 4.67-4.68 (m, 1H), 4.86 (d, J = 12.0 Hz, 1H, disappeared by addition of $\left.\mathrm{D}_{2} \mathrm{O}\right), 5.53-5.56(\mathrm{~m}, 1 \mathrm{H}), 5.70(\mathrm{~d}, \mathrm{~J}=5.6 \mathrm{~Hz}, 1 \mathrm{H}), 5.79(\mathrm{~d}, \mathrm{~J}=5.6 \mathrm{~Hz}, 1 \mathrm{H}), 5.89(\mathrm{~d}, \mathrm{~J}=$ $12.0 \mathrm{~Hz}, 1 \mathrm{H}$, to be singlet by addition of $\left.\mathrm{D}_{2} \mathrm{O}\right), 7.54-7.65(\mathrm{~m}, 3 \mathrm{H}), 7.78-7.80(\mathrm{~m}, 2 \mathrm{H})$; ${ }^{13} \mathrm{C}$ NMR $(100 \mathrm{MHz}$, $\left.\mathrm{CDCl}_{3}\right) \delta-5.0,-4.8,18.2,25.8,28.5,35.9,45.0,46.9,48.3,51.7,68.9,77.5,81.2,95.6,104.7,114.0,127.5$, 128.8, 129.3, 133.1, 133.4, 136.2, 141.7, 157.0; IR (thin film) v 3317, 2860, 1661, 1396, 1164, 1067, $867 \mathrm{~cm}^{-1}$; LRMS (FAB) m/z 643 (M+K), 587, 487; Anal. Calcd for $\mathrm{C}_{30} \mathrm{H}_{44} \mathrm{~N}_{2} \mathrm{O}_{7}$ SSi C: 59.57, H: 7.33, N: 4.63, Found C: 
59.62, H: 7.28, N: 4.60.

\section{Synthesis of compound 16}

To a solution of 15 (150 mg, $0.25 \mathrm{mmol})$ in $\mathrm{MeOH}(5 \mathrm{~mL})$ was added $\mathrm{NaBH}_{4}(140 \mathrm{mg}, 3.8 \mathrm{mmol})$ at $0{ }^{\circ} \mathrm{C}$. The mixture was warmed to room temperature and stirred for $6 \mathrm{~h}$ at the same temperature. The reaction was quenched by addition of $\mathrm{H}_{2} \mathrm{O}$. The mixture was extracted with AcOEt and the combined organic layers were washed with water and brine, dried over $\mathrm{Na}_{2} \mathrm{SO}_{4}$ and concentrated in vacuo. The crude diol was dissolved in THF (5 mL) and added a 1.0 M TBAF solution in THF $(0.75 \mathrm{~mL}, 0.75 \mathrm{mmol})$ at $0{ }^{\circ} \mathrm{C}$. After stirring for $30 \mathrm{~min}$, the reaction was quenched with water. The mixture was extracted with AcOEt and the combined organic layers were washed with water and brine, dried over $\mathrm{Na}_{2} \mathrm{SO}_{4}$ and concentrated in vacuo. The residue was purified by flash column chromatography on silica gel (AcOEt) to afford the triol $\mathbf{1 6}$ as a colorless solid (104 $\mathrm{mg}, \mathbf{8 5 \%}$ in $2 \mathrm{steps}$ ): $\mathrm{mp}$

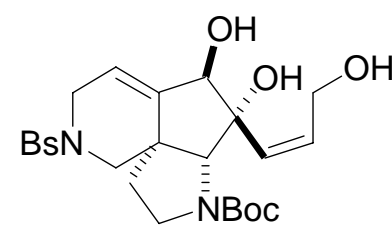

16 137-140 ${ }^{\circ} \mathrm{C}$ (dec., hexane-acetone); ${ }^{1} \mathrm{H}$ NMR (400 MHz, $\left.\mathrm{CDCl}_{3}\right) \delta 1.49$ (s, 9H), 1.94-2.01 (m, 1H), 2.22-2.30 (m, 2H), $3.18(\mathrm{dt}, \mathrm{J}=16.7,2.8 \mathrm{~Hz}, 1 \mathrm{H}), 3.43-3.50$ (m, 2H), 3.65-3.75 (m, 2H), 3.86 (d, J = 10.8 Hz, 1H), 4.16-4.22 (m, 2H), 4.42 (brd, J = 16.7 Hz, 1H), 4.61 (brs, 1H), 5.17 (brs, 1H), 5.23 (d, J = 13.0 Hz, 1H), 5.63 (q, J = 2.7 $\mathrm{Hz}, 1 \mathrm{H}), 5.69$ (dt, J = 3.5, $12.7 \mathrm{~Hz}, 1 \mathrm{H}), 5.85$ (brs, 1H), 7.54-7.80 (m, 5H); ${ }^{13} \mathrm{C}$ NMR $\left(100 \mathrm{MHz}, \mathrm{CDCl}_{3}\right) \delta 28.4,37.0,44.6,46.9,48.7,51.8,60.6,71.1,78.2,81.5,81.6,113.2,127.4,129.2,130.3$, 132.9, 133.0, 136.5, 142.2, 157.1 (br); IR (thin film) v 3438, 2980, 1676, 1407, 1351, 1157, $689 \mathrm{~cm}^{-1}$; LRMS (FAB) $m / z 493$ (M+H), 393; HRMS (FAB) m/z Calcd for $\mathrm{C}_{24} \mathrm{H}_{33} \mathrm{~N}_{2} \mathrm{O}_{7} \mathrm{~S}(\mathrm{M}+\mathrm{H})$ 493.2008, Found 493.1989; Anal. Calcd for $\mathrm{C}_{24} \mathrm{H}_{32} \mathrm{~N}_{2} \mathrm{O}_{7} \mathrm{~S}$ C: 58.52, H: 6.55, N: 5.69, Found C: 58.87, H: 6.80, N: 5.25.

\section{Synthesis of compound $\mathbf{1 7}$ by furan-iminium cation cyclization}

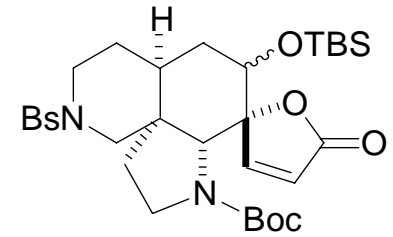

17

To a solution of 13 (930 mg, $1.5 \mathrm{mmol})$ in $\mathrm{CH}_{2} \mathrm{Cl}_{2}(24 \mathrm{~mL})$ was added $\mathrm{AcOH}$ (6 $\mathrm{mL})$ and $\mathrm{H}_{2} \mathrm{O}(0.14 \mathrm{~mL}, 7.5 \mathrm{mmol})$ at room temperature. After stirring for $72 \mathrm{~h}$ at the same temperature, the reaction was quenched by addition of $\mathrm{NaHCO}_{3}$ aq. The mixture was extracted with AcOEt and the combined organic layers were washed with

$\mathrm{NaHCO}_{3}$ aq, dried over $\mathrm{Na}_{2} \mathrm{SO}_{4}$ and concentrated in vacuo. The crude lactol was dissolved in DMSO (30 mL) and added IBX (2.1 g, $7.5 \mathrm{mmol})$. After stirring for $6 \mathrm{~h}$ at $50{ }^{\circ} \mathrm{C}$, the reaction was quenched by addition of $\mathrm{NaHCO}_{3}$ aq. The mixture was extracted with AcOEt and the combined organic layers were washed with $\mathrm{NaHCO}_{3}$ aq and water, dried over $\mathrm{Na}_{2} \mathrm{SO}_{4}$ and concentrated in vacuo. The residue was purified by flash column chromatography on silica gel (hexane:AcOEt $=5: 2$ ) to afford the cyclized lactone $\mathbf{1 7}$ as a colorless foam (850 mg, 91\% in 2 steps): ${ }^{1} \mathrm{H}$ NMR (400 MHz, DMSO- $d_{6}, 120{ }^{\circ} \mathrm{C}$ ) $\delta-0.03$ (s, 3H), -0.01 (s, 3H), 0.76 (s, $4.5 \mathrm{H}), 0.85$ (s, 4.5H), 1.36 (s, 4.5H), 1.45 (s, 4.5H), 1.23-2.32 (m, 8.5H), 2.56 (brd, J = $12.0 \mathrm{~Hz}, 0.5 \mathrm{H})$, 3.02-3.09 (m, 2H), 3.25-3.39 (m, 1.5H), 3.63 (brd, J = 9.8 Hz, 0.5H), 3.80-3.82 (m, 0.5H), 4.08 (s, 0.5H), 4.25-4.29 (m, 1H), 5.95 (br, 0.5H), 6.11 (d, J = 5.6 Hz, 0.5H), 7.48 (d, J = 5.6 Hz, 0.5H), 7.55-7.72 (m, 5.5H); ${ }^{13} \mathrm{C}$ NMR (100 MHz, DMSO- $\left.d_{6}, 120^{\circ} \mathrm{C}\right) \delta-6.0,-5.5,-5.2,-5.1,16.9$ (2C), 24.9, 25.0, 27.4, 27.5, 27.6, 28.1, 30.8, 31.1, 31.7, 32.27, 32.29, 32.33, 43.22, 43.24, 43.7, 43.9, 44.1, 45.8, 51.1, 52.6, 57.9, 58.2, 65.0, 72.9, 78.4, 78.7, 90.4, 92.3, 119.0, 119.4, 126.4, 126.6, 128.6 (2C), 132.12, 132.13, 136.2, 136.8, 152.9, 153.1, 157.8, 159.1, 170.5, 171.5; IR (thin film) v 2932, 1758, 1690, 1392, 1169, 835, $777 \mathrm{~cm}^{-1}$; LRMS (FAB) $\mathrm{m} / \mathrm{z} 657$ (M+K), 563, 519, 


\section{Synthesis of compound $\mathbf{1 8}$ by furan-iminium cation cyclization}

To a solution of 14 (100 mg, $0.17 \mathrm{mmol})$ in acetone- $\mathrm{H}_{2} \mathrm{O}(3: 1,3.4 \mathrm{~mL})$ was added $p-\mathrm{TsOH} \cdot \mathrm{H}_{2} \mathrm{O}(10 \mathrm{mg}, 0.051$

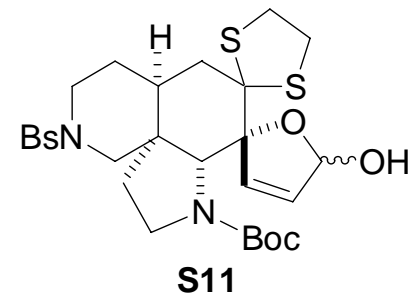
mmol) at room temperature. After stirring for $96 \mathrm{~h}$ at the same temperature, the reaction was quenched by addition of $\mathrm{NaHCO}_{3}$ aq. The mixture was extracted with AcOEt and the combined organic layers were washed with $\mathrm{NaHCO}_{3}$ aq, dried over $\mathrm{Na}_{2} \mathrm{SO}_{4}$ and concentrated in vacuo. The residue was purified by flash column chromatography on silica gel to afford the cyclized lactol S11 as a colorless foam (60 mg, 60\%) and the starting material 14 (39 mg, 39\%).

To a solution of S11 (60 mg, $0.10 \mathrm{mmol}$ ) in DMSO (2 mL) was added IBX (87 mg, $0.31 \mathrm{mmol})$. After stirring for $6 \mathrm{~h}$ at $50{ }^{\circ} \mathrm{C}$, the reaction was quenched by addition of $\mathrm{NaHCO}_{3}$ aq. The mixture was extracted with AcOEt and the combined organic layers were washed with $\mathrm{NaHCO}_{3}$ aq and water, dried over $\mathrm{Na}_{2} \mathrm{SO}_{4}$ and concentrated in vacuo. The residue was purified by flash column chromatography on silica gel (hexane:AcOEt $=1: 1$ ) to afford the cyclized lactone 18 as a colorless foam (60 mg, quant): ${ }^{1} \mathrm{H}$ NMR (400 MHz, DMSO- $\left.d_{6}, 120{ }^{\circ} \mathrm{C}\right) \delta 1.40(\mathrm{~s}, 9 \mathrm{H}$ ),

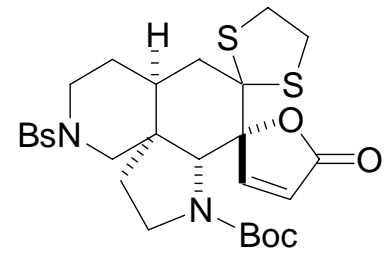

18 1.76-2.27 (m, 6H), 2.42-2.45 (m, 1H), 2.76-3.14 (m, 8H), 3.32-3.47 (m, 2H), 4.05 (s, 1H), 6.19 (brd, $\mathrm{J}=5.7 \mathrm{~Hz}, 1 \mathrm{H}), 7.59-7.74(\mathrm{~m}, 6 \mathrm{H})$; ${ }^{13} \mathrm{C} \mathrm{NMR}\left(100 \mathrm{MHz}, \mathrm{CDCl}_{3}\right.$, major rotational isomer) $\delta 27.5,28.2,33.3,34.0,39.1,40.7,42.6,45.3,45.4,45.6$, 49.6, 63.5, 70.0, 80.5, 95.7, 122.1, 127.5, 129.3, 133.0, 136.2, 155.2, 157.3, 172.1; IR (thin film) $v$ 2926, 1745, 1693, 1384, 1336, 1159, $757 \mathrm{~cm}^{-1}$; LRMS (FAB) $\mathrm{m} / \mathrm{z} 617$ (M+K), 479, 429; HRMS (FAB) $\mathrm{m} / \mathrm{z}$ Calcd for $\mathrm{C}_{27} \mathrm{H}_{34} \mathrm{~N}_{2} \mathrm{O}_{6} \mathrm{~S}_{3} \mathrm{~K}(\mathrm{M}+\mathrm{K})$ 617.1216,

Found 617.1165.

\section{Synthesis of compound $\mathbf{1 9}$}

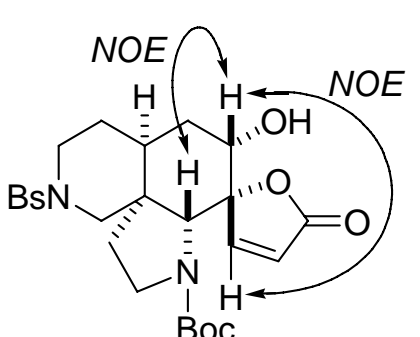

$\mathrm{S} 12(\alpha-\mathrm{OH})$

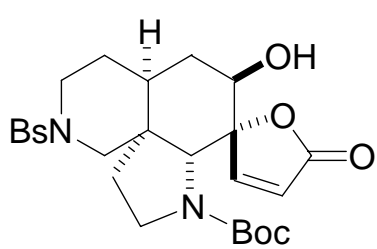

S12 ( $\beta-\mathrm{OH})$

To a solution of $17(400 \mathrm{mg}, 0.65 \mathrm{mmol})$ in THF $(7 \mathrm{~mL})$ was added a $1.0 \mathrm{M}$ TBAF solution in THF $(1.9 \mathrm{~mL}, 1.9 \mathrm{mmol})$ at $0{ }^{\circ} \mathrm{C}$. After stirring for $2 \mathrm{~h}$ at the same temperature, the reaction was quenched by addition of water. The mixture was extracted with AcOEt and the combined organic layers were washed with brine, dried over $\mathrm{Na}_{2} \mathrm{SO}_{4}$ and concentrated in vacuo. The residue was purified by flash column chromatography on silica gel (AcOEt) to afford the desilylated product $\mathbf{S 1 2}$ as a colorless foam (330 mg, quant, $\alpha-\mathrm{OH}: \beta-\mathrm{OH}=1: 1$, diastereomers could be separable by flash chromatography): $\boldsymbol{\alpha}$-OH isomer; ${ }^{1} \mathrm{H}$ NMR (400 MHz, DMSO- $d_{6}$, $\left.120^{\circ} \mathrm{C}\right) \delta 1.33-1.42(\mathrm{~m}, 1 \mathrm{H}), 1.40(\mathrm{~s}, 9 \mathrm{H}), 1.51-1.53(\mathrm{~m}, 1 \mathrm{H}), 1.65-1.67(\mathrm{~m}, 1 \mathrm{H})$, 1.80-2.05 (m, 4H), 2.21-2.36 (m, 2H), 3.09 (brt, J = 10.3 Hz, 1H), 3.28-3.35 (m, 2H), 3.63 (brd, $\mathrm{J}=11.0 \mathrm{~Hz}, 1 \mathrm{H}), 4.02$ (dd, $\mathrm{J}=3.6,11.7 \mathrm{~Hz}, 1 \mathrm{H}), 4.22$ (s, 1H), 4.36 (brm, 1H), 5.96 (br, 1H), 7.46 (d, J = 5.7 Hz, 1H), 7.58-7.73 (m, 5H); ${ }^{13} \mathrm{C}$ NMR (100 MHz, DMSO- $\left.d_{6}, 120{ }^{\circ} \mathrm{C}\right) \delta 27.5,27.8,30.6,31.1$ (br), 32.4, 43.2, 43.8, 45.7, 52.6, 58.4, 63.3, 78.4, 92.6, 119.3 (br), 126.6, 128.6, 132.2, 136.3, 153.0, 158.1, 171.7; IR (thin film) v 3446, 2933, 1750, 1685, 1394, 1337, 1165, 1132, $739 \mathrm{~cm}^{-1}$; LRMS (FAB) m/z $543(\mathrm{M}+\mathrm{K})$, 449, 404, 387; HRMS (FAB) $\mathrm{m} / \mathrm{z}$ Calcd for $\mathrm{C}_{25} \mathrm{H}_{32} \mathrm{~N}_{2} \mathrm{O}_{7} \mathrm{SK}(\mathrm{M}+\mathrm{K}$ ) 
543.1567, Found 543.1559: $\beta$-OH isomer; ${ }^{1} \mathrm{H}$ NMR (400 MHz, DMSO- $d_{6}, 120{ }^{\circ} \mathrm{C}$ ) $\delta 1.39$ (s, 9H), 1.55 (ddd, $\mathrm{J}=$ 4.7, 7.1, $14.1 \mathrm{~Hz}, 1 \mathrm{H}), 1.69-1.74$ (m, 2H), 1.88-2.15 (m, 4H), 2.56 (brd, J = 11.9 Hz, 1H), 2.82 (br, 1H), 3.03-3.13 (m, 3H), 3.34 (dt, J = 10.8, 8.6 Hz, 1H), 3.65 (q, J = 4.9 Hz, 1H), 4.10 (s, 1H), 5.22 (d, J = 5.3 Hz, 1H), 6.05 (d, J $=5.3 \mathrm{~Hz}, 1 \mathrm{H}), 7.58-7.74(\mathrm{~m}, 6 \mathrm{H}) ;{ }^{13} \mathrm{C}$ NMR $\left(100 \mathrm{MHz}\right.$, DMSO- $\left.d_{6}, 120{ }^{\circ} \mathrm{C}\right) \delta 27.5,28.1,30.6,32.06,32.11,43.7$, 44.0, 44.3, 51.0, 58.1, 71.5, 78.6, 91.0, 118.5, 126.5, 128.6, 132.2, 136.8, 153.3, 159.9, 170.9; IR (thin film) $v$ 3396, 2926, 1753, 1689, 1393, 1337, 1162, $985 \mathrm{~cm}^{-1}$; LRMS (FAB) m/z 543 (M+K), 449, 431, 404, 387; HRMS (FAB) $\mathrm{m} / z$ Calcd for $\mathrm{C}_{25} \mathrm{H}_{32} \mathrm{~N}_{2} \mathrm{O}_{7} \mathrm{SK}(\mathrm{M}+\mathrm{K})$ 543.1567, Found 543.1606.

\section{Synthesis of compound $\mathbf{2 0}$}

To a solution of $\mathbf{S 1 2}$ (300 mg, $\alpha-\mathrm{OH}: \beta-\mathrm{OH}=1: 1,0.59 \mathrm{mmol})$ in $\mathrm{MeOH}(6 \mathrm{~mL})$ was added $\mathrm{PtO}_{2}(60 \mathrm{mg})$ and the reaction flask was purged with $\mathrm{H}_{2}$ gas using a balloon. After stirring for $4 \mathrm{~h}$ at room temperature, the mixture was filtered through a pad of Celite ${ }^{\circledR}$ and eluted with AcOEt. The combined filtrates were washed with brine, dried over $\mathrm{Na}_{2} \mathrm{SO}_{4}$ and concentrated in vacuo to afford the hydrogenated product 19 as a colorless foam (300 mg, quant, $\alpha-\mathrm{OH}: \beta-\mathrm{OH}=1: 1$, diastereomers could be separable by flash chromatography on silica gel (AcOEt)):

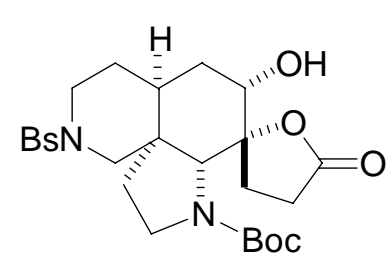

$19 \mathrm{a}$

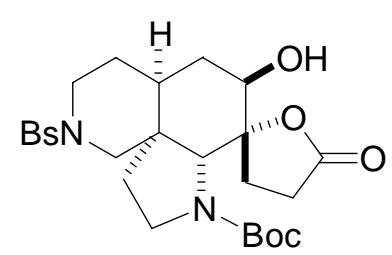

$19 \mathrm{~b}$ $\alpha$-OH isomer (19a); ${ }^{1} \mathrm{H}$ NMR (400 MHz, DMSO- $\left.d_{6}, 120{ }^{\circ} \mathrm{C}\right) \delta 1.27-1.32(\mathrm{~m}, 1 \mathrm{H})$, 1.40-1.45 (m, 1H), 1.47 (s, 9H), 1.60-1.76 (m, 3H), 1.88-1.97 (m, 2H), 2.15-2.37 (m, 4H), 2.42-2.57 (m, 2H), 3.11 (brt, J = $10.0 \mathrm{~Hz}, 1 \mathrm{H}$ ), 3.25 (dd, J = 1.8, $12.2 \mathrm{~Hz}, 1 \mathrm{H}$ ), 3.36-3.43 (m, 1H), 3.59-3.67 (m, 2H), 4.05 (s, 1H), 4.65 (brd, J = $5.7 \mathrm{~Hz}, 1 \mathrm{H}$ ), 7.58-7.72 (m, 5H); ${ }^{13} \mathrm{C}$ NMR (100 MHz, DMSO- $\left.d_{6}, 120{ }^{\circ} \mathrm{C}\right) \delta 26.7,27.5,27.7,27.8$, 30.2, 31.4, 32.4, 43.6, 44.2, 45.8, 52.6, 62.0, 66.8, 78.8, 89.2, 126.6, 128.5, 132.1, 136.3, 154.0 (br), 175.6; IR (thin film) v 3429, 2945, 1769, 1685, 1391, 1339, 1163, 1127, $738 \mathrm{~cm}^{-1}$; LRMS (FAB) m/z 545 (M+K), 451, 407, 389; HRMS (FAB) $\mathrm{m} / \mathrm{z}$ Calcd for $\mathrm{C}_{25} \mathrm{H}_{34} \mathrm{~N}_{2} \mathrm{O}_{7} \mathrm{SK}(\mathrm{M}+\mathrm{K})$ 545.1724, Found 545.1713: $\beta$-OH isomer (19b); ${ }^{1} \mathrm{H}$ NMR (400 MHz, DMSO-d $\left.d_{6}, 120{ }^{\circ} \mathrm{C}\right) \delta 1.43-1.57(\mathrm{~m}, 2 \mathrm{H}), 1.46(\mathrm{~s}, 9 \mathrm{H}), 1.60-1.66$ (m, 1H), 1.76-1.81 (m, 1H), 1.92-2.09 (m, 2H), 2.20-2.52 (m, 6H), 2.60-2.66 (m, 1H), 3.04-3.10 (m, 2H), 3.17-3.22 (m, 1H), 3.44 (dt, J = 11.2, 8.6 Hz, 1H), 3.69-3.71 (m, 1H), 4.04 (s, 1H), 5.00 (brd, J = 4.8 Hz, 1H), 7.58-7.71 (m, $5 \mathrm{H}) ;{ }^{13} \mathrm{C}$ NMR (100 MHz, DMSO- $\left.d_{6}, 150{ }^{\circ} \mathrm{C}\right) \delta 26.7,27.4,27.5,28.2,29.9,31.9,32.5,43.7,44.1,44.5,51.2$, 61.2, 70.7, 78.8, 87.8. 126.3, 128.3, 131.8, 136.9, 154.3, 174.8; IR (thin film) $v$ 3431, 2941, 1753, 1687, 1393, 1337, 1162, $755 \mathrm{~cm}^{-1}$; LRMS (FAB) m/z 545 (M+K), 489, 451, 407, 389; HRMS (FAB) $\mathrm{m} / \mathrm{z}$ Calcd for $\mathrm{C}_{25} \mathrm{H}_{34} \mathrm{~N}_{2} \mathrm{O}_{7} \mathrm{SK}(\mathrm{M}+\mathrm{K})$ 545.1724, Found 545.1713.

To a solution of 19 (300 mg, $\alpha-\mathrm{OH}: \beta-\mathrm{OH}=1: 1,0.59 \mathrm{mmol})$ in $\mathrm{CH}_{2} \mathrm{Cl}_{2}(6 \mathrm{~mL})$ was added Dess-Martin periodinane $(750 \mathrm{mg}, 1.8 \mathrm{mmol}$ ) at room temperature. After stirring for $6 \mathrm{~h}$ at the same temperature, the mixture was quenched with $\mathrm{NaHCO}_{3}$ aq and extracted with AcOEt. The combined organic layers were washed with

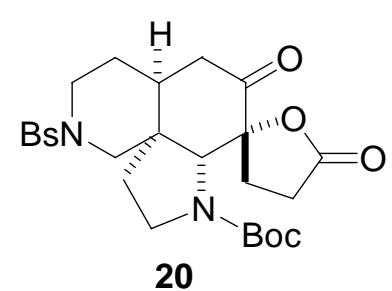

20 $\mathrm{NaHCO}_{3}$ aq and brine, dried over $\mathrm{Na}_{2} \mathrm{SO}_{4}$ and concentrated in vacuo. The residue was purified by flash column chromatography on silica gel (hexane:AcOEt $=1: 1$ ) to afford the ketone 20 as a colorless solid (285 mg, 95\%): mp $202{ }^{\circ} \mathrm{C}$ (hexane-AcOEt); ${ }^{1} \mathrm{H}$ NMR (400 MHz, DMSO- $\left.d_{6}, 120{ }^{\circ} \mathrm{C}\right) \delta 1.22-1.27$ (m, $\left.1 \mathrm{H}\right), 1.47$ (s, 9H), 1.64-1.75 (m, 2H), 2.15-2.59 (m, 8H), 2.71-2.76 (m, 1H), 3.06 (dd, J = 5.0, $14.2 \mathrm{~Hz}, 1 \mathrm{H}), 3.23-3.28$ 
(m, 2H), 3.40-3.44 (m, 1H), 3.56 (dt, J = 11.0, $8.8 \mathrm{~Hz}, 1 \mathrm{H}), 4.25$ (s, 1H), 7.58-7.73 (m, 5H); ${ }^{13} \mathrm{C}$ NMR (100 MHz, DMSO- $\left.d_{6}, 120{ }^{\circ} \mathrm{C}\right) \delta 23.7,26.7,27.4,27.9,30.9,33.6,38.3,44.3,44.5,44.6,51.3,64.4,79.4,87.6,126.5,128.6$, 132.2, 136.4, 153.9, 174.0, 202.5; IR (thin film) v 2898, 1776, 1687, 1388, 1332, 1157, 1122, $750 \mathrm{~cm}^{-1}$; LRMS (FAB) $\mathrm{m} / \mathrm{z} 505$ (M+H), 449, 405, 307, 154; Anal. Calcd for $\mathrm{C}_{25} \mathrm{H}_{32} \mathrm{~N}_{2} \mathrm{O}_{7} \mathrm{~S}$ C: 59.51, H: 6.39, N: 5.55, Found C: 59.38, H: 6.21, N: 5.43 .

\section{Synthesis of compound $\mathbf{1 9 b}$ by reduction of $\mathbf{2 0}$}

To a solution of 20 (200 mg, $0.40 \mathrm{mmol})$ in $\mathrm{MeOH}(4 \mathrm{~mL})$ was added $\mathrm{PtO}_{2}(40 \mathrm{mg})$ and the mixture was stirred under $\mathrm{H}_{2}$ atmosphere for $12 \mathrm{~h}$ at room temperature. The mixture was filtered through a pad of Celite ${ }^{\circledR}$ and eluted with AcOEt. The combined filtrates were washed with brine, dried over $\mathrm{Na}_{2} \mathrm{SO}_{4}$ and concentrated in vacuo to afford 19b (178 mg, 89\%).

\section{Synthesis of compound 22}

To a solution of 19b (600 mg, $1.2 \mathrm{mmol})$ in degassed $\mathrm{CH}_{2} \mathrm{Cl}_{2}(20 \mathrm{~mL})$ was added Martin sulfurane (2.4 g, 3.6 $\mathrm{mmol}$ ) at room temperature. After stirring for $12 \mathrm{~h}$ at the same temperature, the mixture was concentrated in vacuo. The residue was purified by flash column chromatography on silica gel (hexane:AcOEt $=1: 1$ ) to afford the olefin 22 as a colorless foam (513 mg, 88\%): ${ }^{1} \mathrm{H}$ NMR (400 MHz, DMSO- $\left.\mathrm{d}_{6}, 120{ }^{\circ} \mathrm{C}\right) \delta 1.14-1.24(\mathrm{~m}, 1 \mathrm{H}), 1.40-1.53(\mathrm{~m}$,

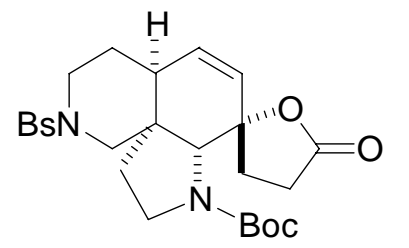

22 $10 \mathrm{H}), 1.85-1.93$ (m, 2H), 2.10-2.20 (m, 2H), 2.30 (d, J = 12.4 Hz, 1H), 2.50-2.62 (m, $4 \mathrm{H}), 3.12(\mathrm{dt}, \mathrm{J}=2.1,10.3 \mathrm{~Hz}, 1 \mathrm{H}), 3.33-3.40(\mathrm{~m}, 2 \mathrm{H}), 3.51-3.54(\mathrm{~m}, 1 \mathrm{H}), 4.16(\mathrm{~s}$, $1 \mathrm{H}), 5.67(\mathrm{~d}, \mathrm{~J}=10.0 \mathrm{~Hz}, 1 \mathrm{H}), 5.88(\mathrm{dd}, \mathrm{J}=5.5,10.0 \mathrm{~Hz}, 1 \mathrm{H}), 7.58-7.75(\mathrm{~m}, 5 \mathrm{H}) ;{ }^{13} \mathrm{C}$ NMR (100 MHz, DMSO- $\left.d_{6}, 120^{\circ} \mathrm{C}\right) \delta 27.0,27.5,30.0,31.3,34.5,35.5,43.2,43.4$, 44.6, 51.3, 63.0, 78.6, 81.0, 126.5, 128.2, 128.6, 131.3, 132.1, 136.7, 153.7, 175.1; IR (thin film) $v$ 2971, 1769, 1685, 1394, 1336, 1162, 1096, 919, $750 \mathrm{~cm}^{-1}$; LRMS (FAB) $\mathrm{m} / \mathrm{z} 527$ (M+K), 511, 471, 433, 389, 371; HRMS (FAB) $m / z$ Calcd for $\mathrm{C}_{25} \mathrm{H}_{32} \mathrm{~N}_{2} \mathrm{O}_{6} \mathrm{SK}(\mathrm{M}+\mathrm{K})$ 527.1618, Found 527.1590.

\section{Synthesis of compound $\mathbf{2 3}$}

To a solution of 22 (150 mg, $0.31 \mathrm{mmol})$ in acetone $(3 \mathrm{~mL})$ was added a dimethyldioxirane solution in acetone (prepared according to a reported procedure ${ }^{2}$, about $0.10 \mathrm{M}, 30 \mathrm{~mL}$, about $3.0 \mathrm{mmol}$ ) at room temperature. After stirring for $6 \mathrm{~h}$ at the same temperature, the reaction was quenched with sodium thiosulfate aqueous solution. The mixture was concentrated in vacuo and extracted with AcOEt. The combined organic layers were washed with

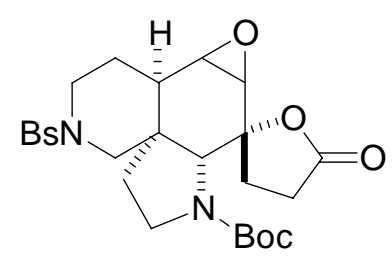

23 brine, dried over $\mathrm{Na}_{2} \mathrm{SO}_{4}$ and concentrated in vacuo. The residue was purified by preparative TLC (silica gel, $\mathrm{CH}_{2} \mathrm{Cl}_{2}: \mathrm{AcOEt}=15: 1$ ) to afford the epoxide 23 as a colorless foam (88 mg, 58\%): ${ }^{1} \mathrm{H}$ NMR (400 MHz, $\left.\mathrm{C}_{6} \mathrm{D}_{6}, 75^{\circ} \mathrm{C}\right) \delta 1.21-1.29(\mathrm{~m}, 1 \mathrm{H})$, 1.35-1.47 (m, 1H), 1.39 (s, 9H), 1.61-1.77 (m, 3H), 1.94-2.00 (m, 1H), 2.01 (ddd, J = 5.2, 10.7, $17.9 \mathrm{~Hz}, 1 \mathrm{H}$ ), 2.28 (ddd, J = 8.0, 10.4, $17.9 \mathrm{~Hz}, 1 \mathrm{H}$ ), 2.46 (dd, $\mathrm{J}=1.1,4.0$ Hz, 1H), 2.58 (d, J = 4.0 Hz, 1H), 2.69 (d, J = 11.9 Hz, 1H), 2.69-2.74 (m, 1H), 2.89 (ddd, J = 5.2, 10.4, $13.1 \mathrm{~Hz}$, 1H), 3.13 (d, $\mathrm{J}=11.9 \mathrm{~Hz}, 1 \mathrm{H}$ ), 3.20 (ddd, $\mathrm{J}=$ 4.8, 9.2, $11.4 \mathrm{~Hz}, 1 \mathrm{H}$ ), 3.27-3.33 (m, 1H), 3.60 (ddd, J = 7.4, 8.4, 11.4 Hz, 1H), 3.91 (s, 1H), 6.96-7.02 (m, 3H), 7.63-7.65 (m, 2H); ${ }^{13} \mathrm{C}$ NMR (100 MHz, $\left.\mathrm{C}_{6} \mathrm{D}_{6}, 75{ }^{\circ} \mathrm{C}\right) \delta 26.7,27.7$,

2 Adam, W.; Bialas, J.; Hadjiarapoglou, L. Chem. Ber. 1991, 124, 2377. 
28.3, 31.3, 36.0, 36.3, 43.2, 45.1, 45.2, 51.1, 55.6, 56.2, 64.8, 80.3, 85.5, 127.5, 129.0, 132.2, 139.2, 156.5, 174.7; IR (thin film) $v$ 2944, 1779, 1685, 1332, 1162, 912, $727 \mathrm{~cm}^{-1}$; LRMS (FAB) m/z 543 (M+K), 503, 449, 405; HRMS (FAB) m/z Calcd for $\mathrm{C}_{25} \mathrm{H}_{32} \mathrm{~N}_{2} \mathrm{O}_{7} \mathrm{SK}(\mathrm{M}+\mathrm{K})$ 543.1567, Found 543.1559.

\section{Synthesis of compound $\mathbf{2 4}$}

$\mathrm{YbCl}_{3} \cdot 6 \mathrm{H}_{2} \mathrm{O}$ (25 mg, $\left.65 \mu \mathrm{mol}\right)$ was weighed to a flask and dried under vacuum at $120^{\circ} \mathrm{C}$ for $2 \mathrm{~h}$. After cooling, THF $(0.3 \mathrm{~mL})$ was added and the suspension was sonicated for $30 \mathrm{~min}$ at room temperature. The suspension was cooled to $-78{ }^{\circ} \mathrm{C}$ and added $n$-butyllithium in hexane $(1.56 \mathrm{M}, 125 \mu \mathrm{L}, 195 \mu \mathrm{mol})$. After stirring for $1 \mathrm{~h}$ at $-78{ }^{\circ} \mathrm{C}$, a solution of TMSCN $(41 \mu \mathrm{L}, 330 \mu \mathrm{mol})$ in THF $(0.3 \mathrm{~mL})$ was added at $-78{ }^{\circ} \mathrm{C}$ and the mixture was warmed to room temperature. After stirring for $30 \mathrm{~min}$, a solution of 23 (33 mg, $65 \mu \mathrm{mol})$ in THF (0.3 mL) was added and the mixture was warmed to $50{ }^{\circ} \mathrm{C}$. After stirring for $12 \mathrm{~h}$ at the same temperature, the mixture was quenched with water and extracted with AcOEt. The combined organic layers were washed with brine, dried over $\mathrm{Na}_{2} \mathrm{SO}_{4}$ and concentrated in vacuo. The crude $\beta$-cyanohydrin silylether was dissolved in THF (0.5 mL) and added a $1.0 \mathrm{M}$ TBAF solution in THF $(0.15 \mathrm{~mL}, 150 \mu \mathrm{mol})$ at $0{ }^{\circ} \mathrm{C}$. After stirring for $2 \mathrm{~h}$ at the same temperature, the mixture was quenched with water and extracted with AcOEt. The combined organic layers were washed with brine, dried over $\mathrm{Na}_{2} \mathrm{SO}_{4}$ and concentrated in vacuo. The residue was purified by flash column chromatography on silica gel

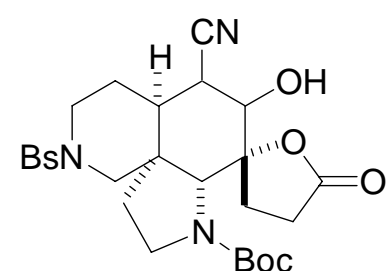

24 (hexane:AcOEt $=1: 1$ ) to afford the $\beta$-cyanohydrin 24 as a colorless foam (23 mg, 67\%): ${ }^{1} \mathrm{H}$ NMR (400 MHz, $\mathrm{C}_{6} \mathrm{D}_{6}, 75{ }^{\circ} \mathrm{C}$ ) $\delta 1.34$ (s, 9H), 1.49-1.77 (m, 5H), 1.91-2.26 (m, 7H), 2.61 (ddd, J = 3.4, 10.0, $13.4 \mathrm{~Hz}, 1 \mathrm{H}), 3.19-3.25$ (m, 2H), 3.31-3.34 (m, 1H), 3.43 (dd, J = 6.1, $6.5 \mathrm{~Hz}, 1 \mathrm{H}), 3.54$ (dt, J = 11.2, 8.6 Hz, 1H), 3.65 (s, 1H), 6.95-7.01 (m, 3H), 7.54-7.56 (m, 2H); ${ }^{13} \mathrm{C}$ NMR (100 MHz, $\left.\mathrm{C}_{6} \mathrm{D}_{6}, 75{ }^{\circ} \mathrm{C}\right) \delta 25.5,27.5,27.6$, 28.3, 34.2, 35.1, 36.5, 41.8, 45.6, 46.0, 49.4, 64.4, 76.3, 80.8, 88.1, 119.6, 127.7, 129.1, 132.5, 138.7, 156.6, 174.6; IR (thin film) v 3426, 2978, 2362, 2242, 1782, 1693, 1367, 1337, $1165 \mathrm{~cm}^{-1}$; LRMS (FAB) m/z 570 (M+K), 476, 432; HRMS (FAB) m/z Calcd for $\mathrm{C}_{26} \mathrm{H}_{33} \mathrm{~N}_{3} \mathrm{O}_{7} \mathrm{SK}(\mathrm{M}+\mathrm{K})$ 570.1676, Found 570.1652.

\section{Synthesis of compound $\mathbf{2 5}$}

To a solution of 24 (21 mg, $40 \mu \mathrm{mol})$ and $\mathrm{Et}_{3} \mathrm{~N}(22 \mu \mathrm{L}, 160 \mu \mathrm{mol})$ in $\mathrm{CH}_{2} \mathrm{Cl}_{2}(0.5 \mathrm{~mL})$ was added methanesulfonyl chloride $(6 \mu \mathrm{l}, 80 \mu \mathrm{mol})$ at $0{ }^{\circ} \mathrm{C}$. The mixture was warmed to room temperature and stirred for 4 h. The mixture was diluted with $\mathrm{CH}_{2} \mathrm{Cl}_{2}$ and washed with $1 \mathrm{~N} \mathrm{HCl}, \mathrm{NaHCO}_{3}$ aq and brine and concentrated in vacuo. The crude mesylate was dissolved in toluene $(0.5 \mathrm{~mL})$ and added DBU (30 $\mu \mathrm{l}, 200 \mu \mathrm{mol})$. The mixture was stirred for $3 \mathrm{~h}$ at $50^{\circ} \mathrm{C}$. After cooling, the mixture was diluted with AcOEt and washed with $1 \mathrm{~N} \mathrm{HCl}$ and brine and concentrated in vacuo. The residue was purified by flash column chromatography on silica gel (hexane:AcOEt = 1:1) to afford the $\alpha, \beta$-unsaturated nitrile 25 as a colorless foam (19 mg, 90\%): ${ }^{1} \mathrm{H}$ NMR (400 MHz, DMSO- $d_{6}$,

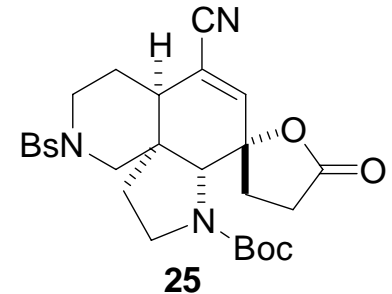

25 $\left.100{ }^{\circ} \mathrm{C}\right) \delta 1.25-1.32(\mathrm{~m}, 1 \mathrm{H}), 1.42(\mathrm{~s}, 9 \mathrm{H}), 1.54-1.58(\mathrm{~m}, 1 \mathrm{H}), 1.76(\mathrm{dt}, \mathrm{J}=12.9,9.8$ Hz, $1 \mathrm{H}), 2.03-2.07$ (m, 1H), 2.28-2.33 (m, 2H), 2.46-2.56 (m, 3H), 2.66 (brm, 2H), 3.13 (brt, J = 9.8 Hz, 1H), 3.39 (dd, J = 9.1, $19.1 \mathrm{~Hz}, 1 \mathrm{H}$ ), 3.44 (dd, J = 1.7, $12.4 \mathrm{~Hz}$, 1H), 3.64-3.67 (m, 1H), 4.23 (s, 1H), 6.78 (s, 1H), 7.61-7.76 (m, 5H); ${ }^{13} \mathrm{C}$ NMR (100 MHz, DMSO- $\left.d_{6}, 100{ }^{\circ} \mathrm{C}\right) \delta 26.7,27.6,29.8,30.4$ (br), 34.2, 37.5, 43.0, 43.5 (br), 44.6, 51.1, 62.3, 79.0, 79.6, 115.0, 116.9, 126.6, 128.8, 132.4, 136.4, 143.8, 153.7 (br), 174,8; IR (thin film) v 2977, 
2222, 1783, 1694, 1402, $1168 \mathrm{~cm}^{-1}$; LRMS (FAB) m/z 552 (M+K), 458, 414; HRMS (FAB) $\mathrm{m} / \mathrm{z}$ Calcd for $\mathrm{C}_{26} \mathrm{H}_{31} \mathrm{~N}_{3} \mathrm{O}_{6} \mathrm{SK}(\mathrm{M}+\mathrm{K})$ 552.1571, Found 552.1570. 


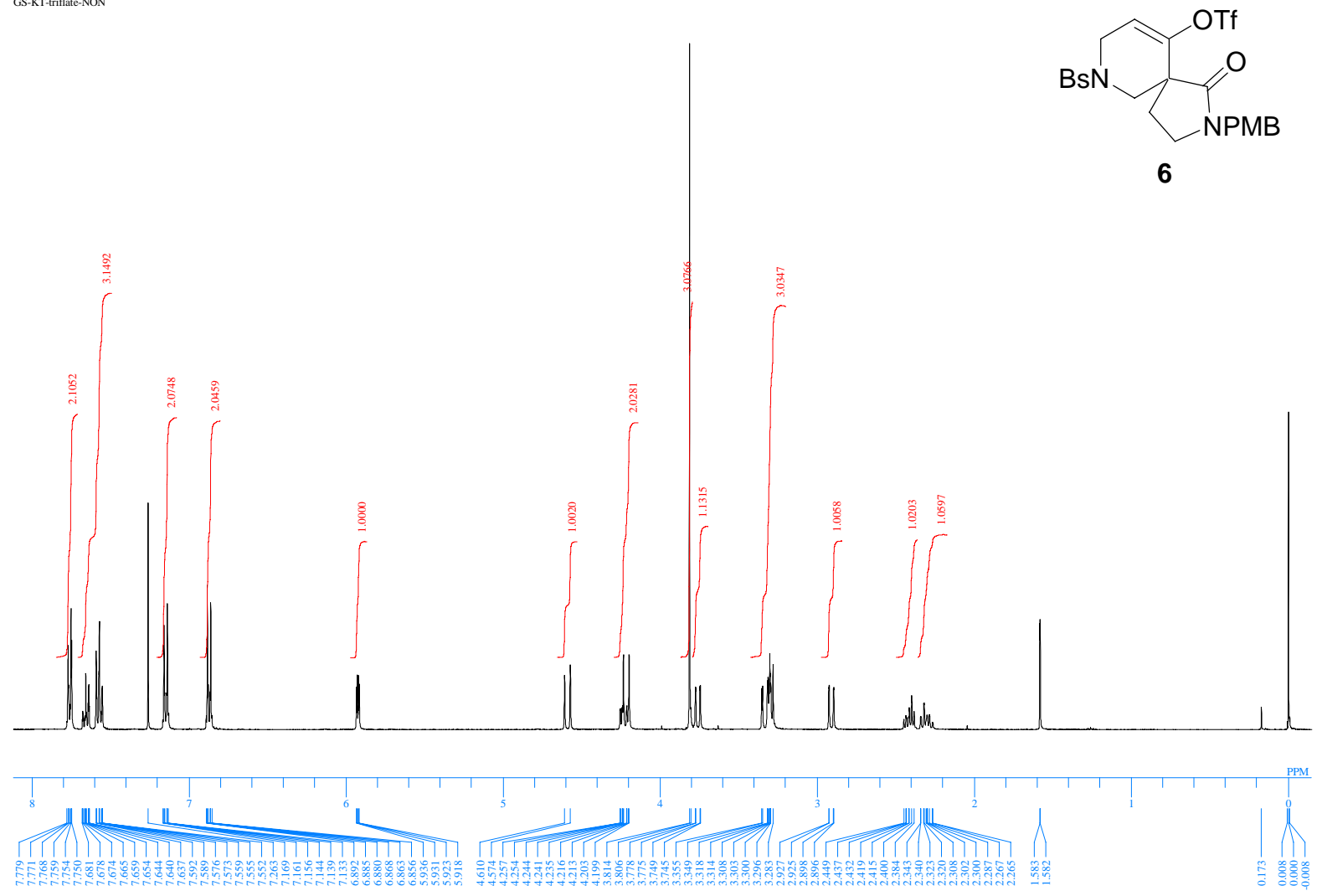

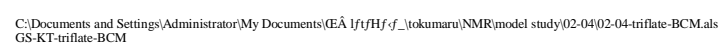

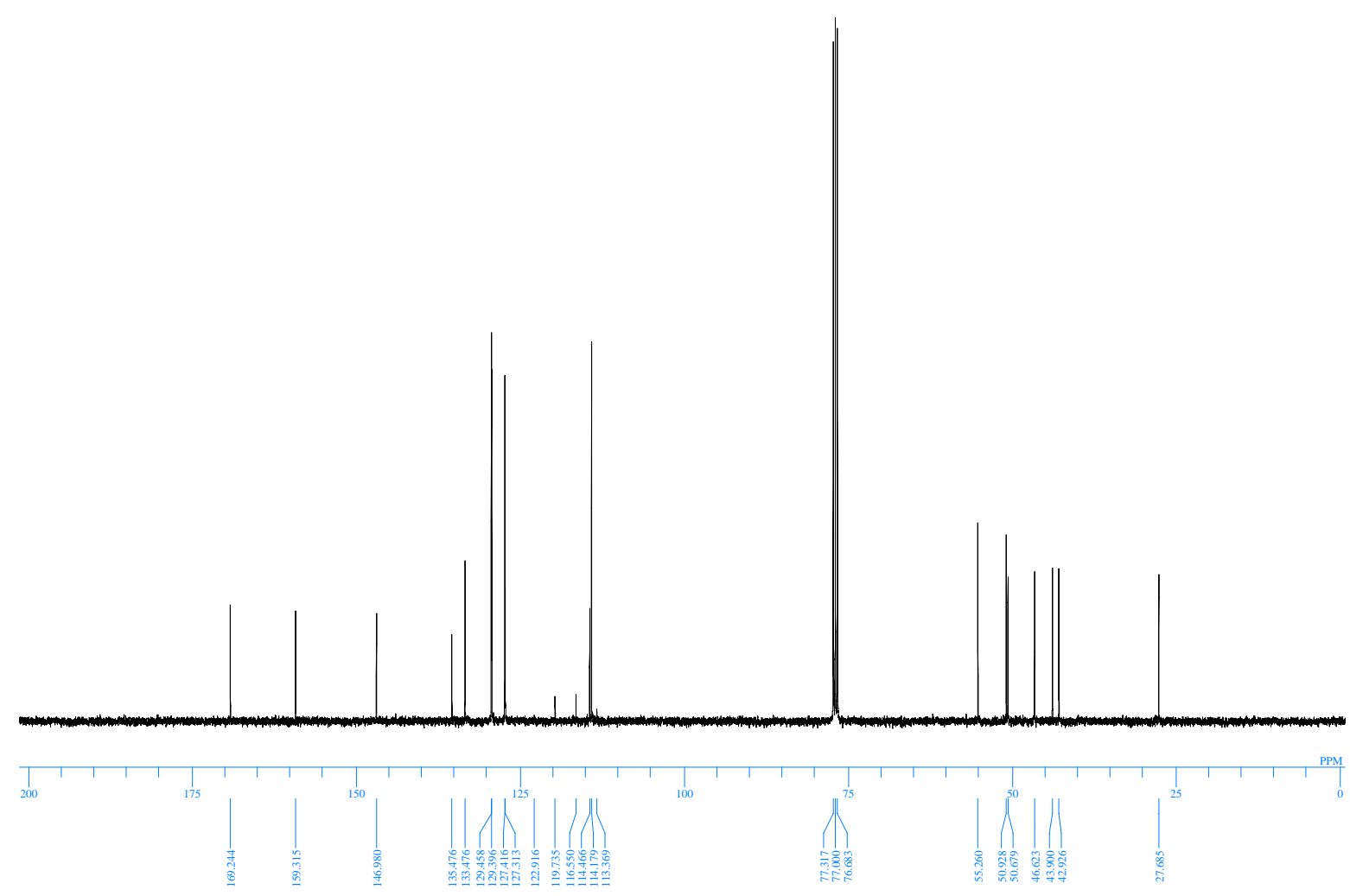




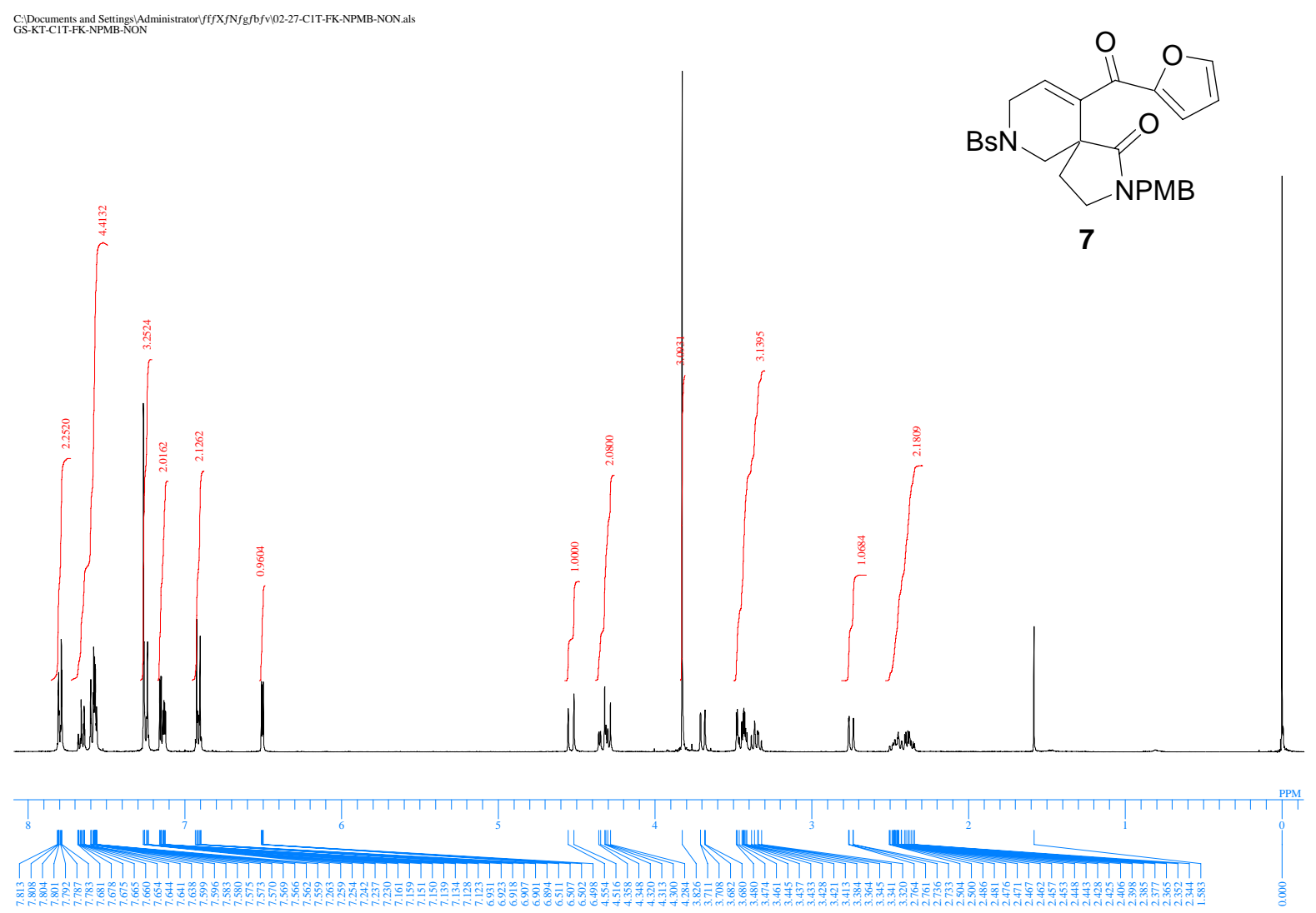

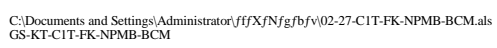

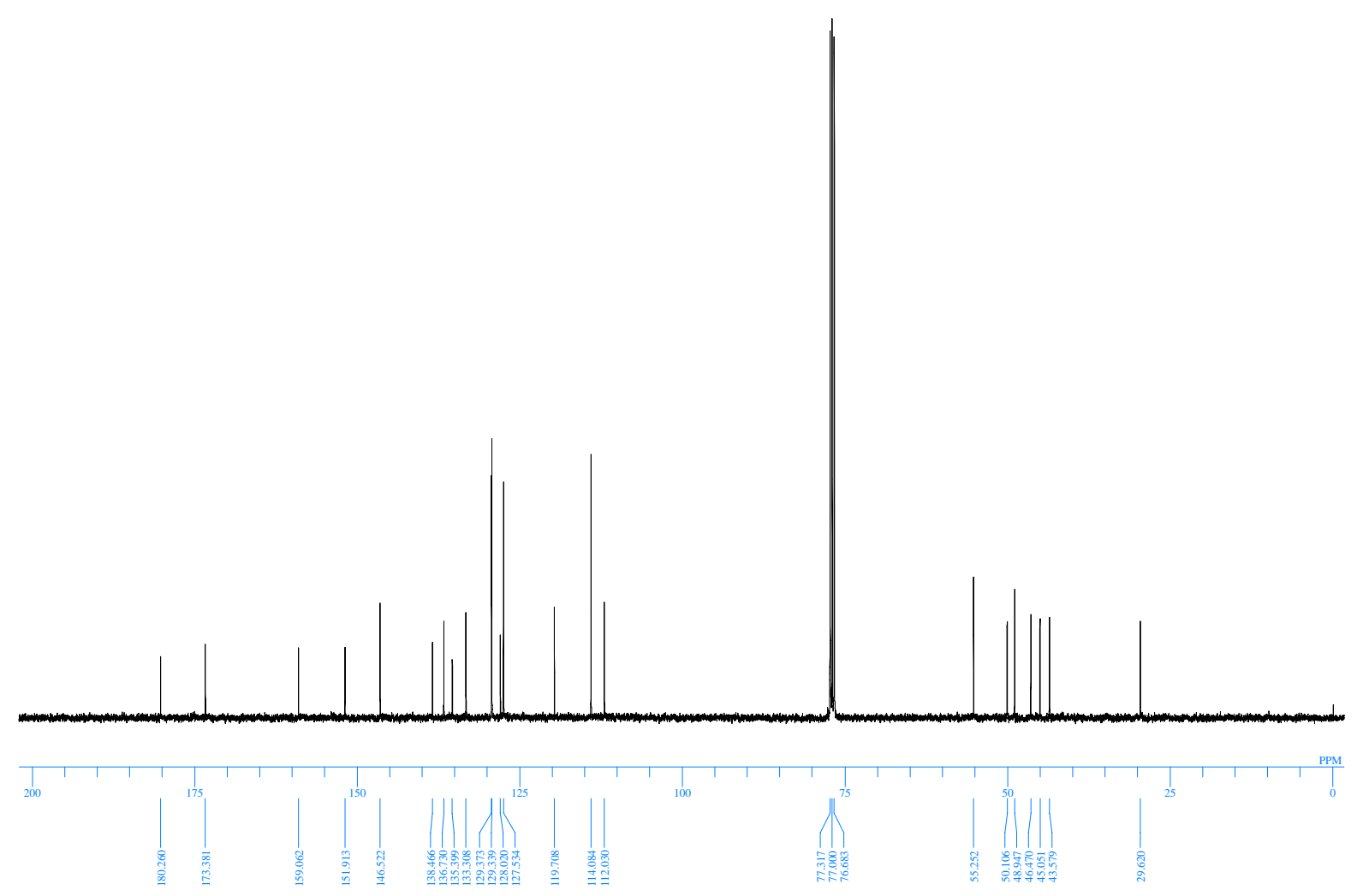




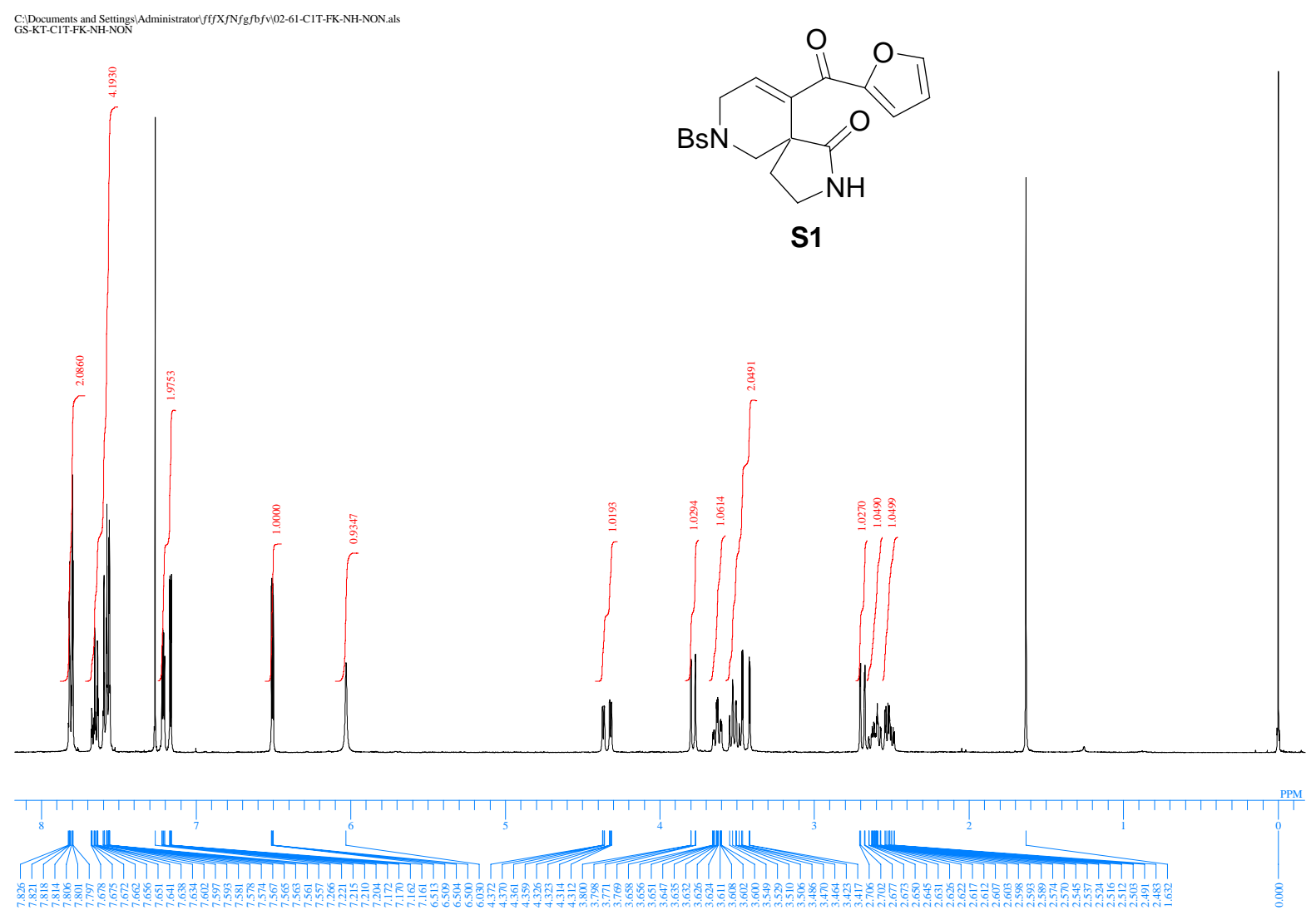

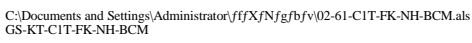

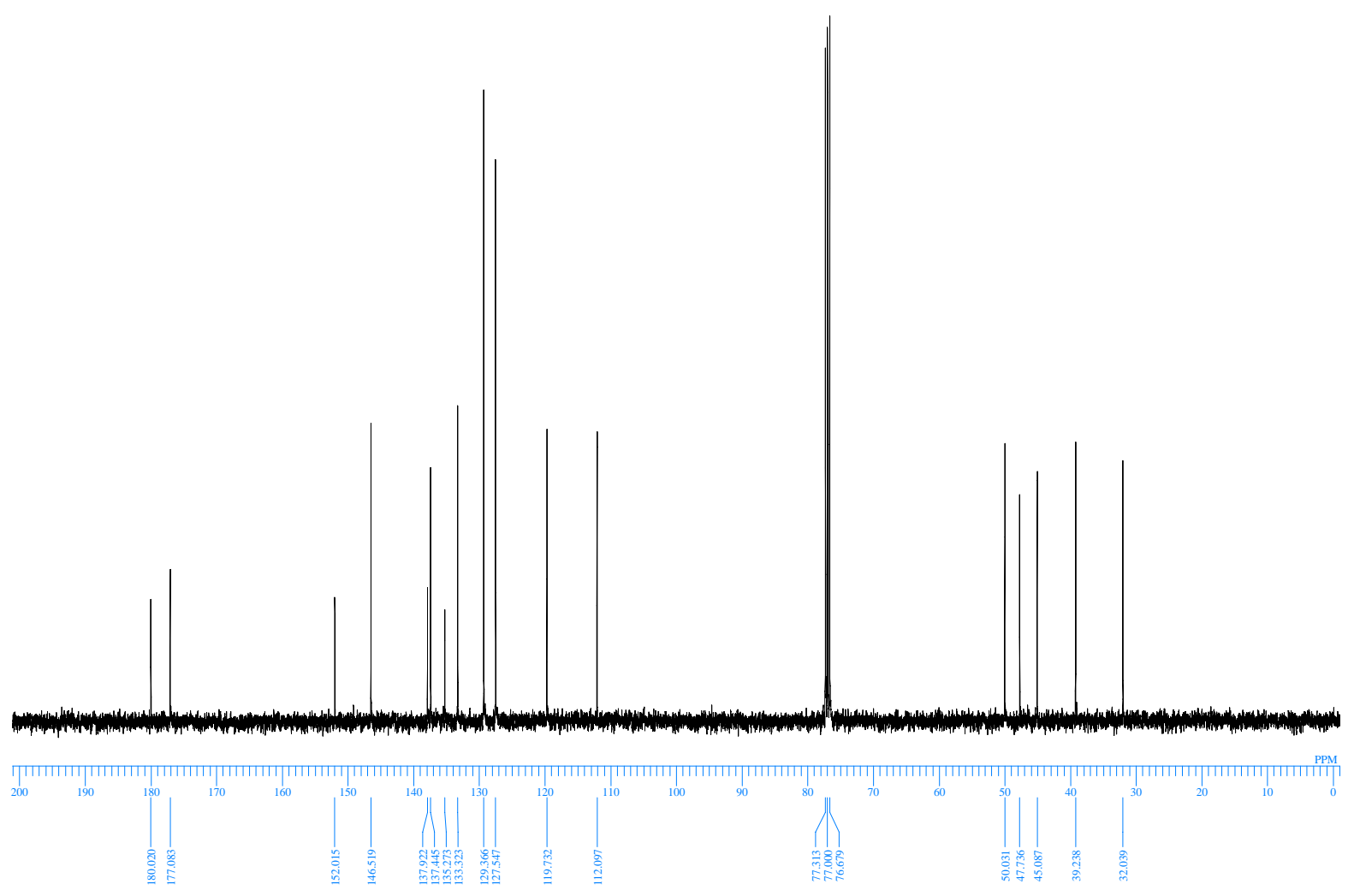




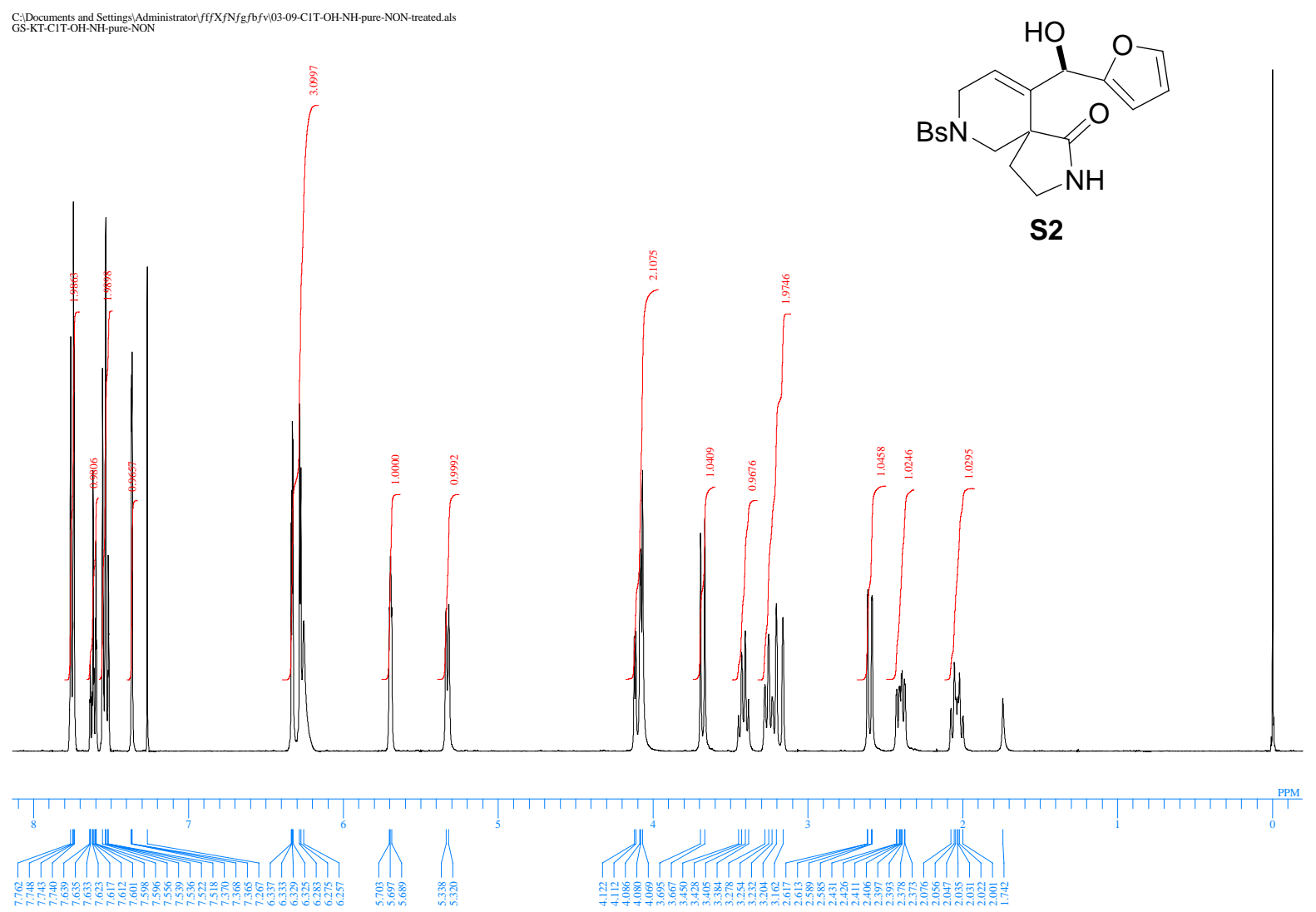

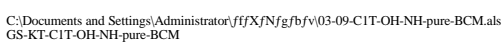

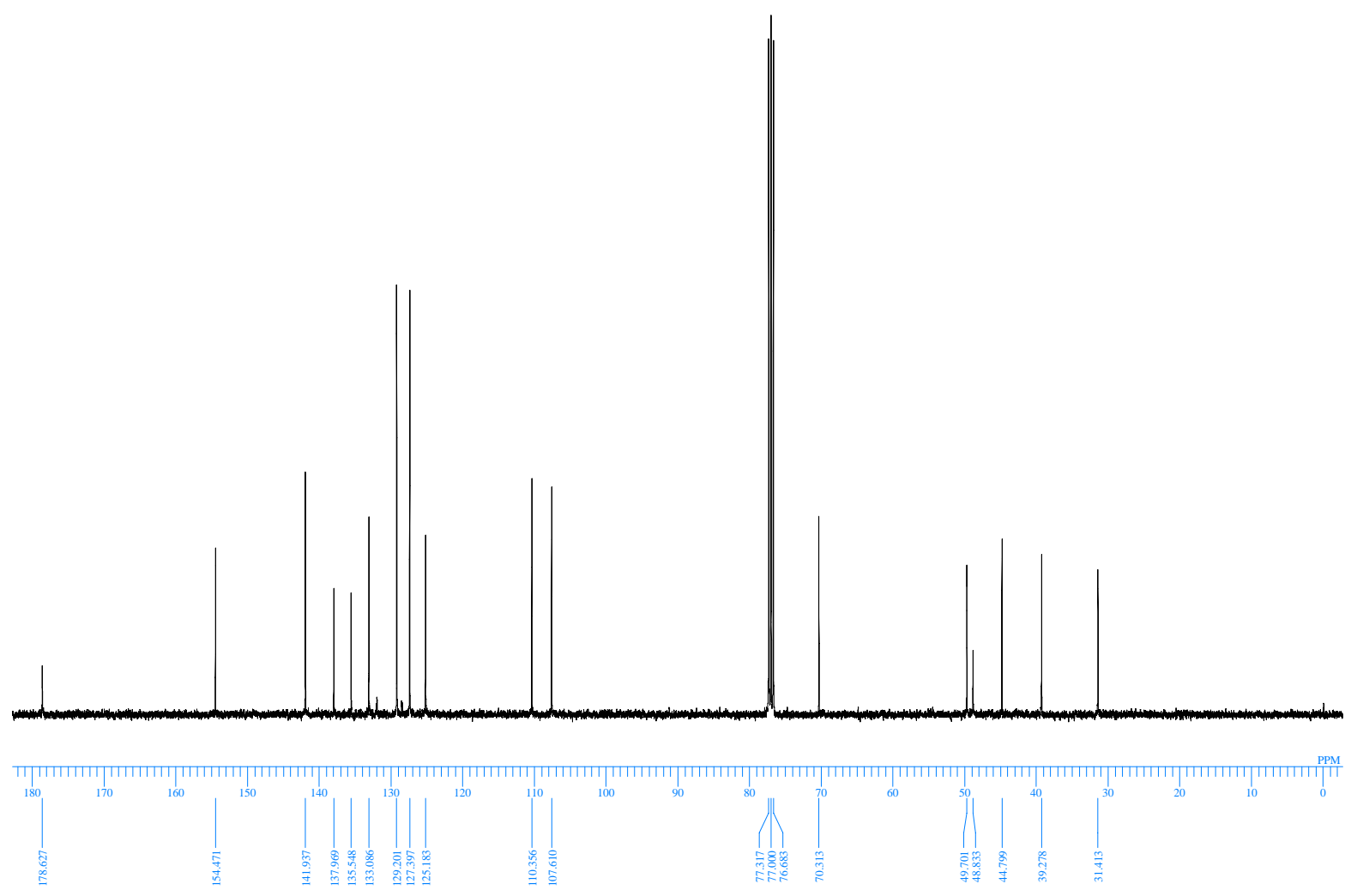



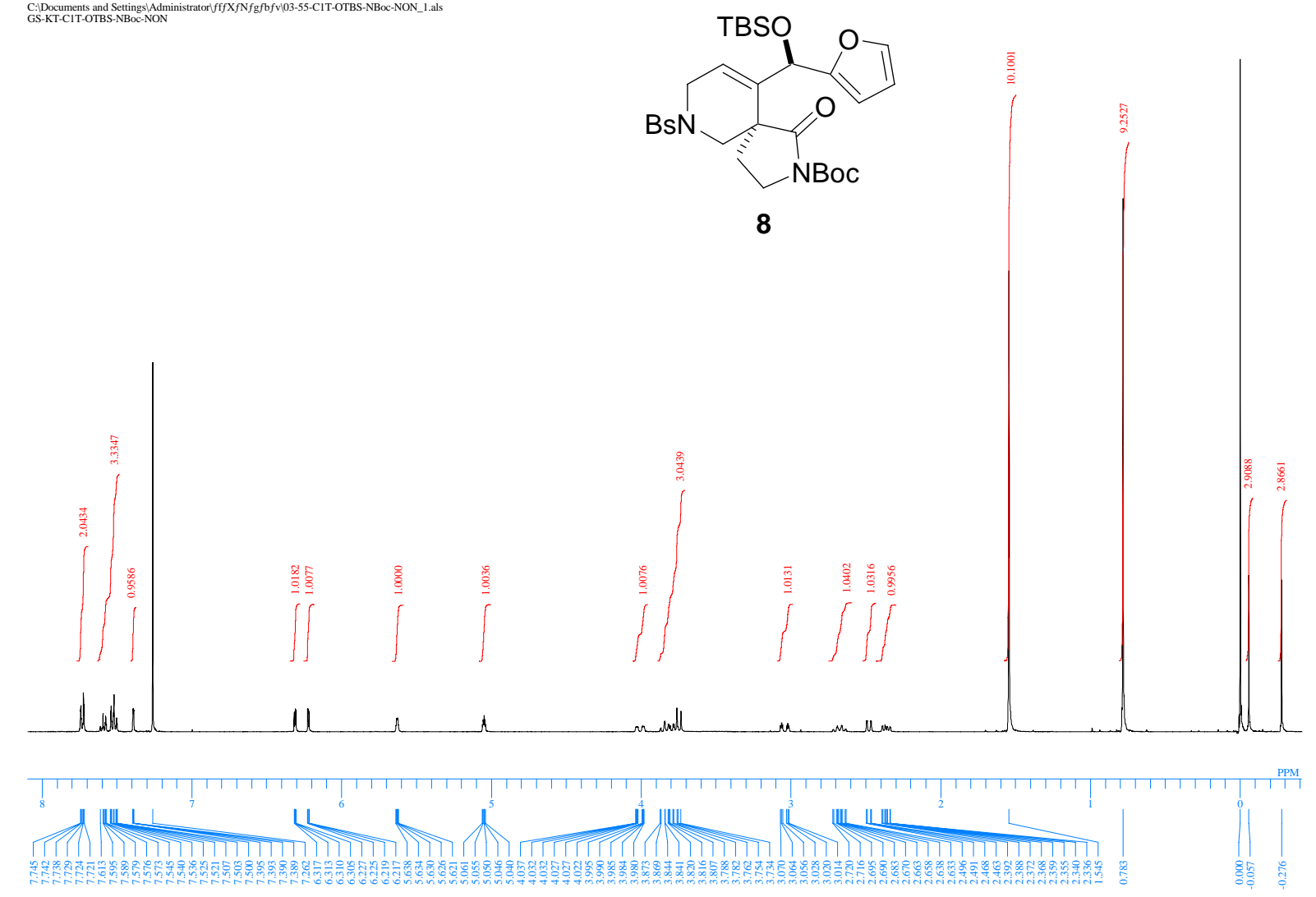

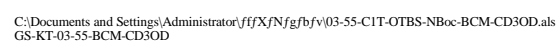

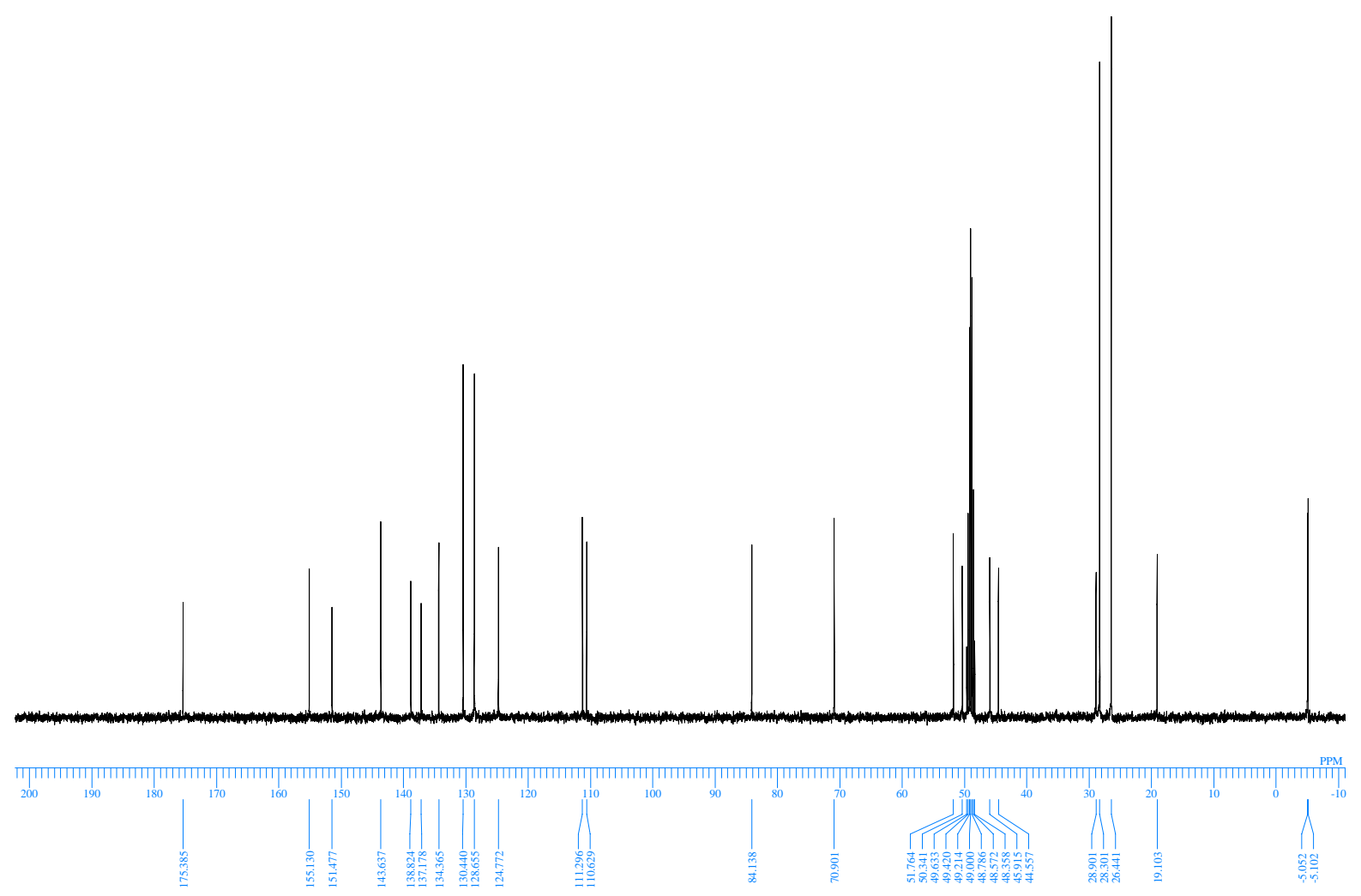




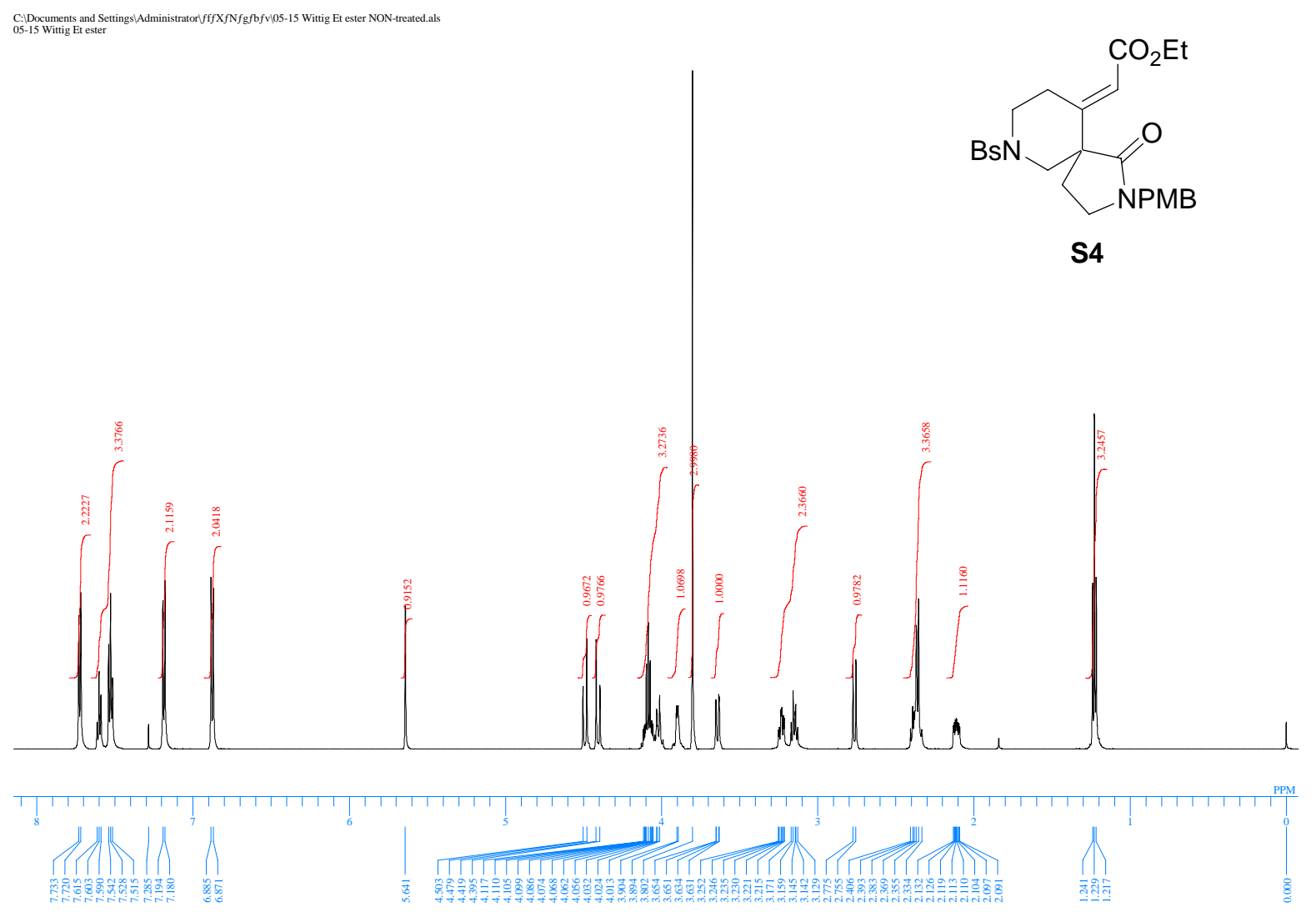

C.:Documents and Settings idministratorifff XfNffgfbfvio5-15 Witig Et ester BCM.als
$05-15$ Wititg Et ester BCM

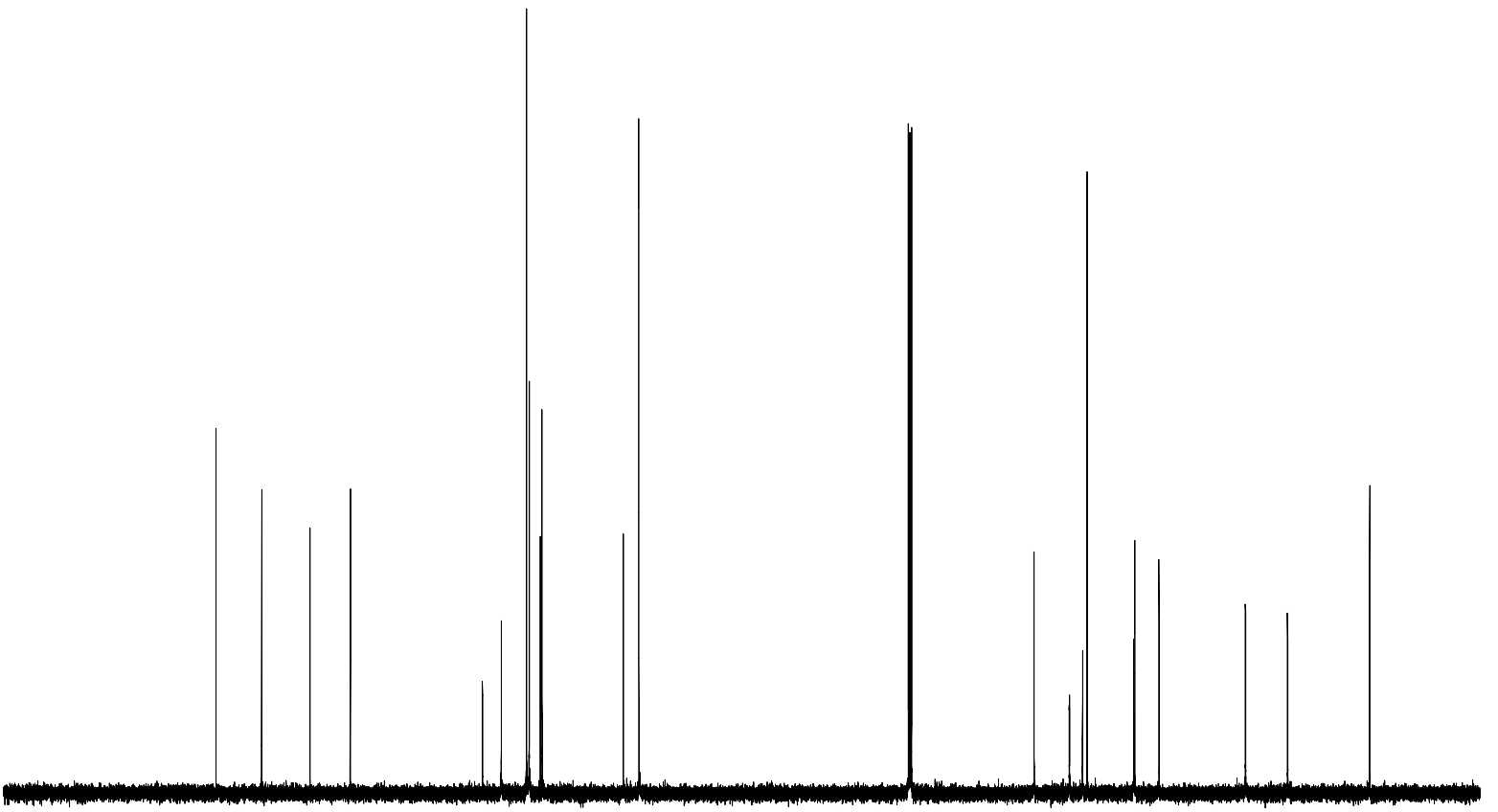

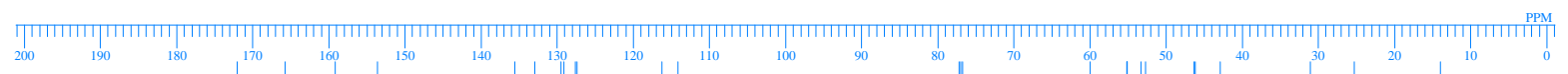

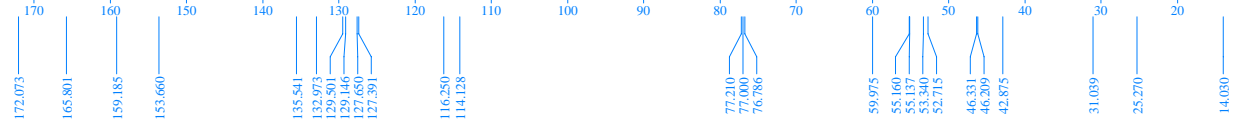




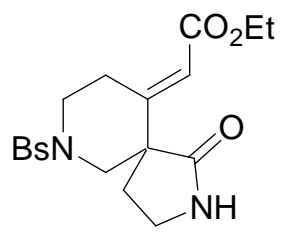

10

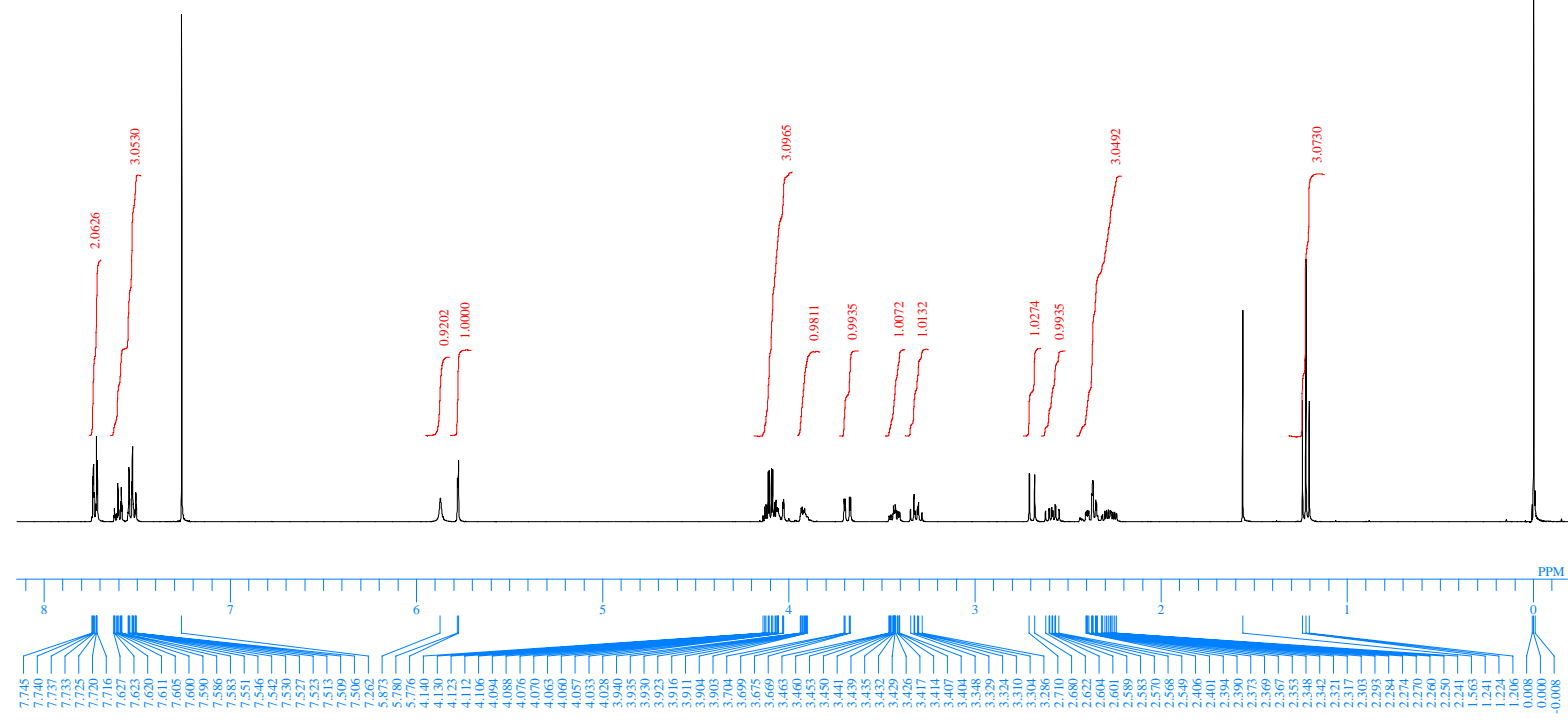

C:DDocuments and Settings 1 Administratorifff $\mathrm{X} f \mathrm{~N} f \mathrm{f} f \mathrm{f} f \mathrm{fv}$ V6-52-C2T-WITTIG-NH-BCM.als
GS-KT-C2T-WITTIG-NH-BCM

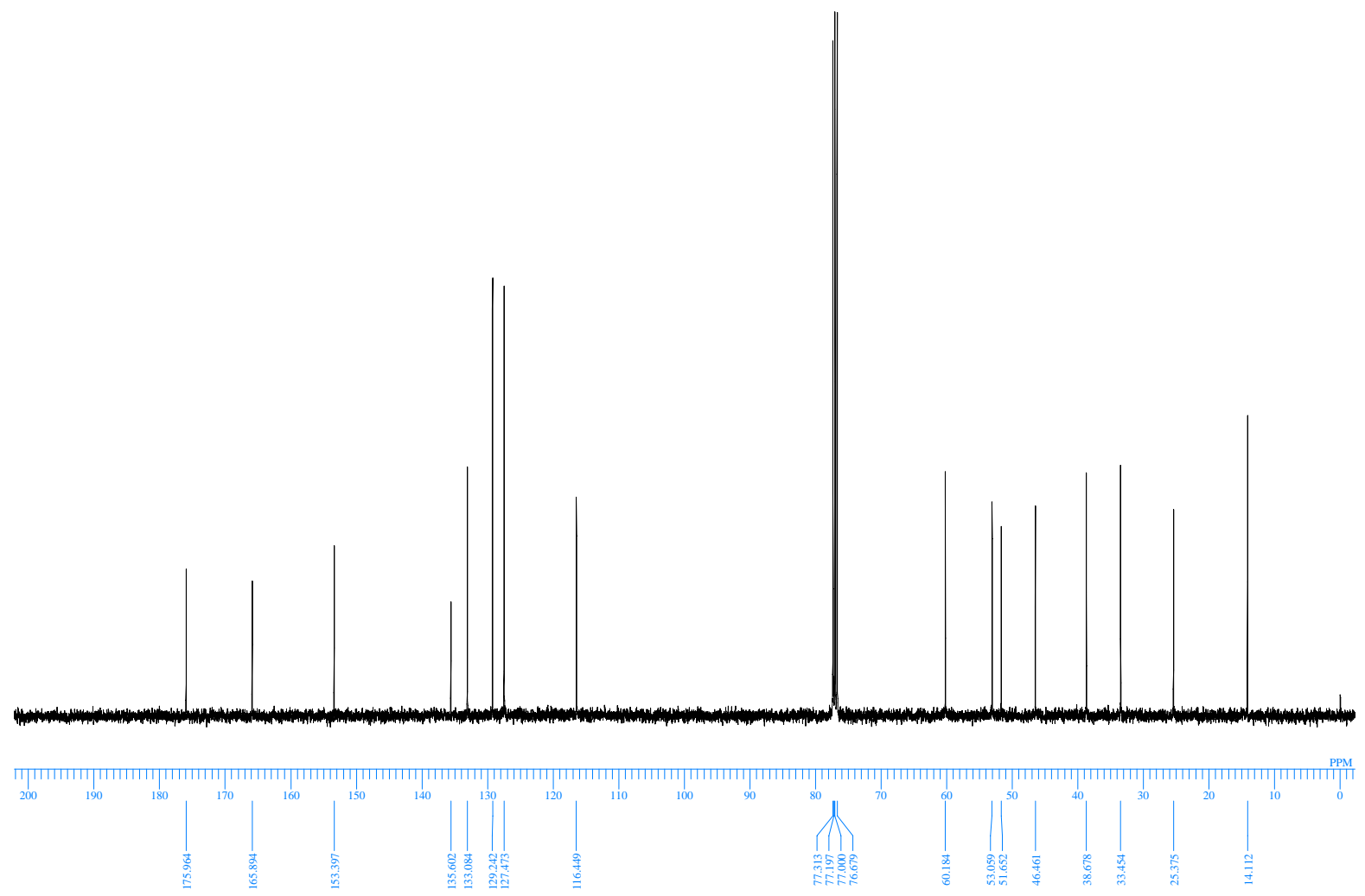




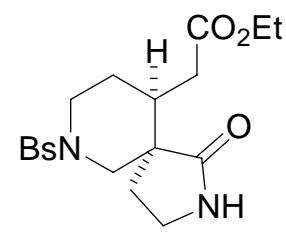

11
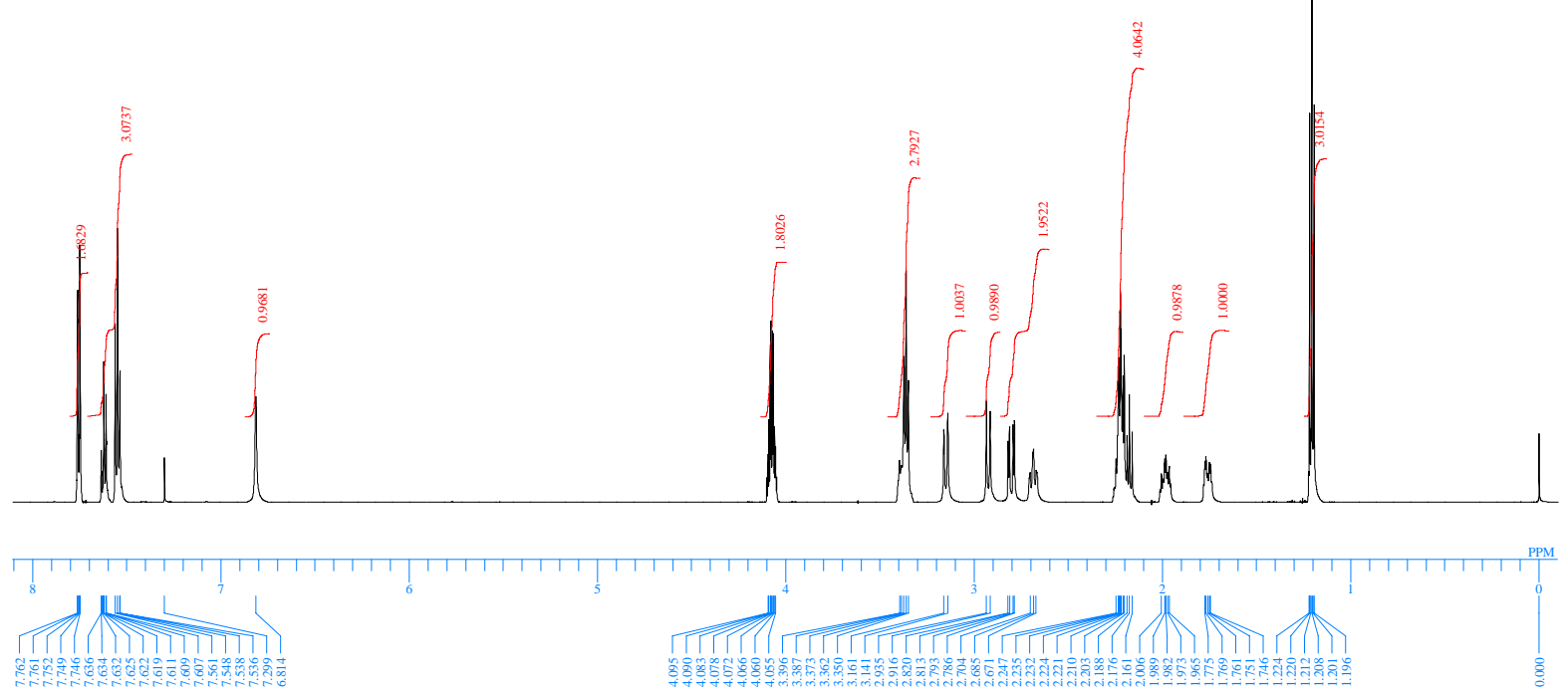

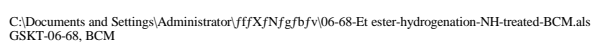

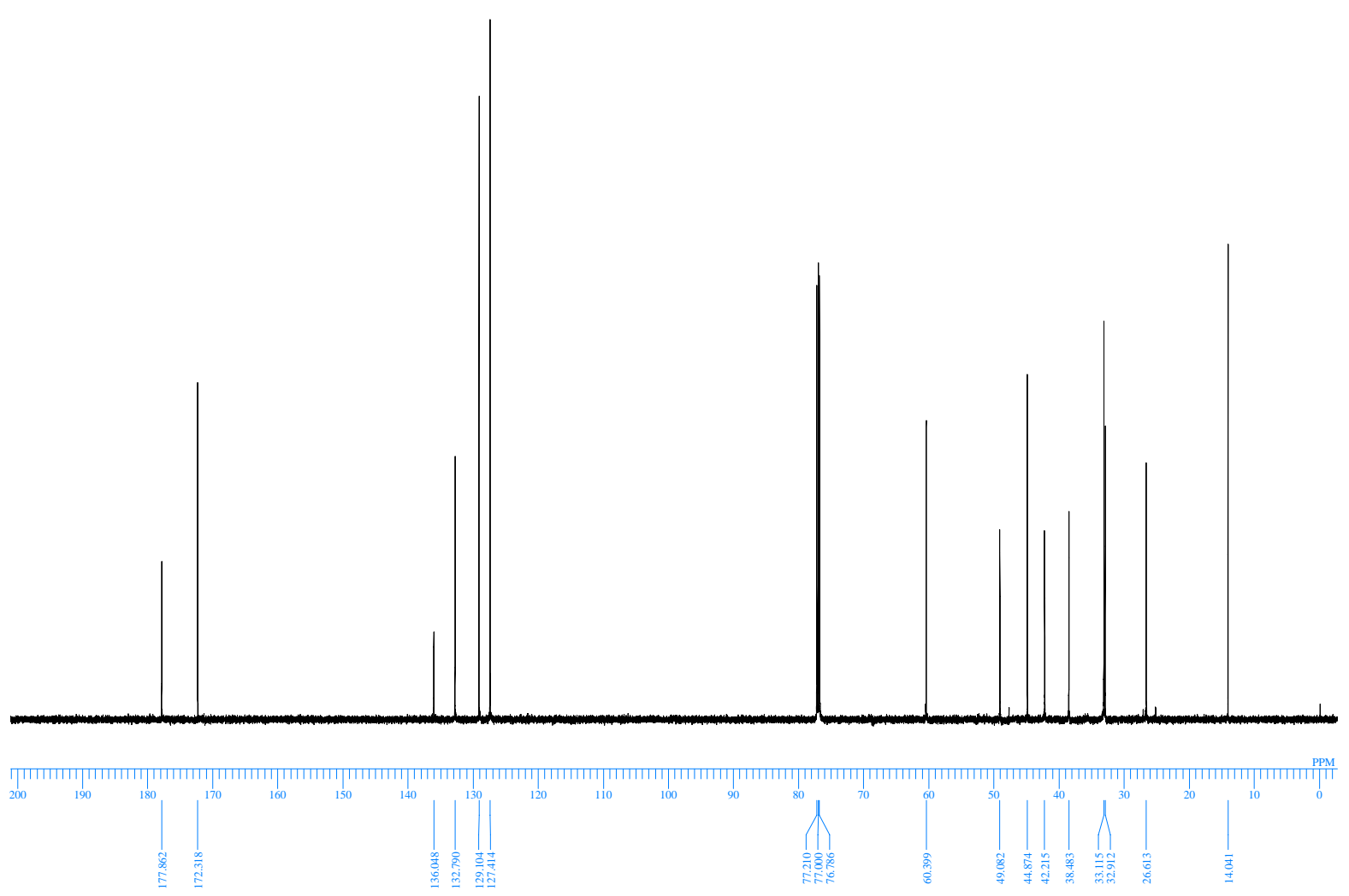




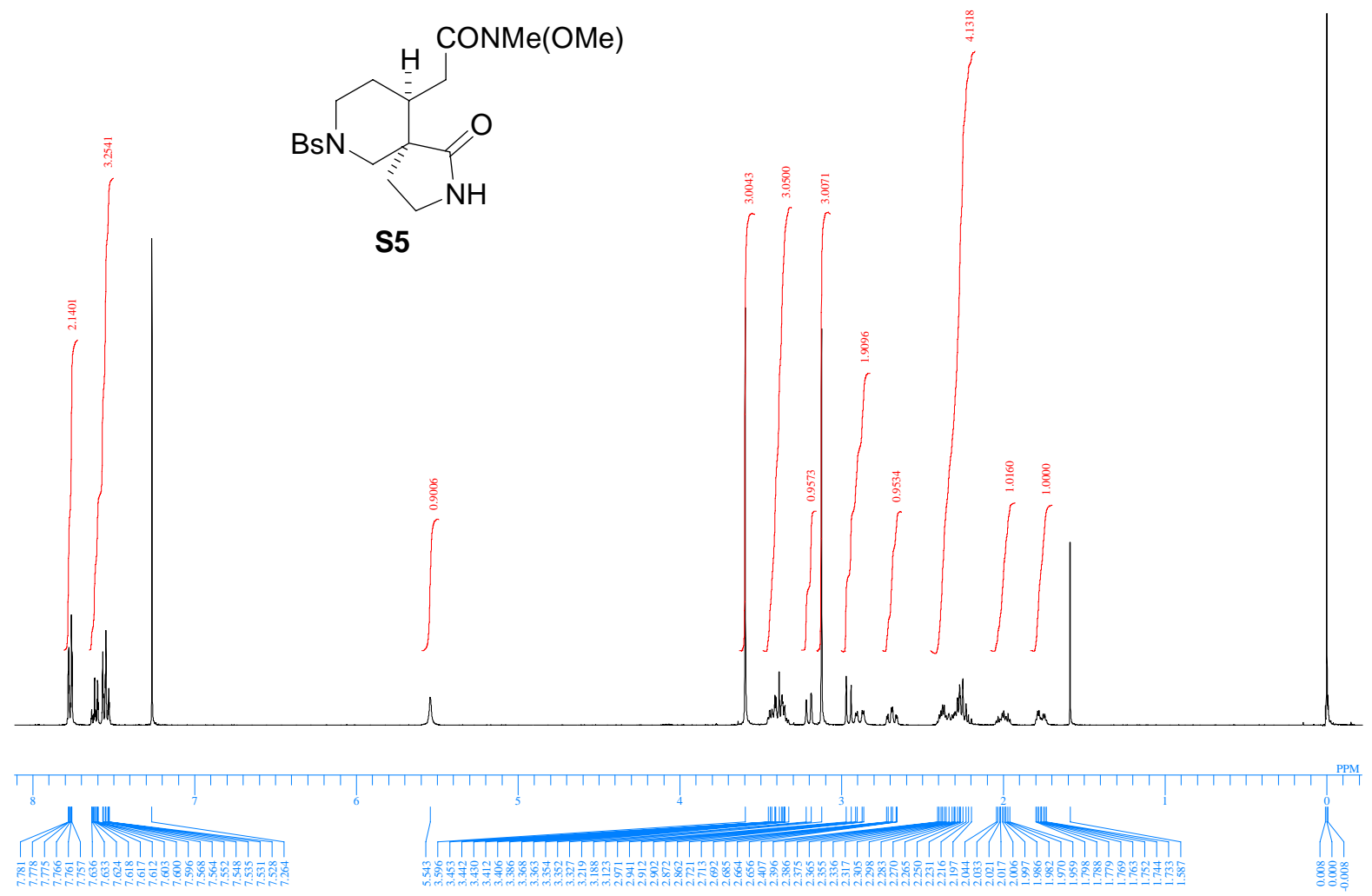

C:DDocuments and Settingsidadministratorffff $\mathrm{X} f \mathrm{~N} f \mathrm{gfb} f \mathrm{f}$ V07-76-C2T-Weinreb-BCM.als
GS-KT-C2T-Weinreb-BCM2

W.

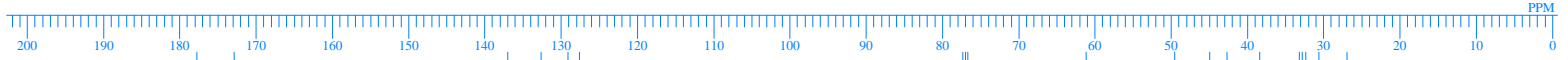

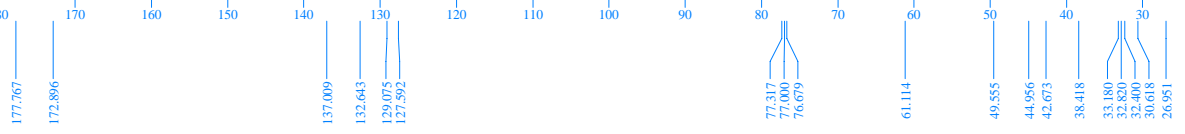




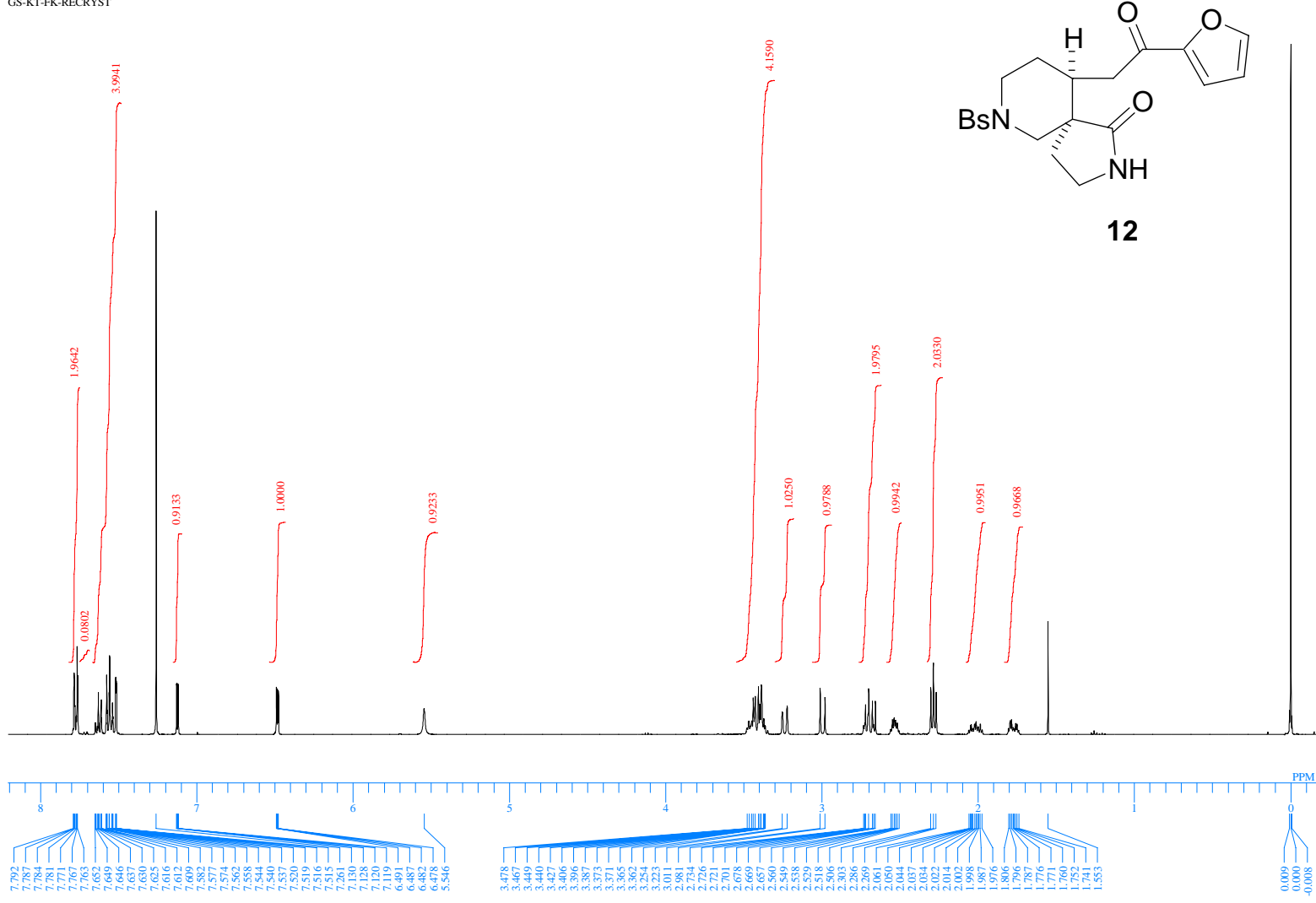

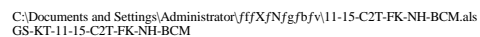

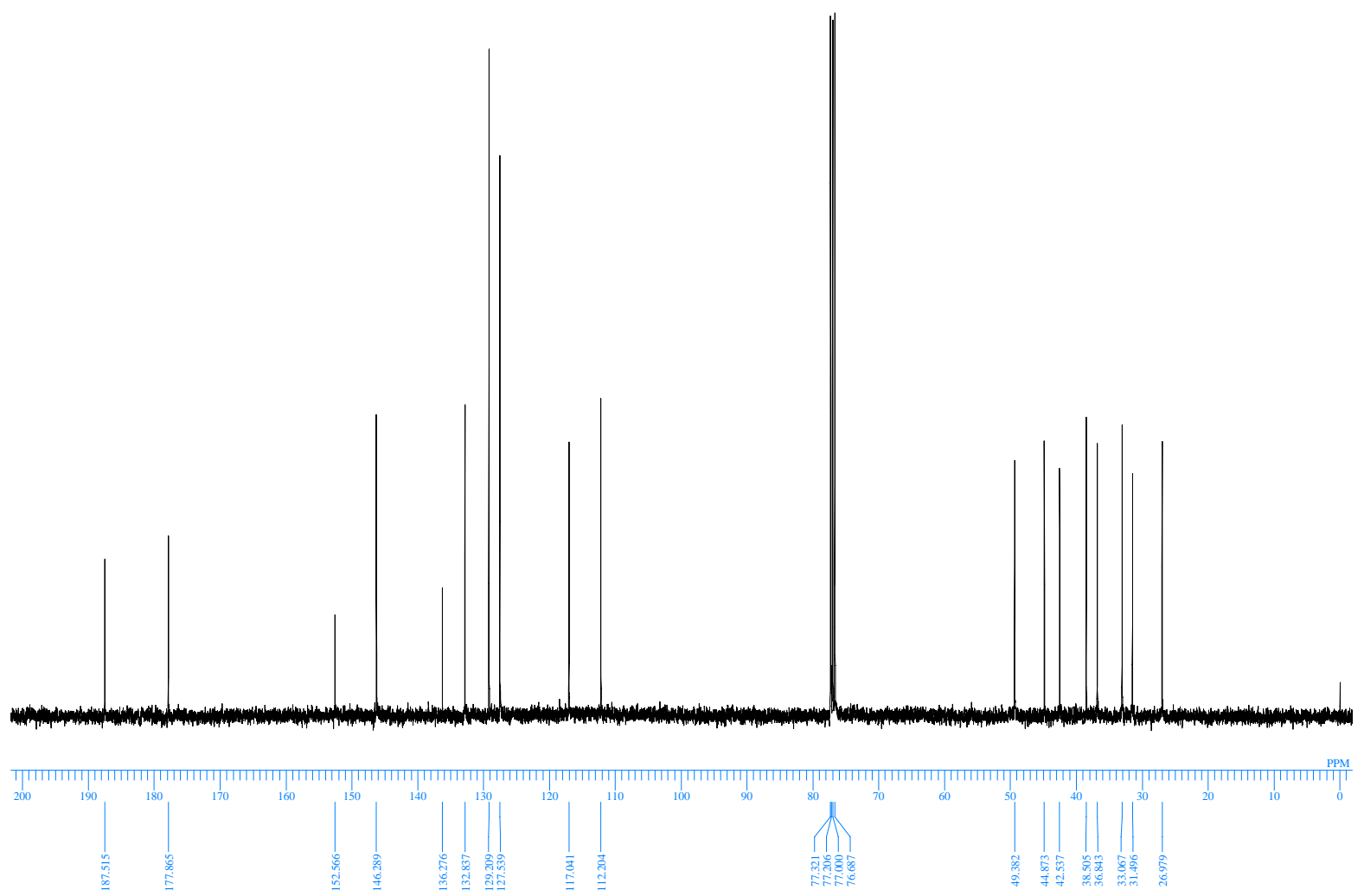



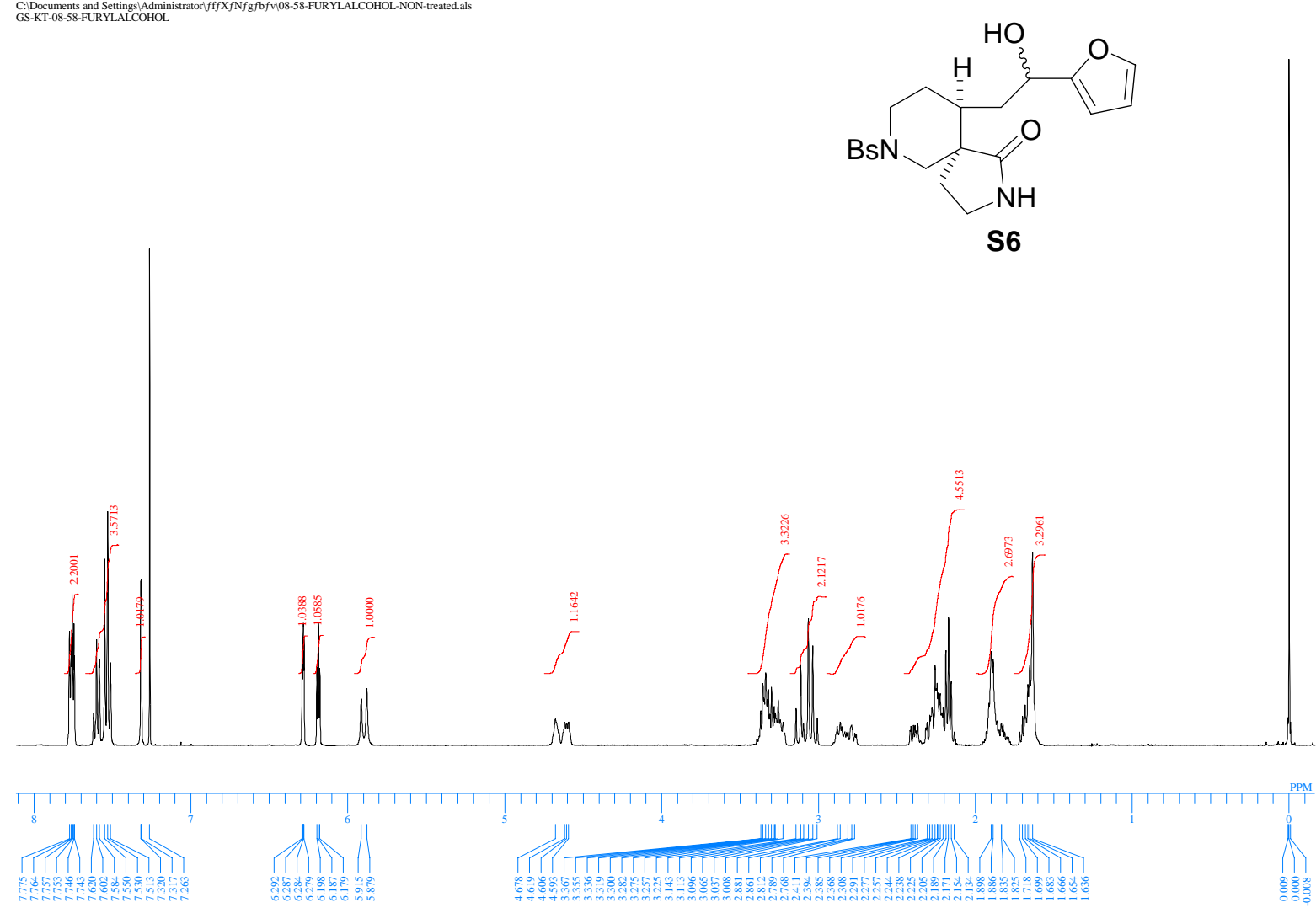

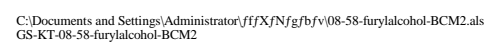

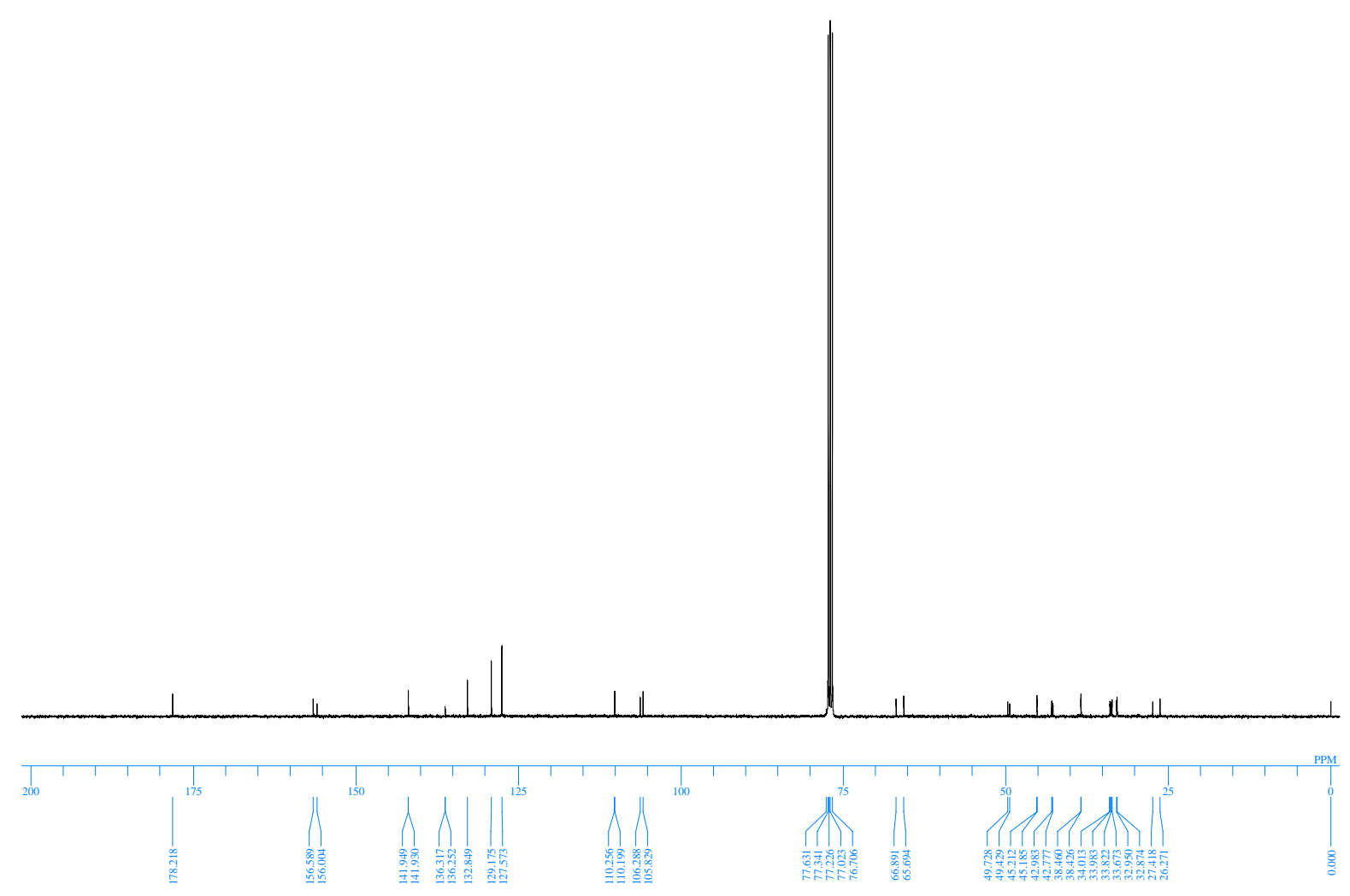




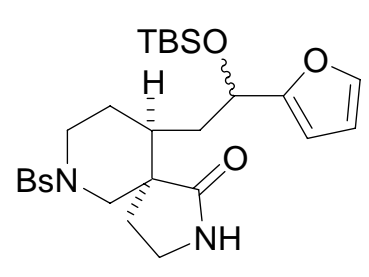

S7

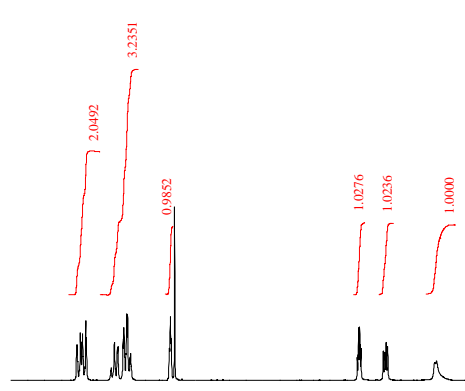
w winth
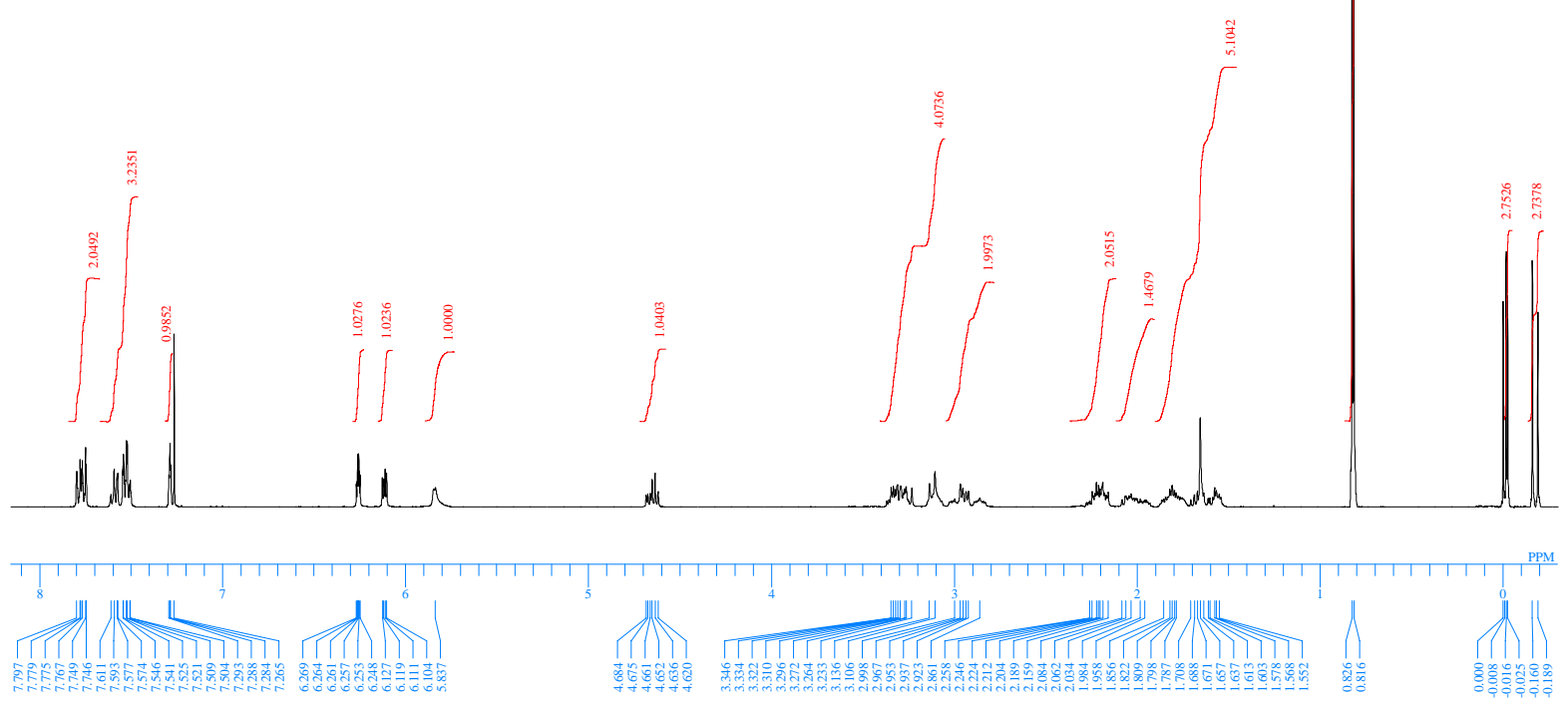

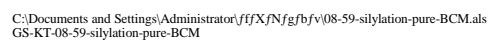

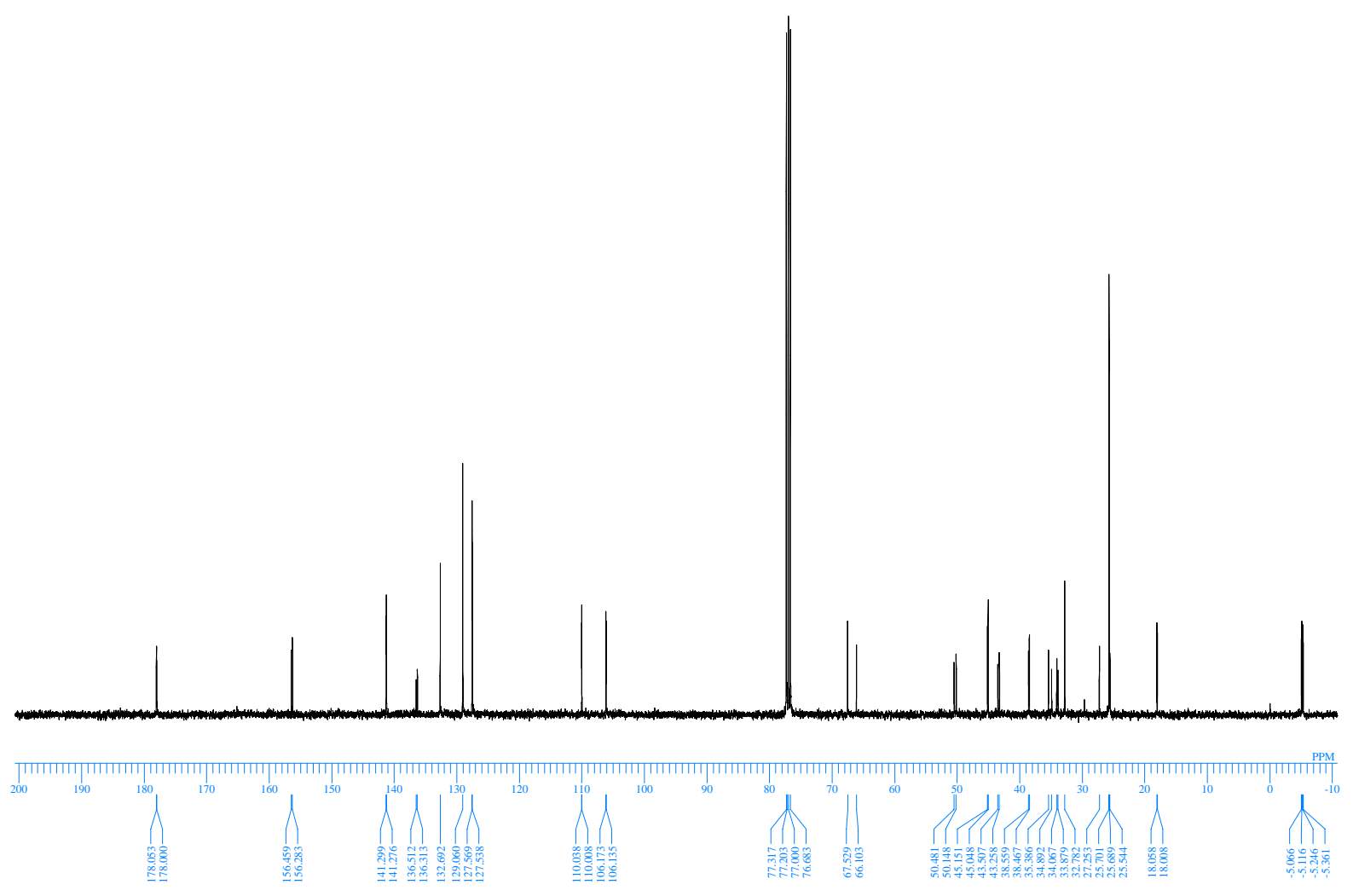



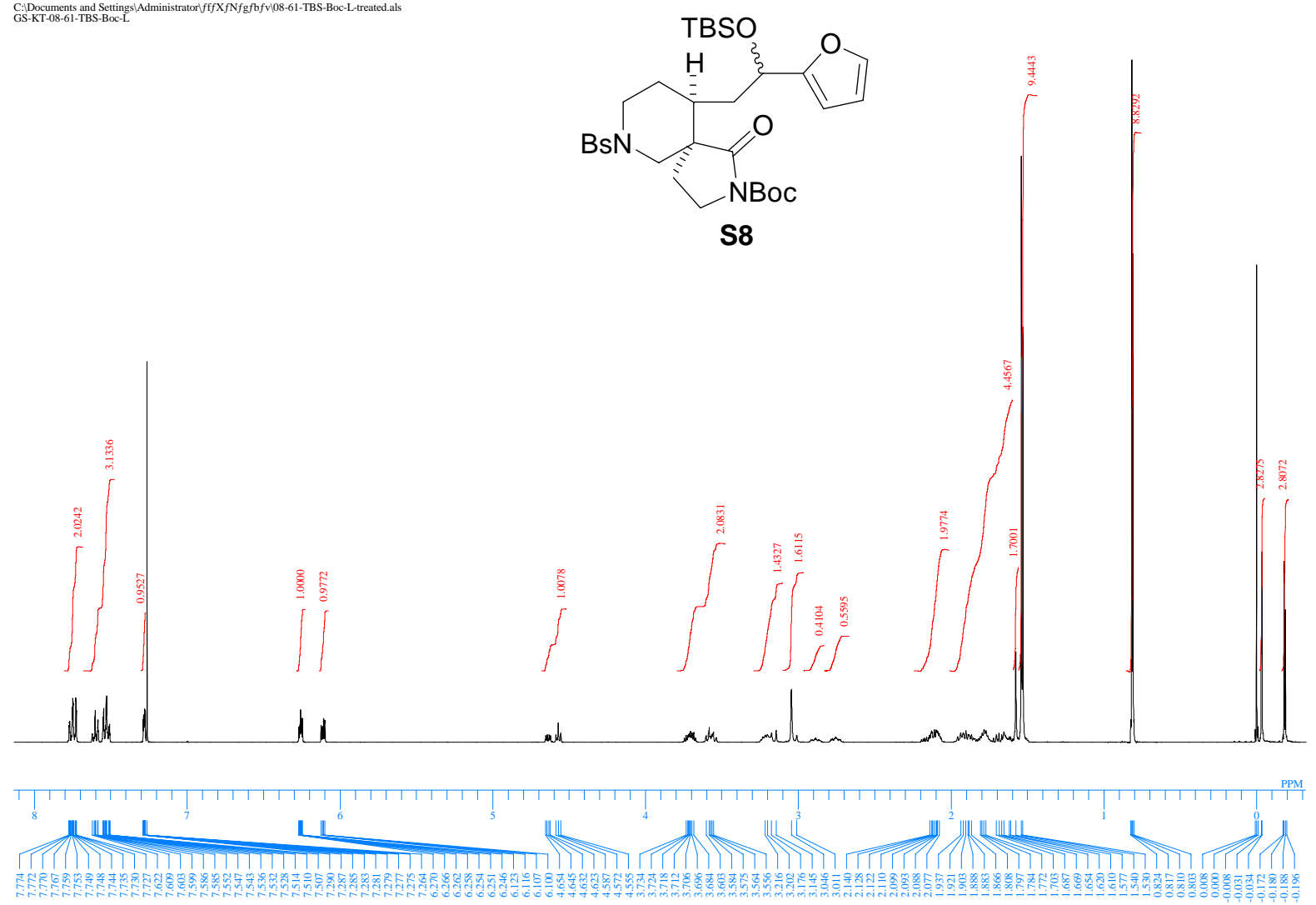

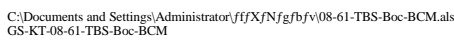

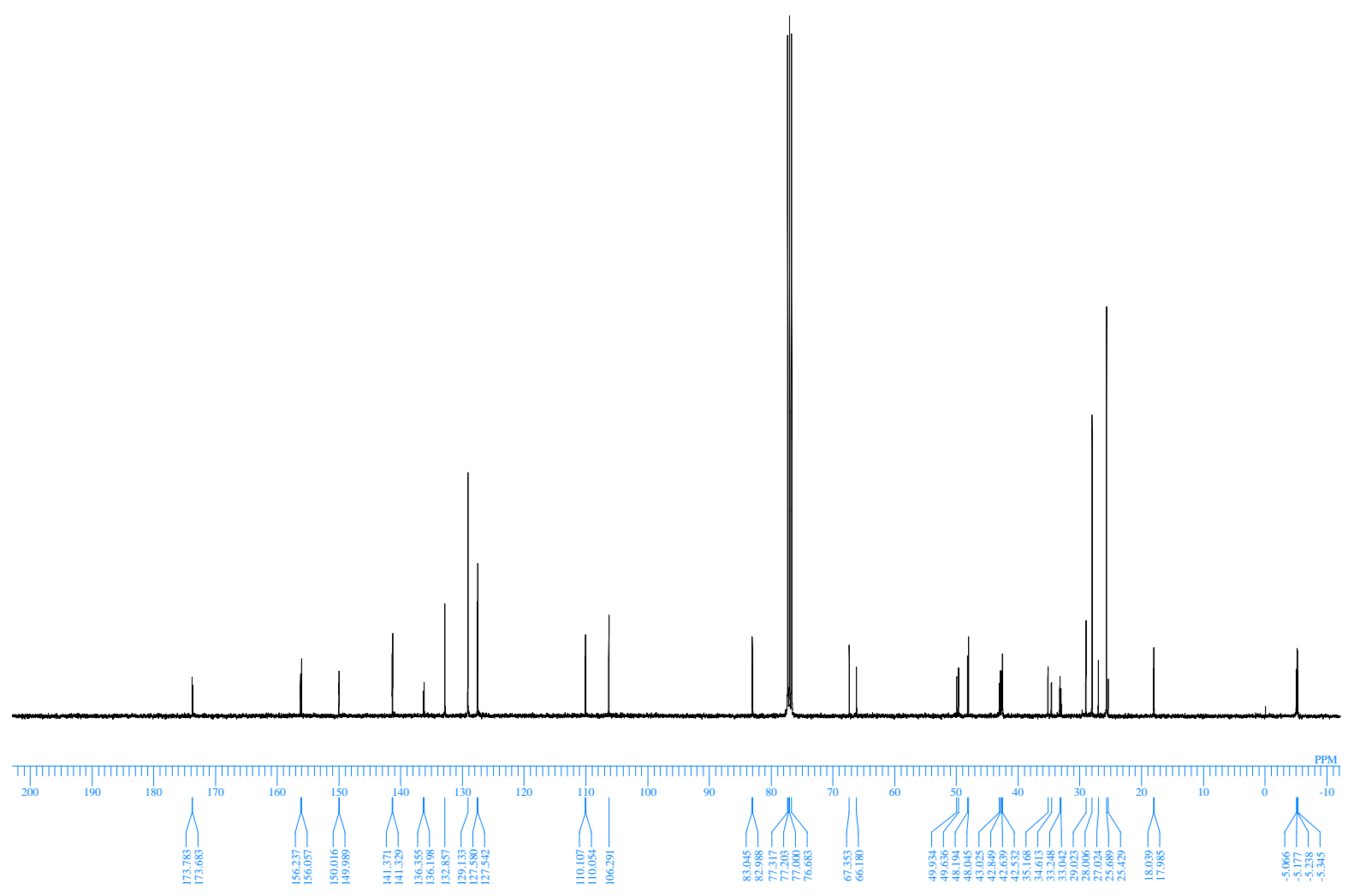




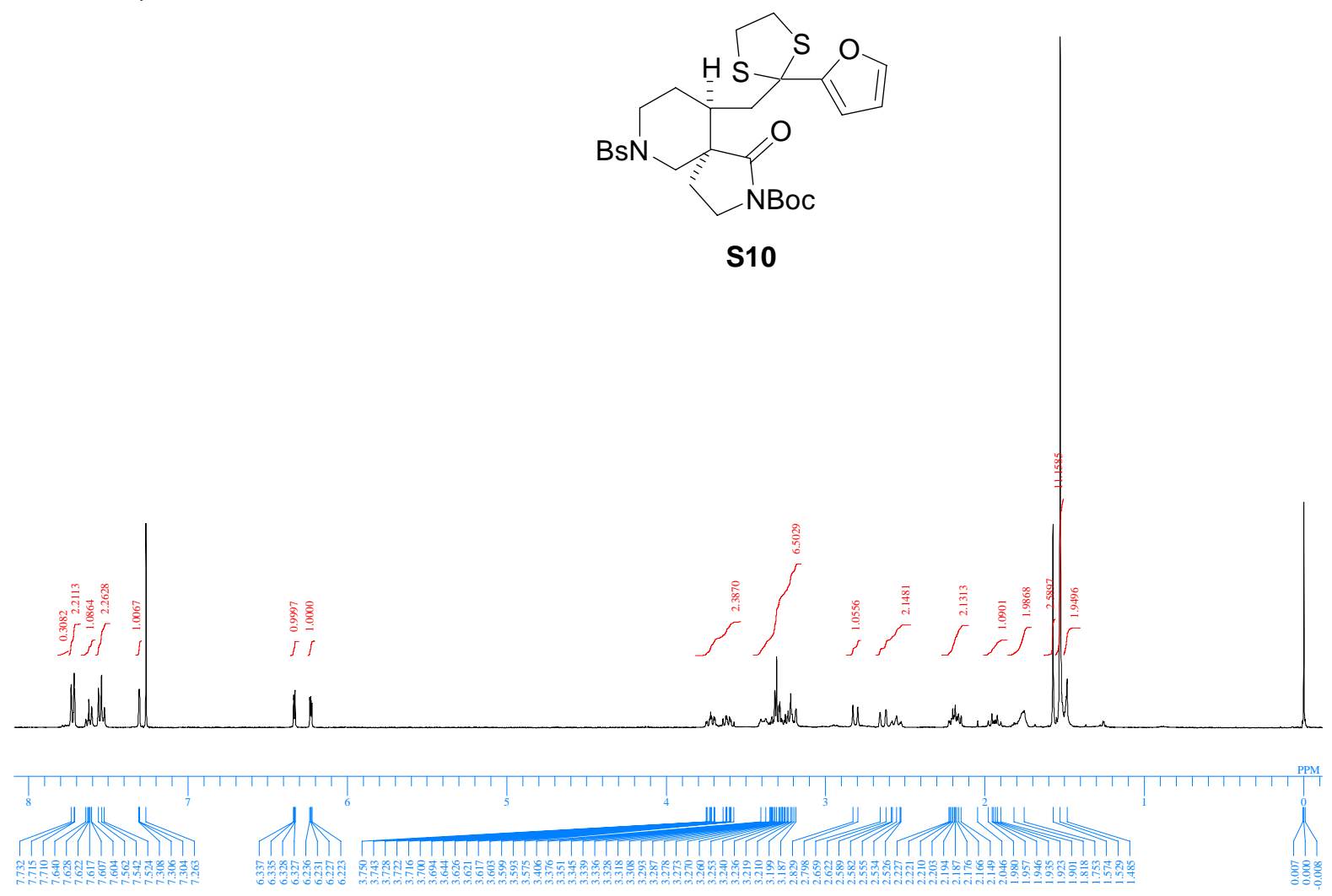

C:Documents and Settings SAdministratoriff $f$ X $f$ Nffffbfvi07-63-C2T-H2THIO-NBOC-BCM.als
GS-KT-C2T-H2THIO-NBOC-BCM

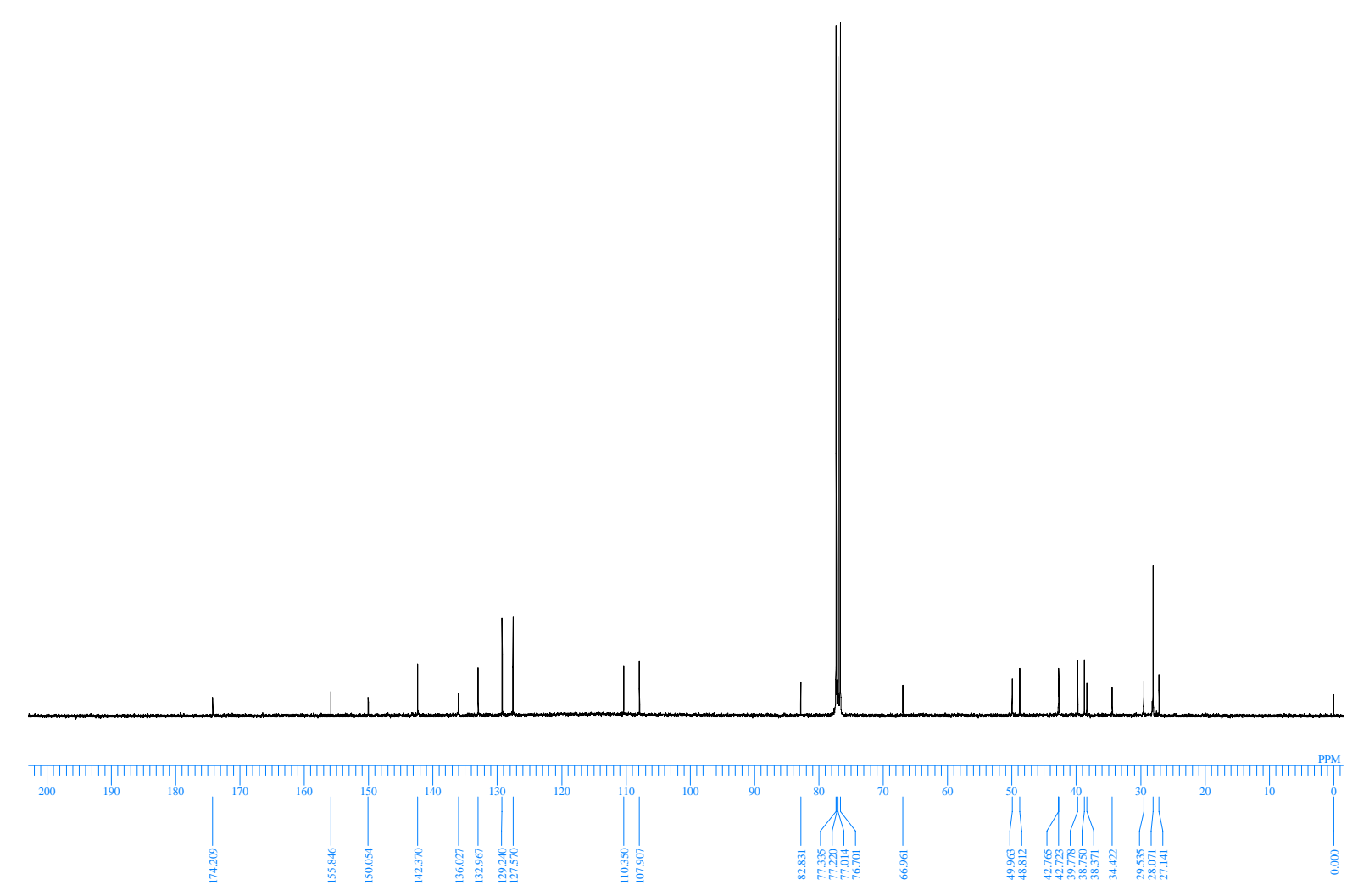




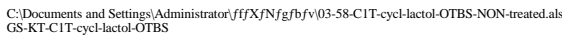

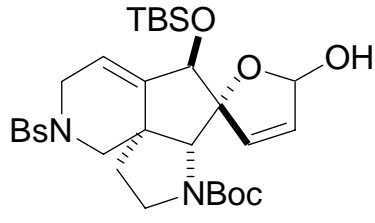

15

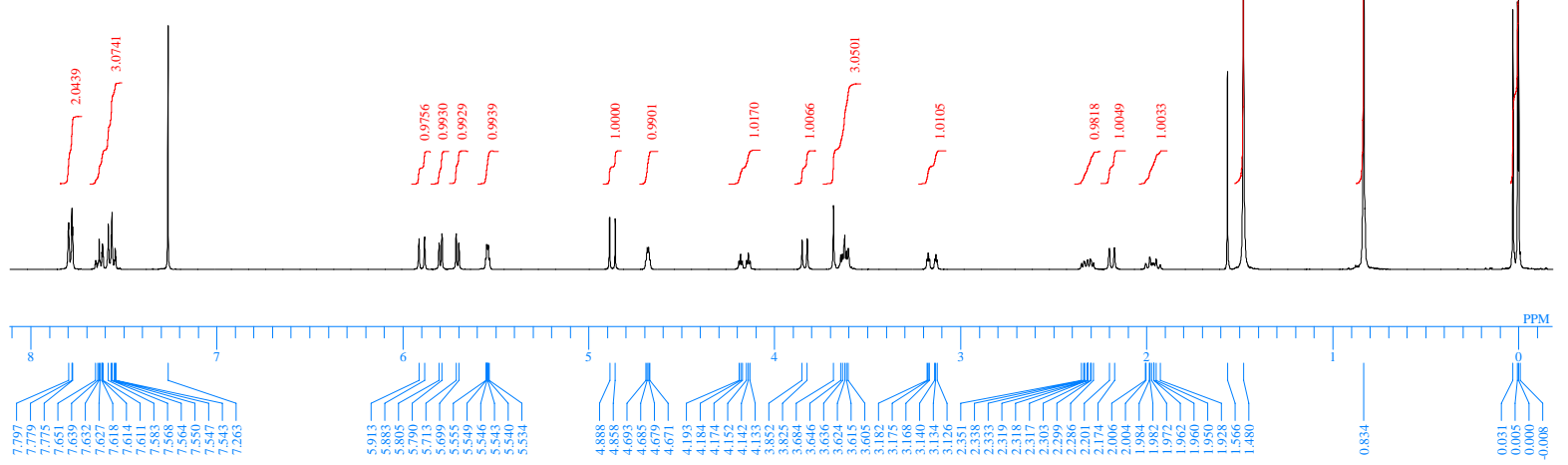

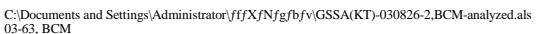

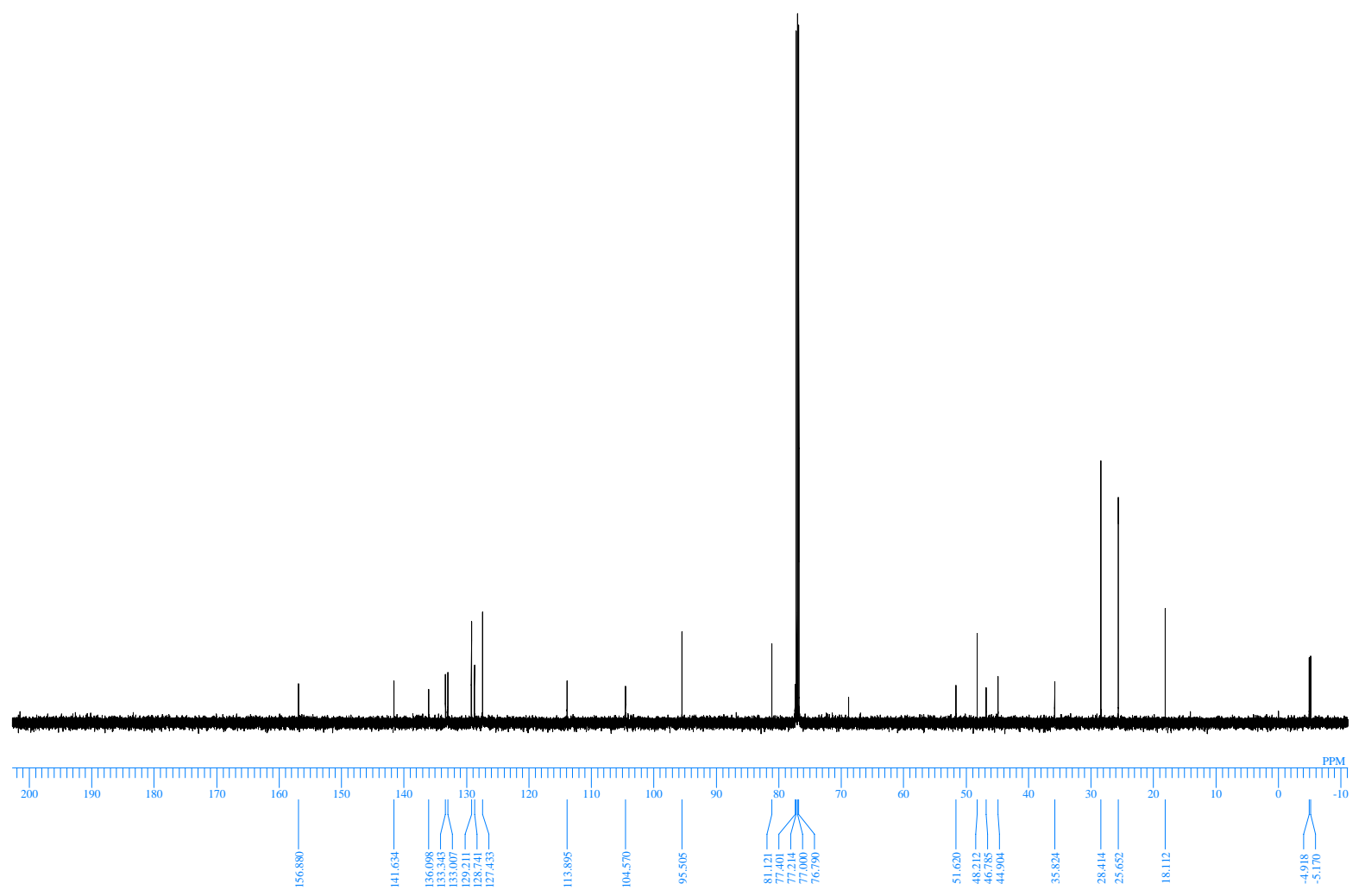




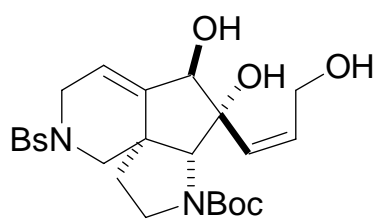

16

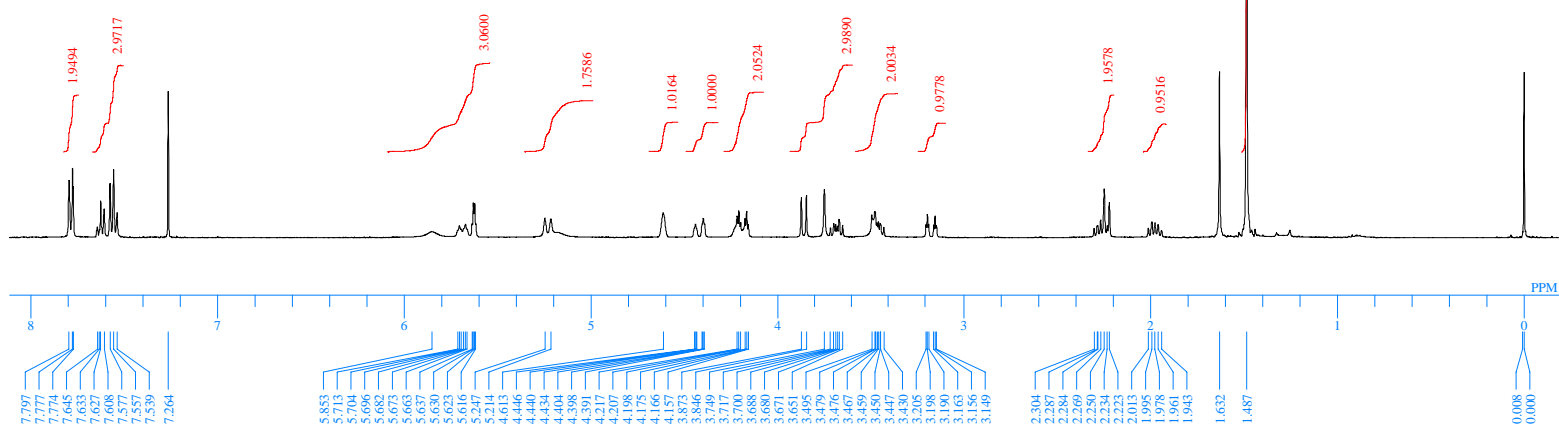

C:DDocuments and Settings IAdministrator If $f$ X $\mathrm{X} f \mathrm{~N} f \mathrm{ffb}$ fvi:05-33-C1T-TRIOL-BCM.als
GS-KT-CIT-TRIOL-BCM

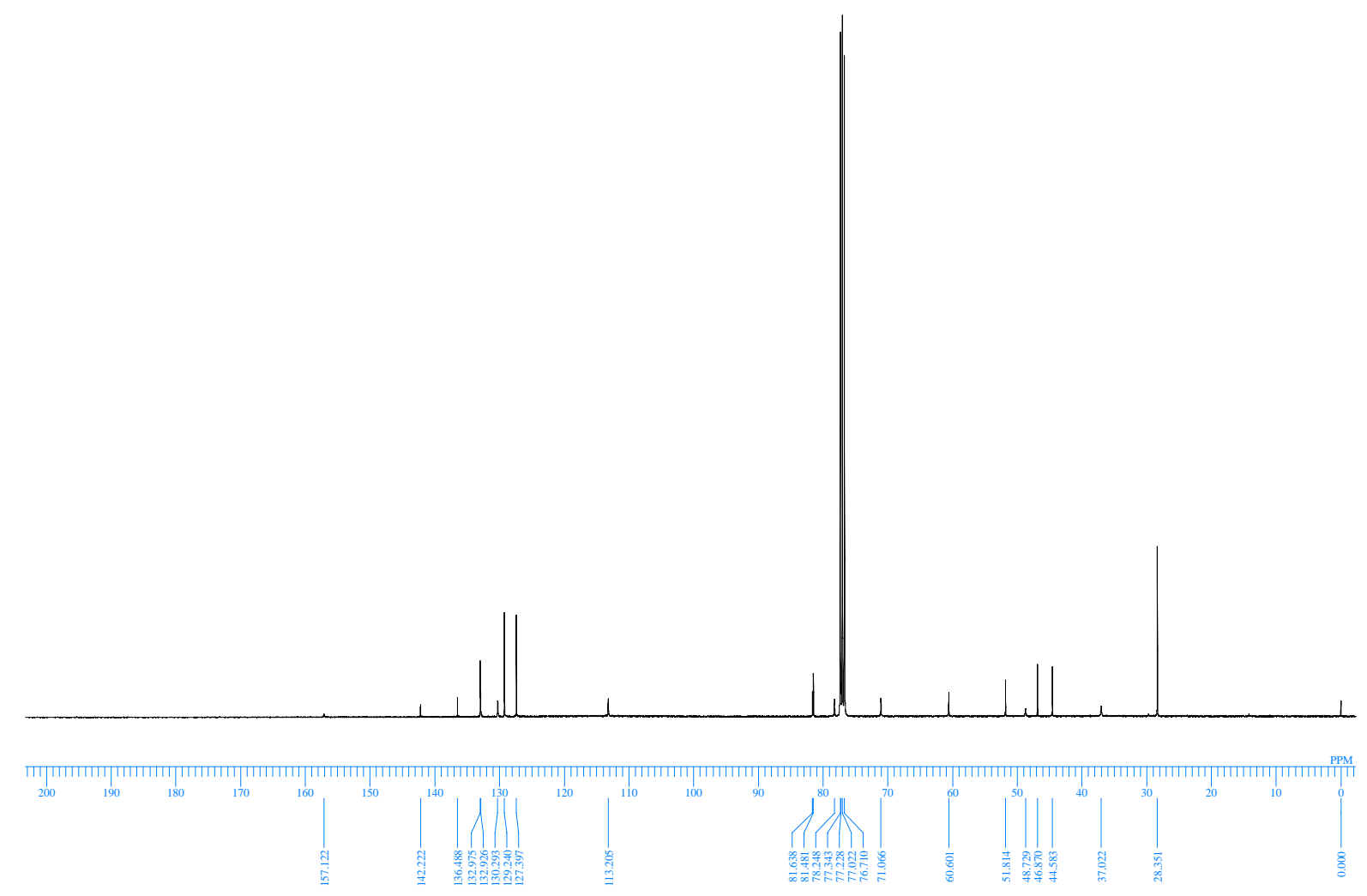




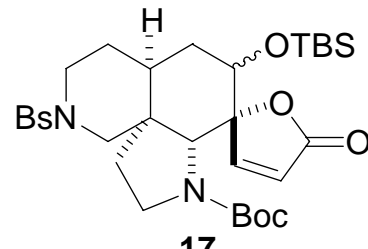

17

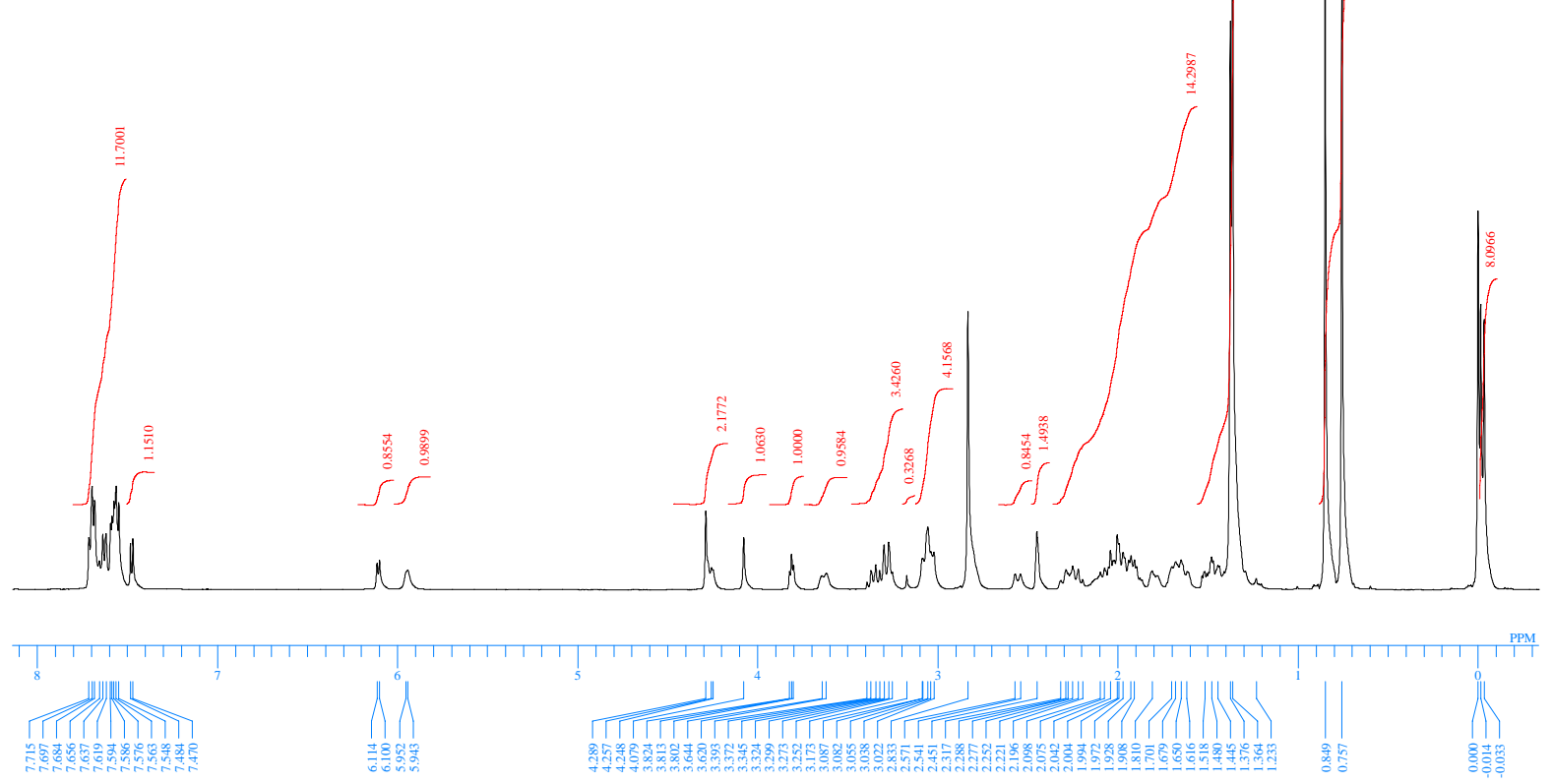

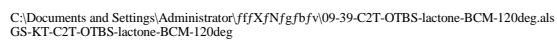

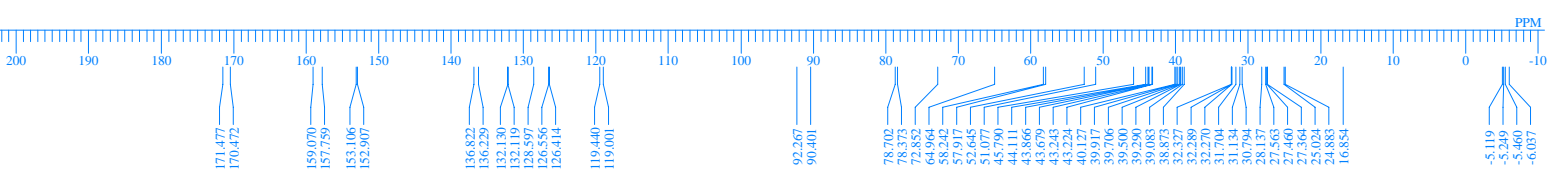




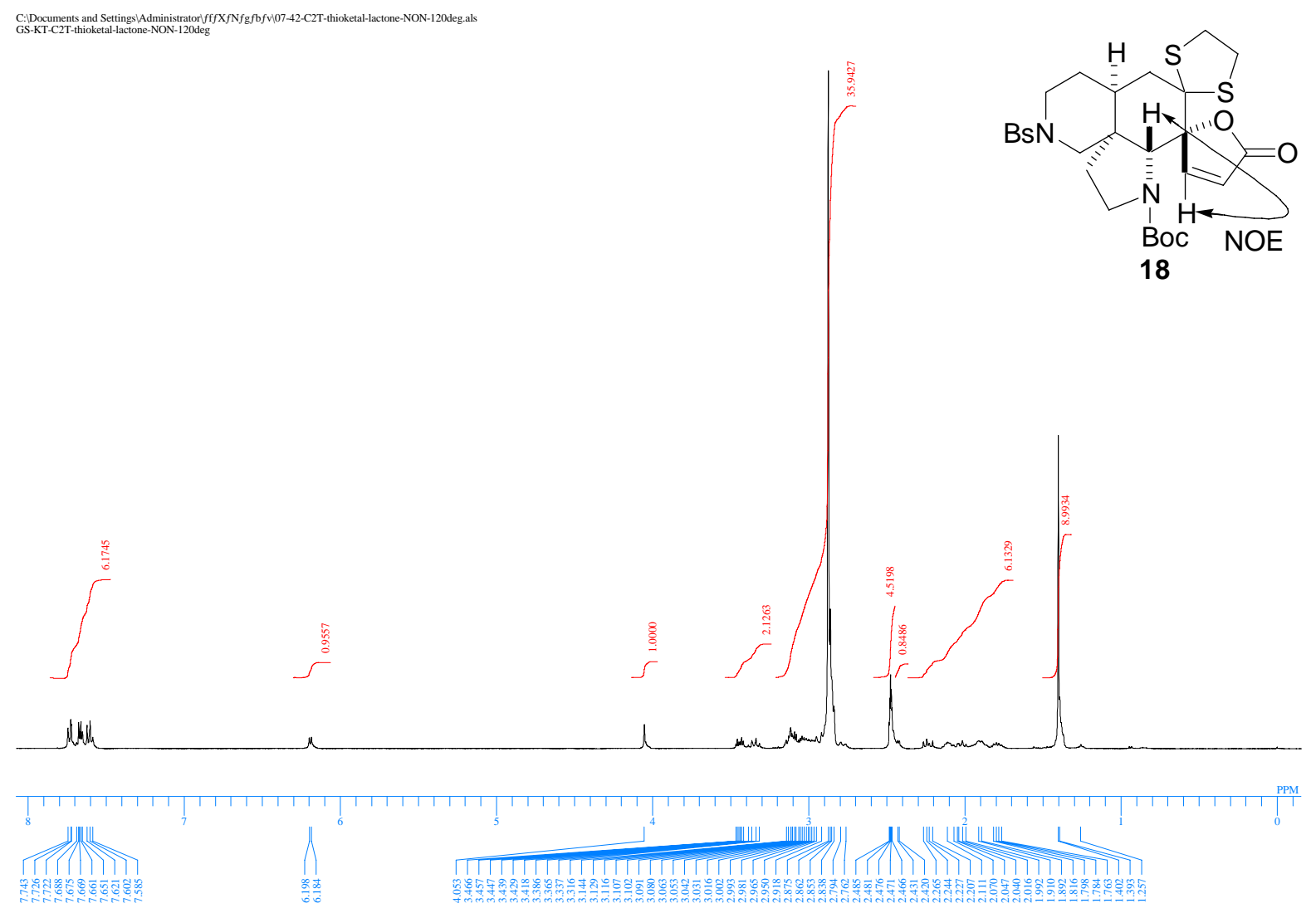

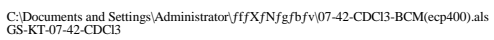

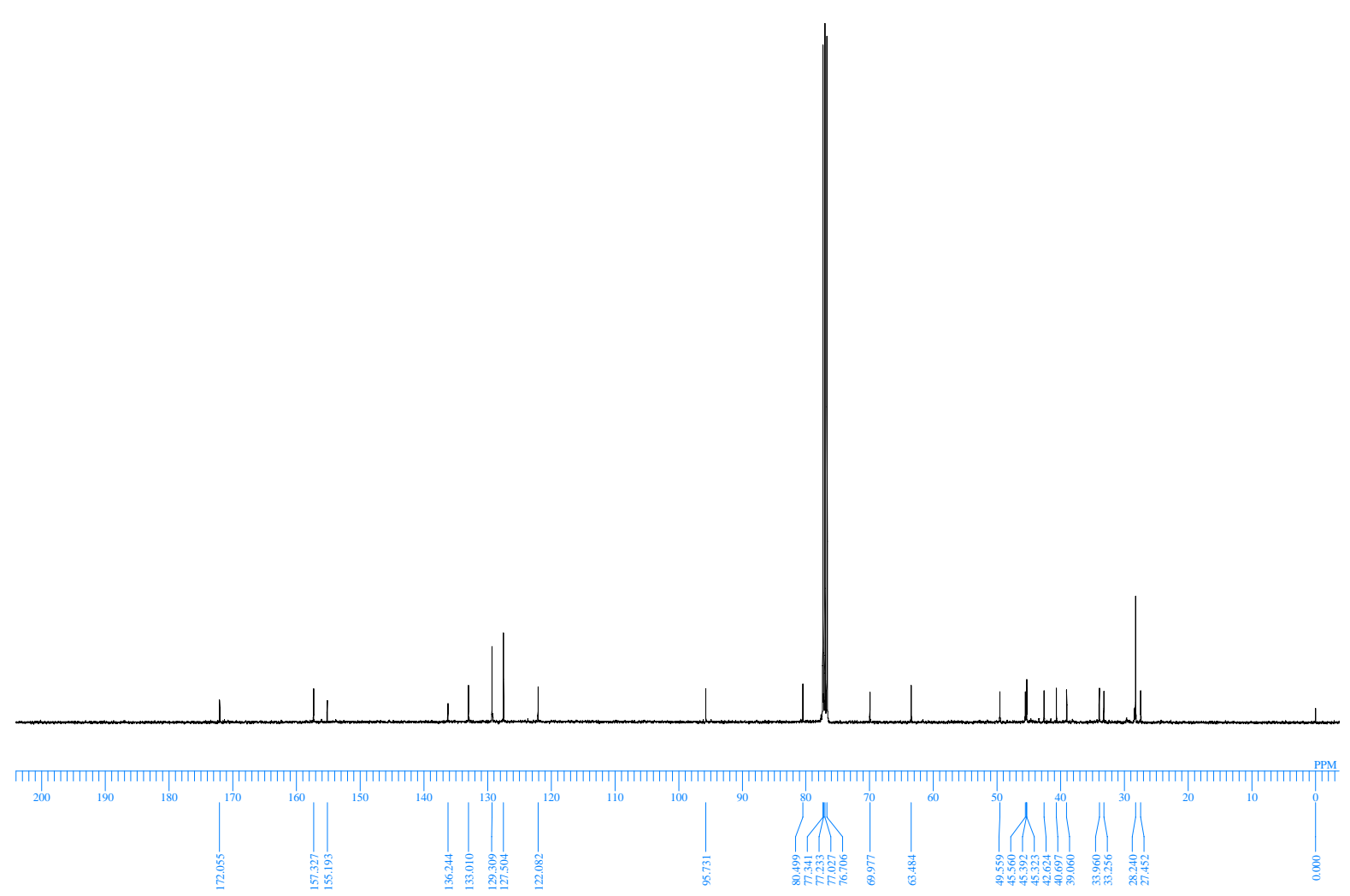




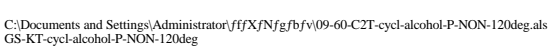

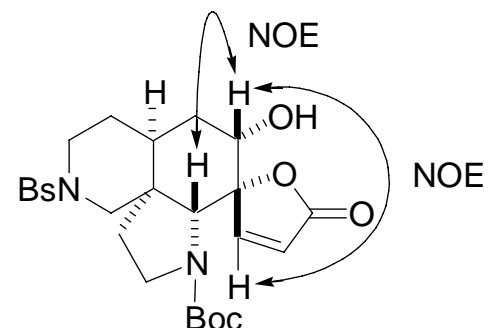

$\mathrm{S} 12(\alpha-\mathrm{OH})$

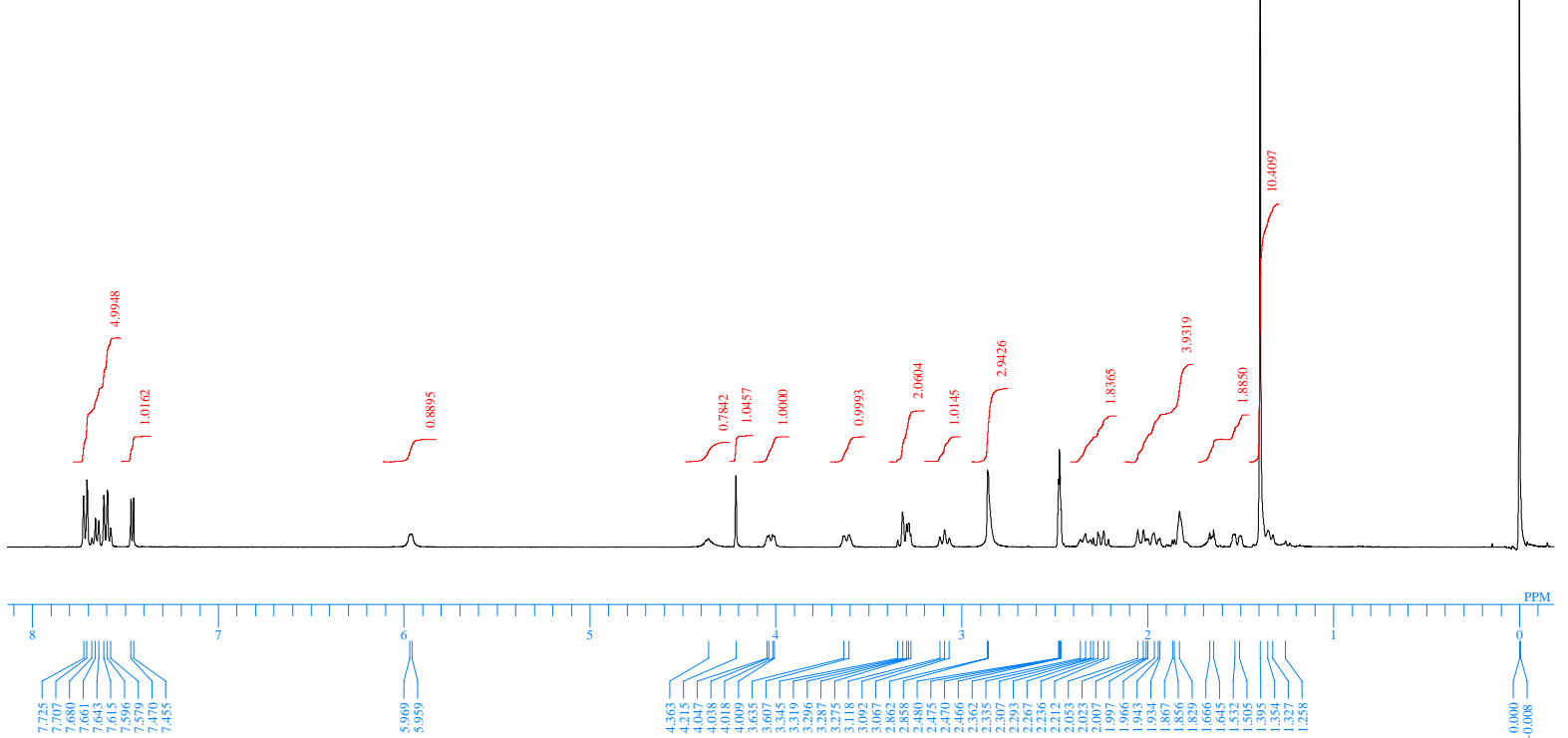

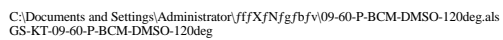

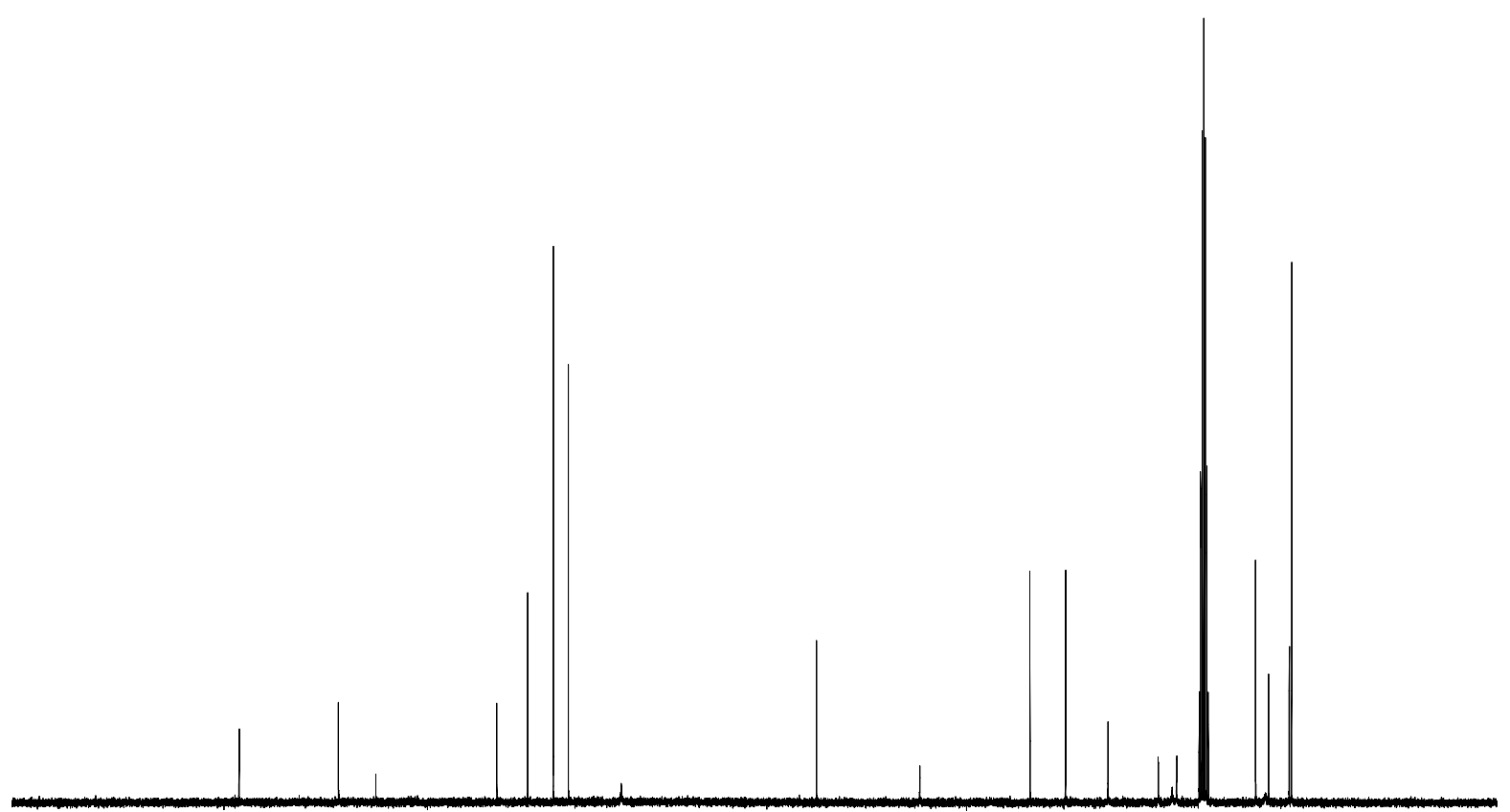

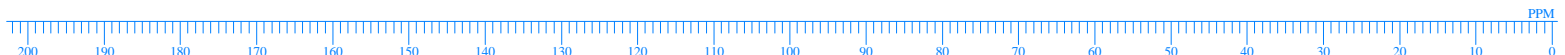

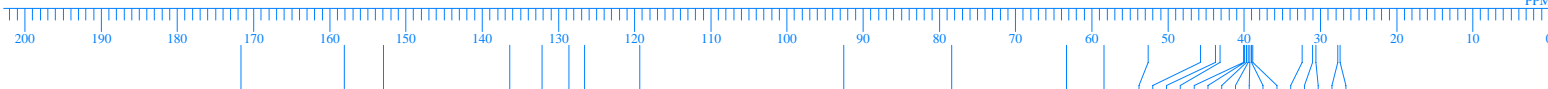

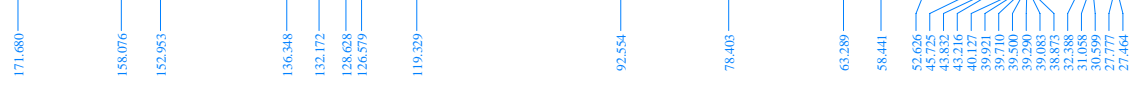




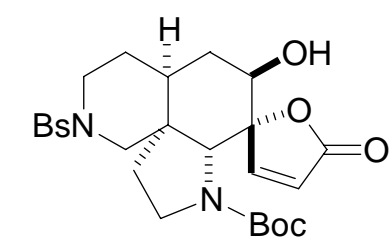

S12 ( $\beta-\mathrm{OH})$

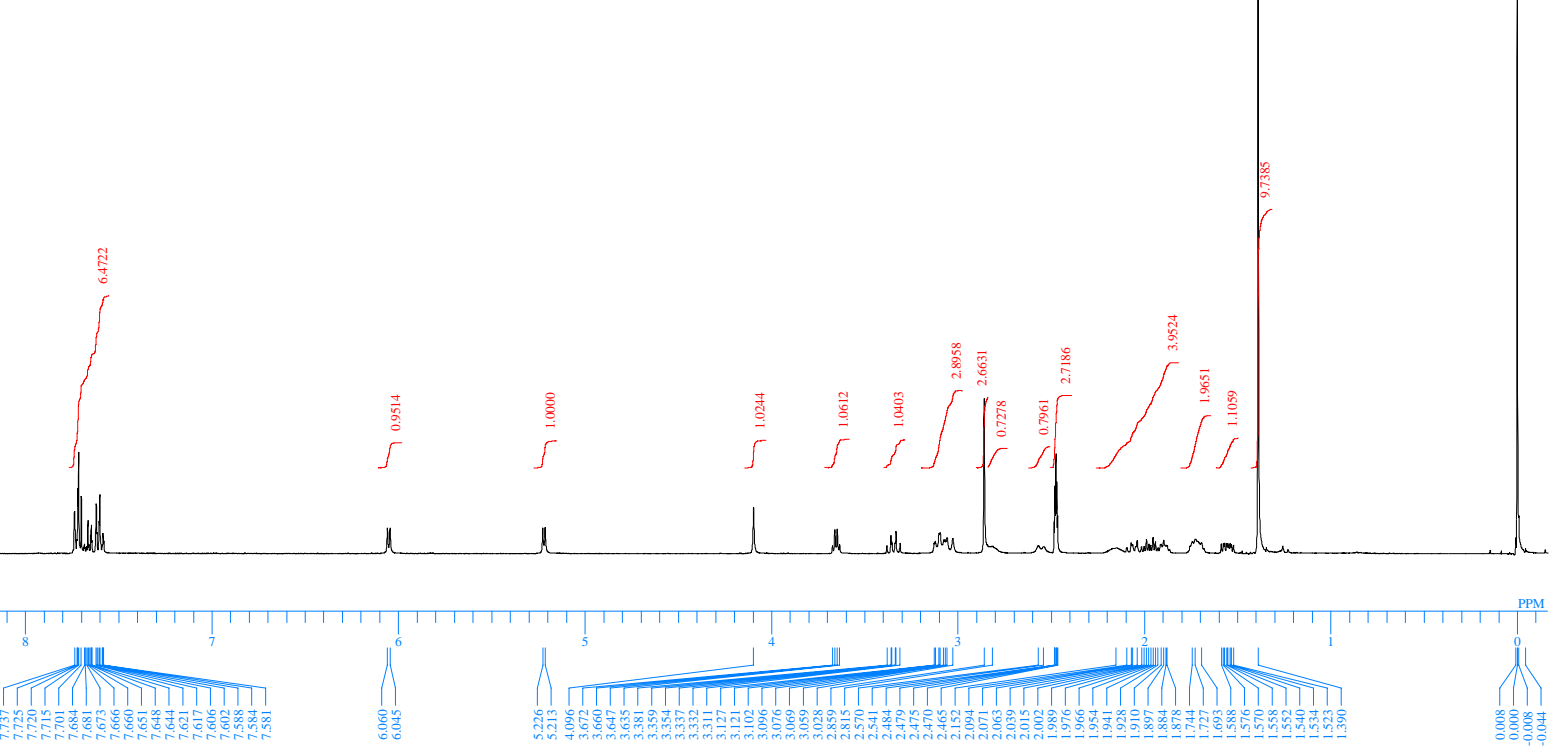

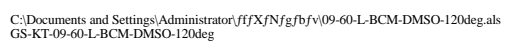

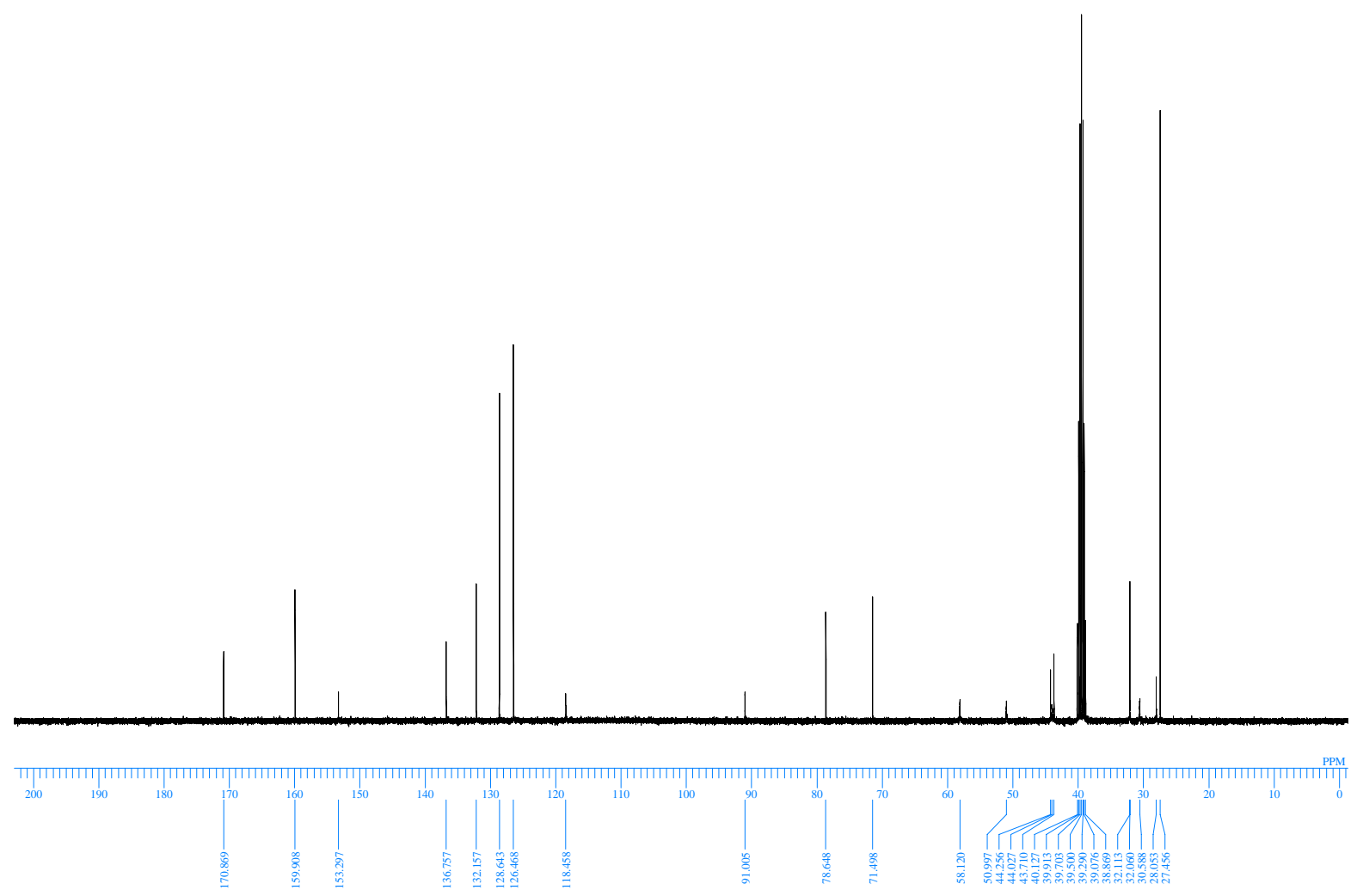




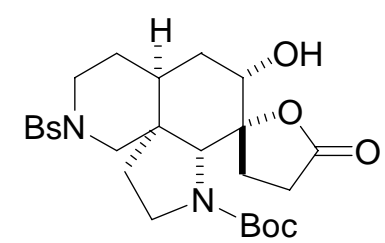

$19 a$
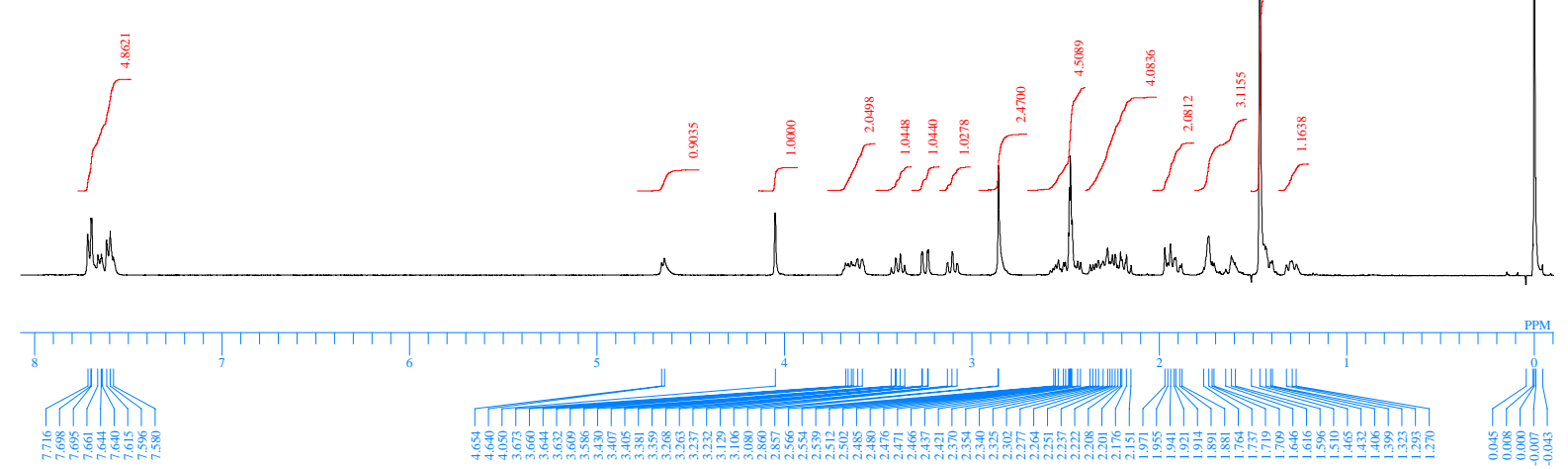

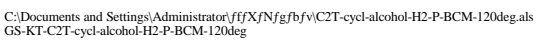

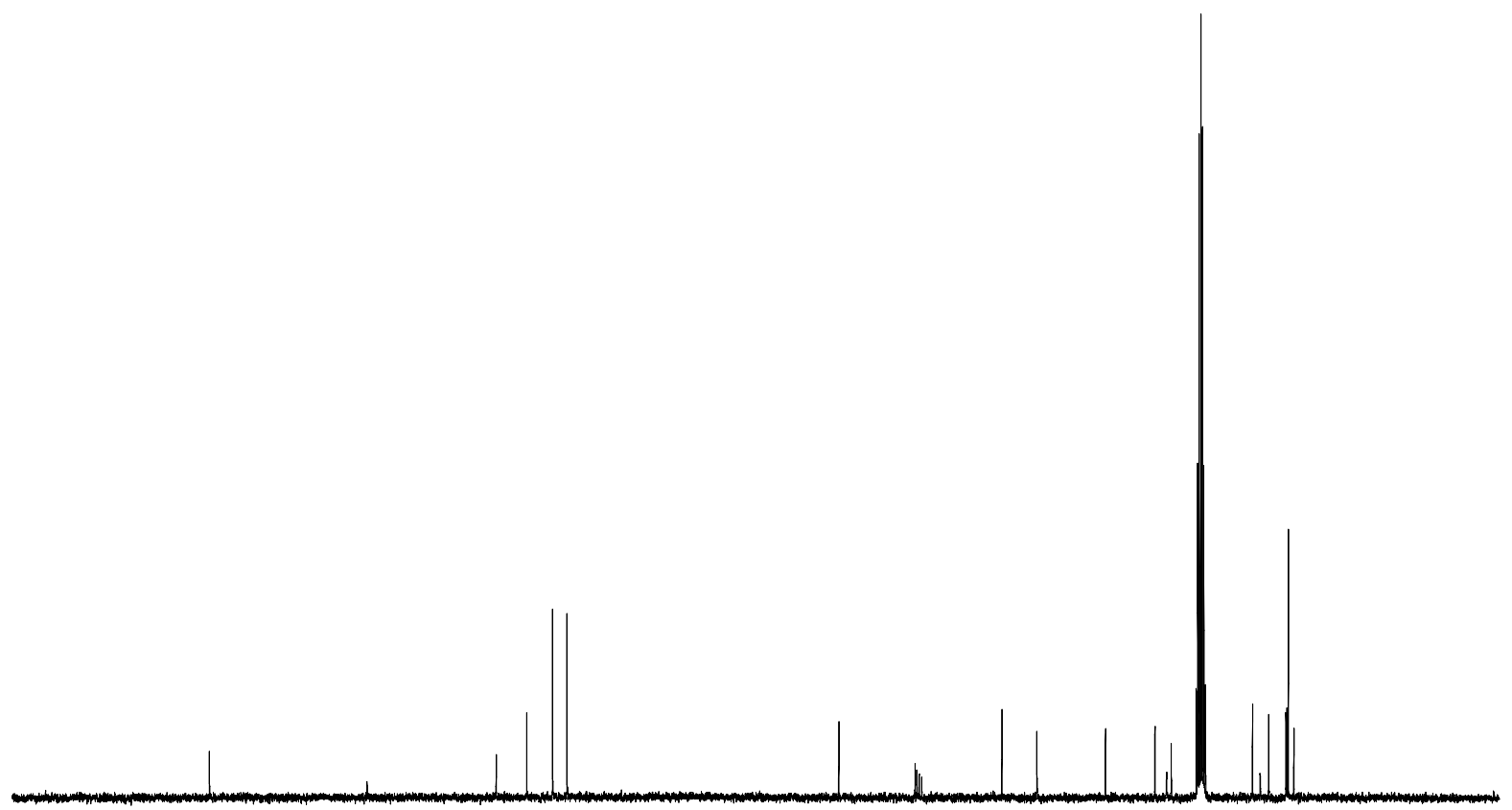

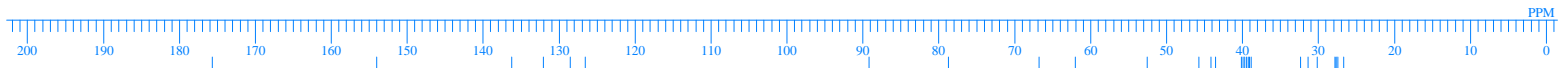

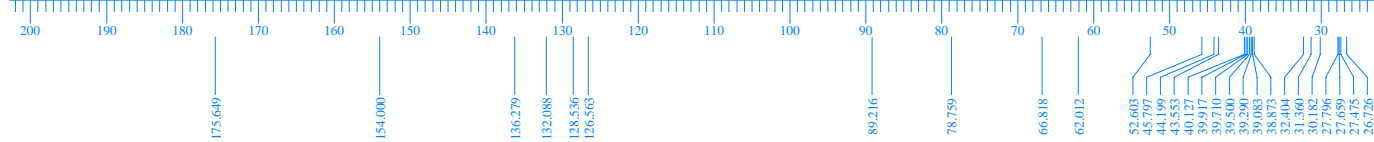




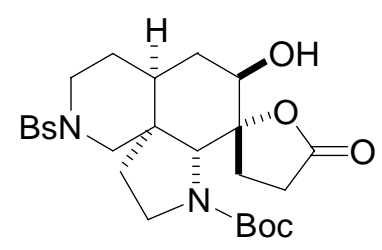

19b
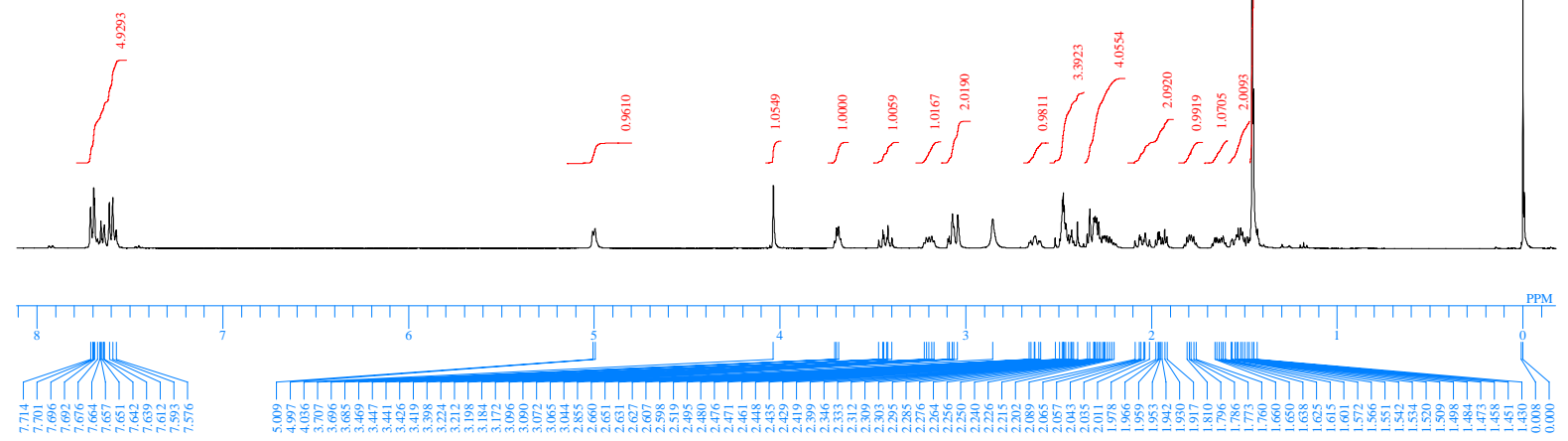

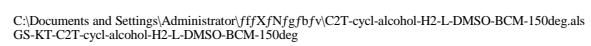

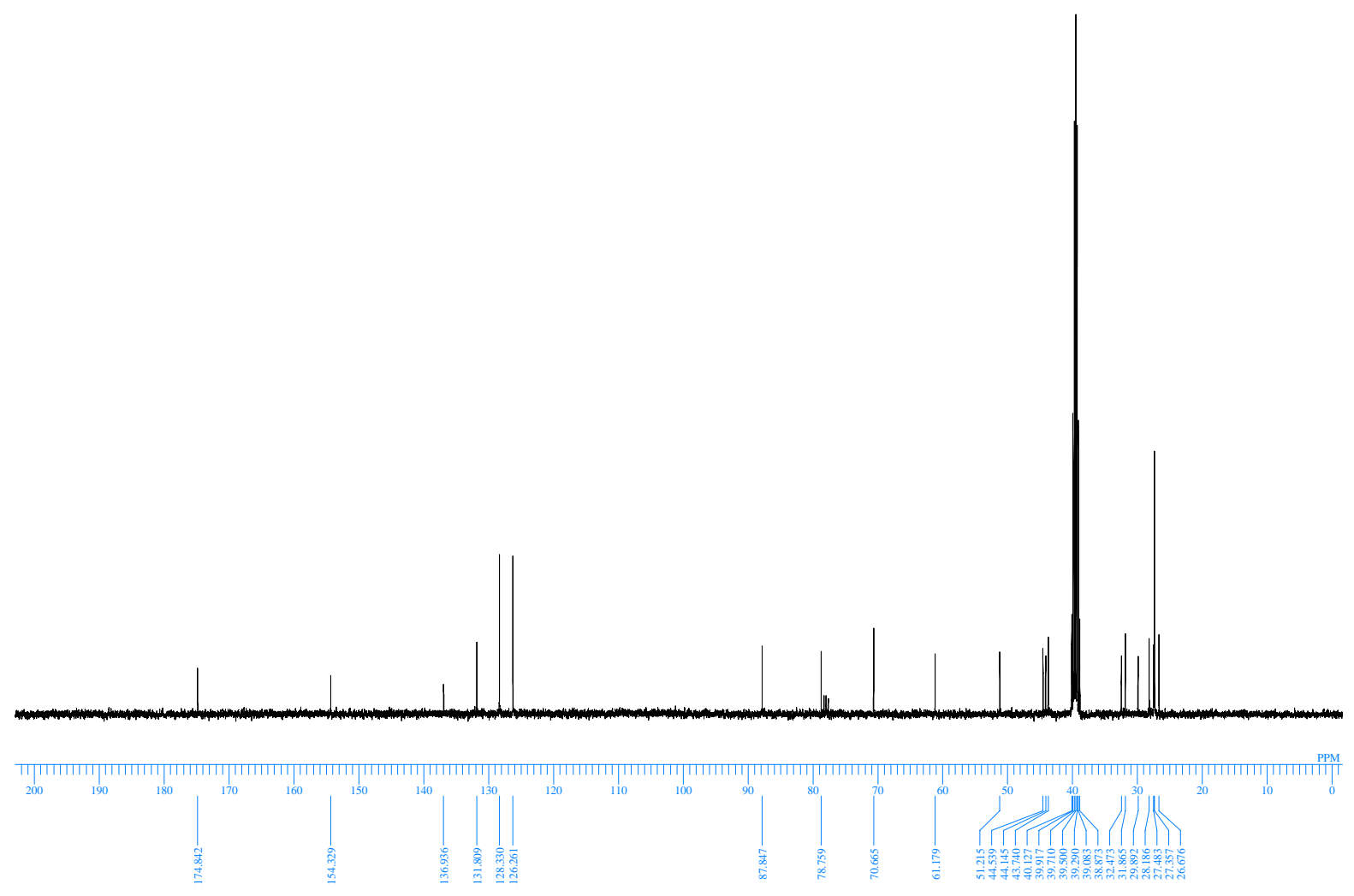




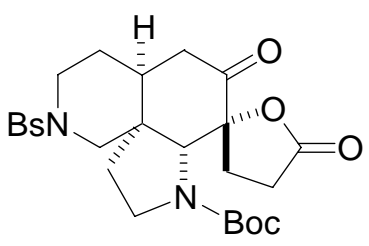

20

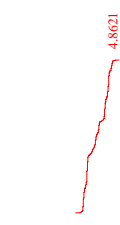

$\int$

Wh

H.

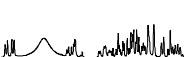

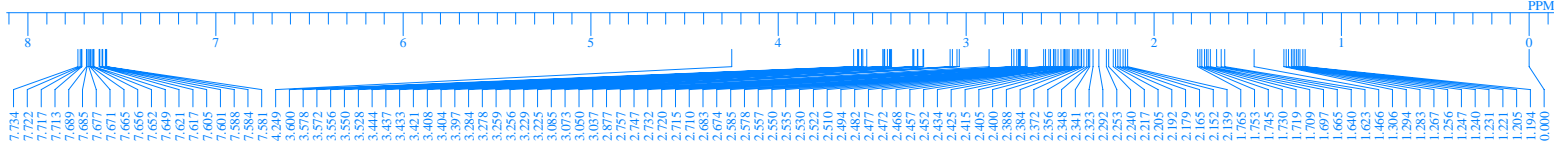

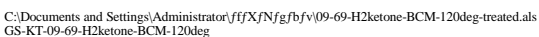

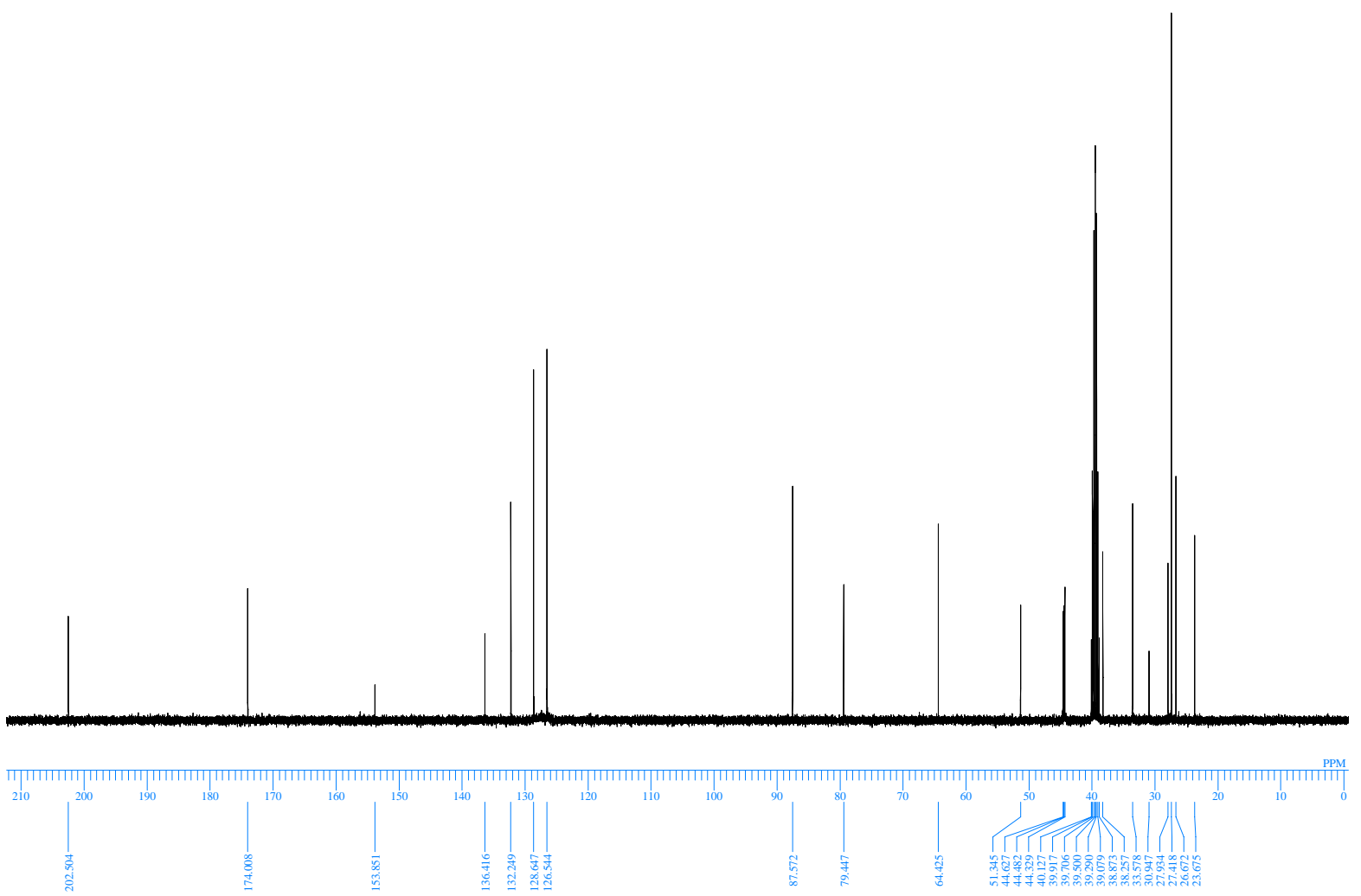




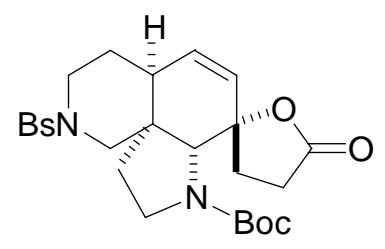

22

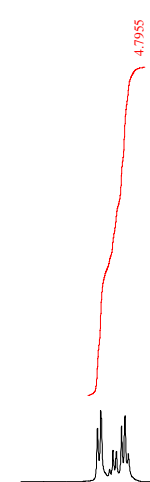

x

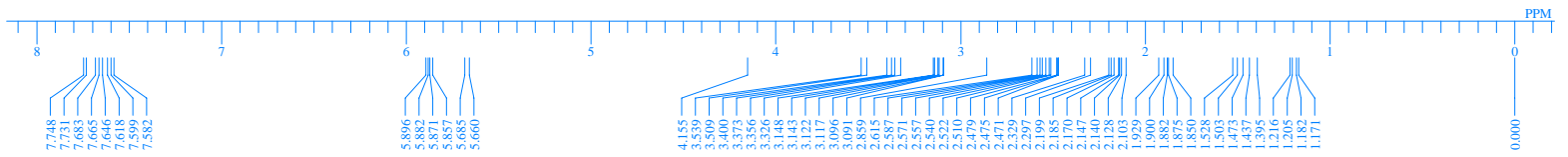

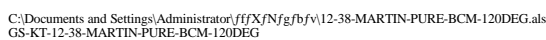

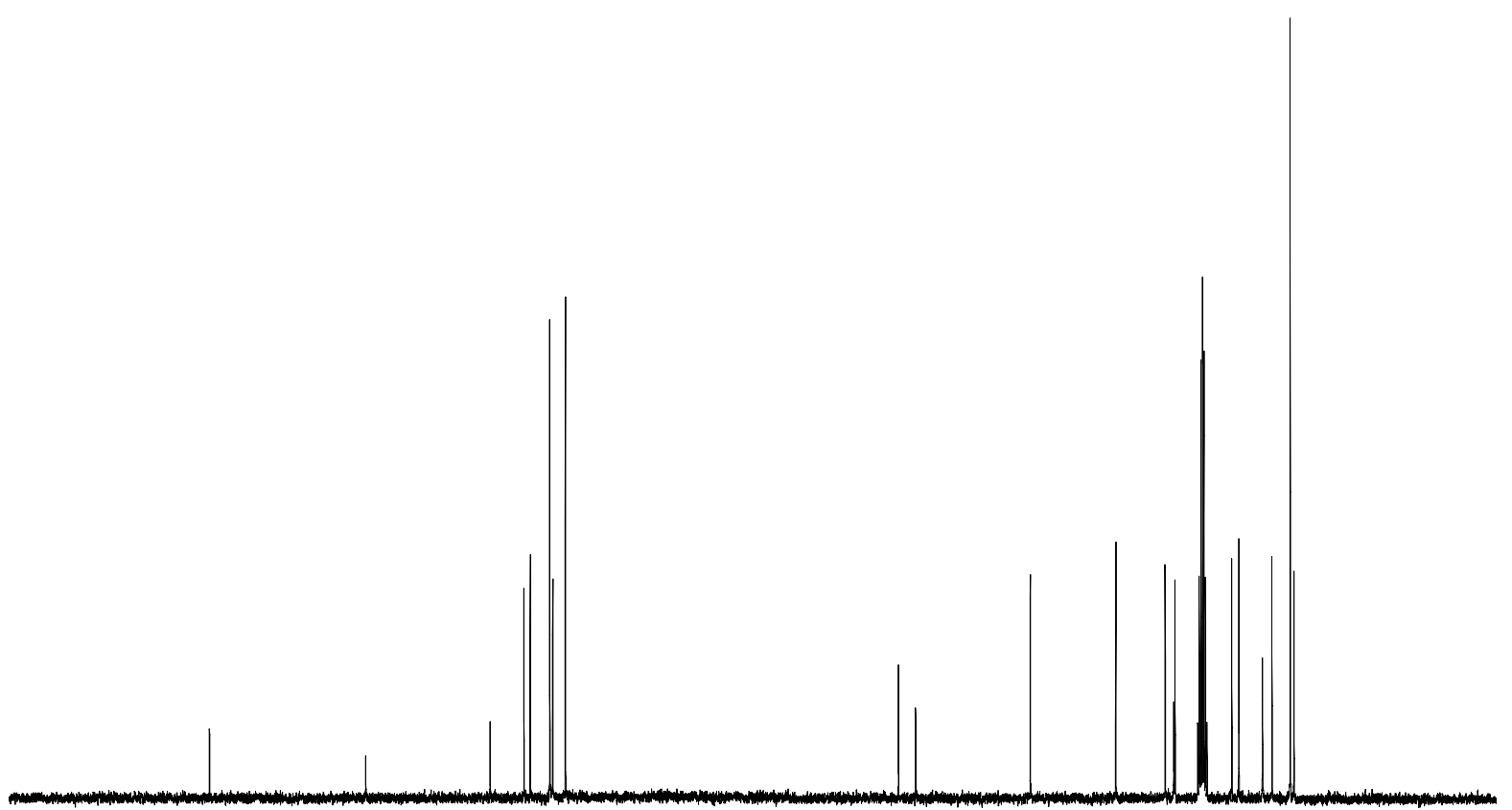

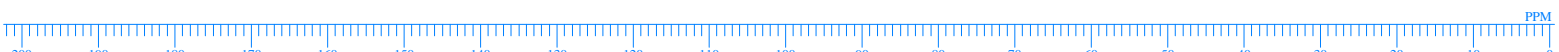

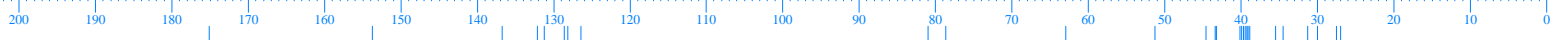

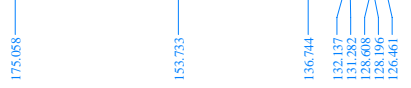

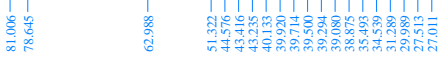




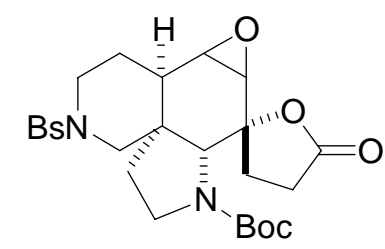

23
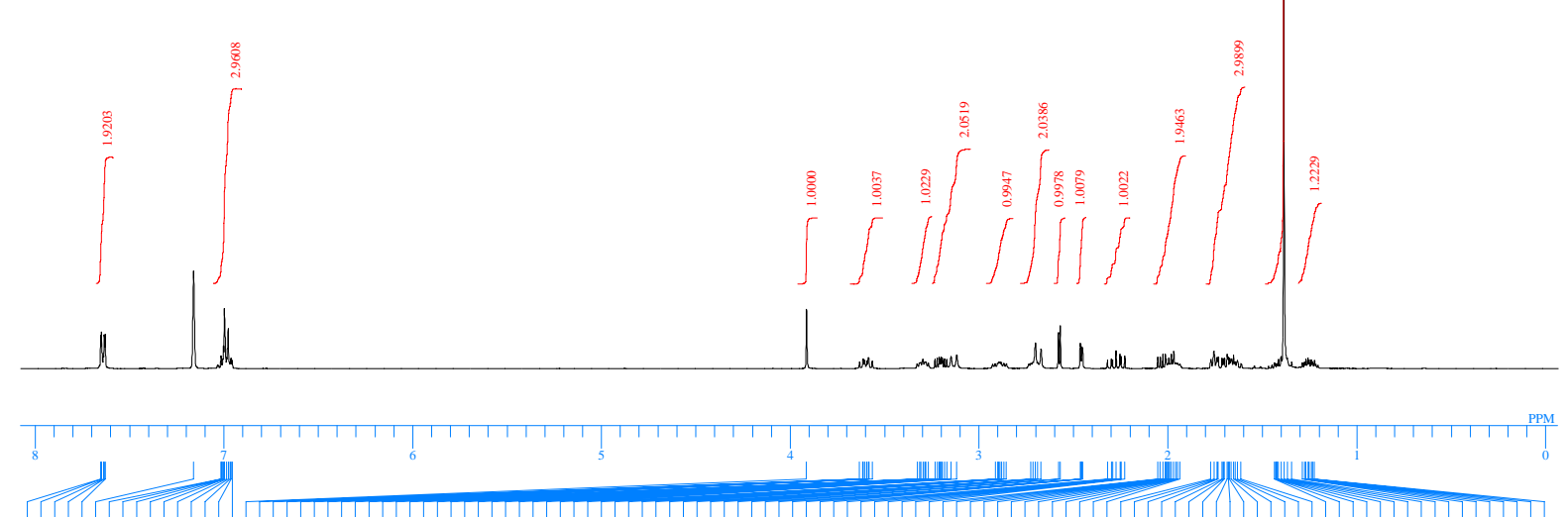

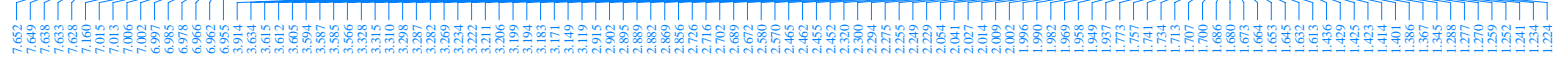

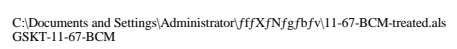

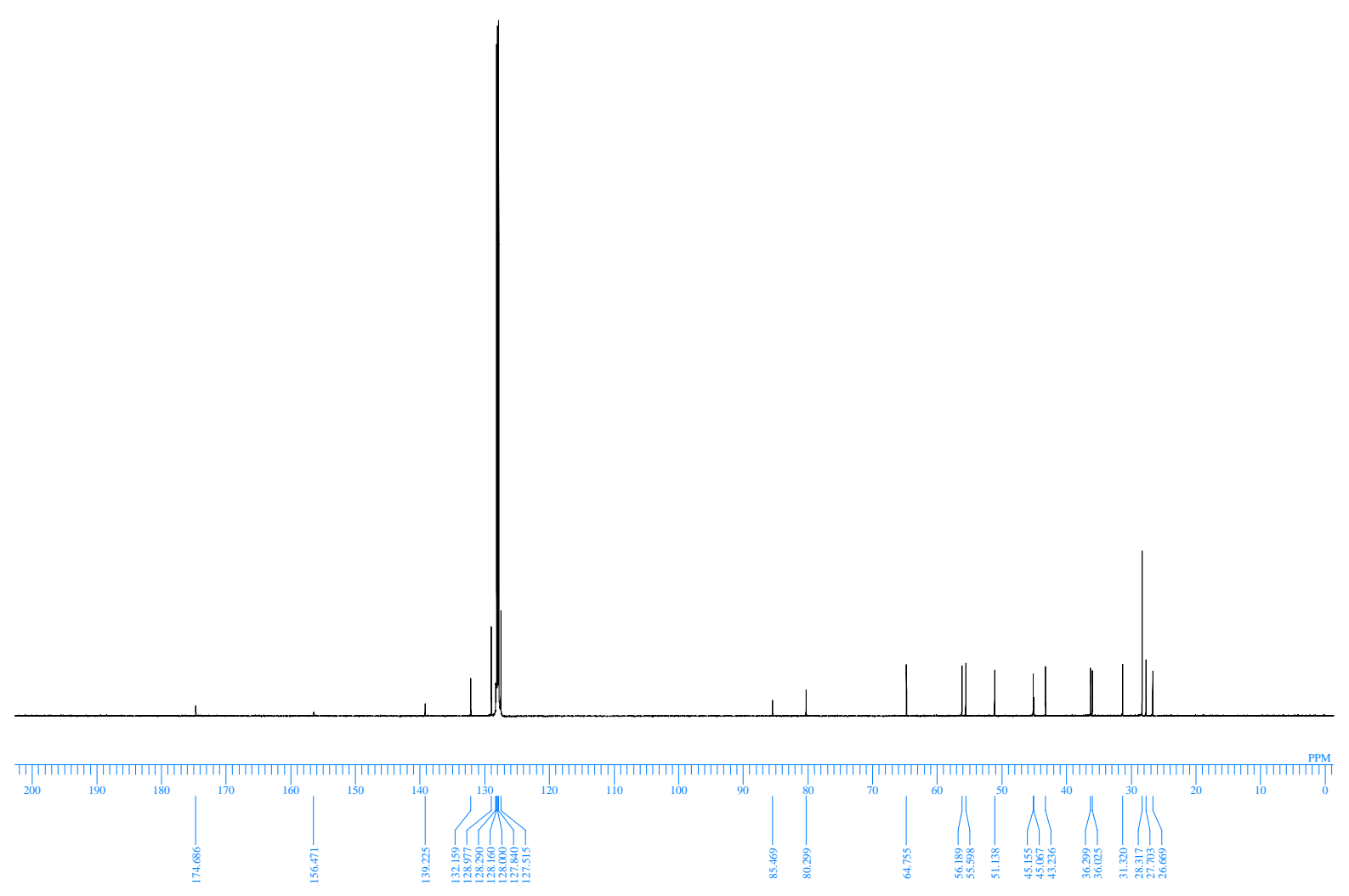



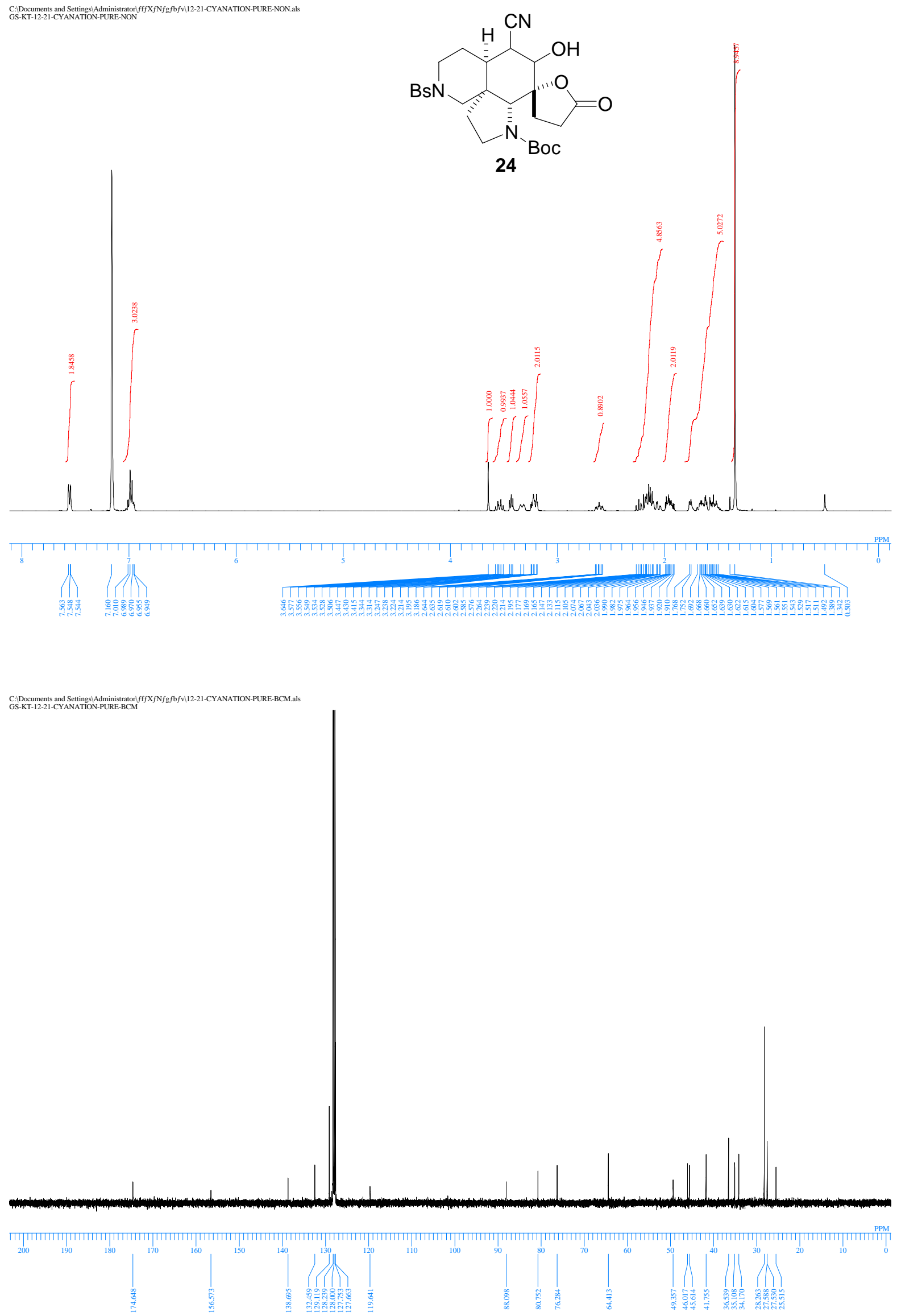

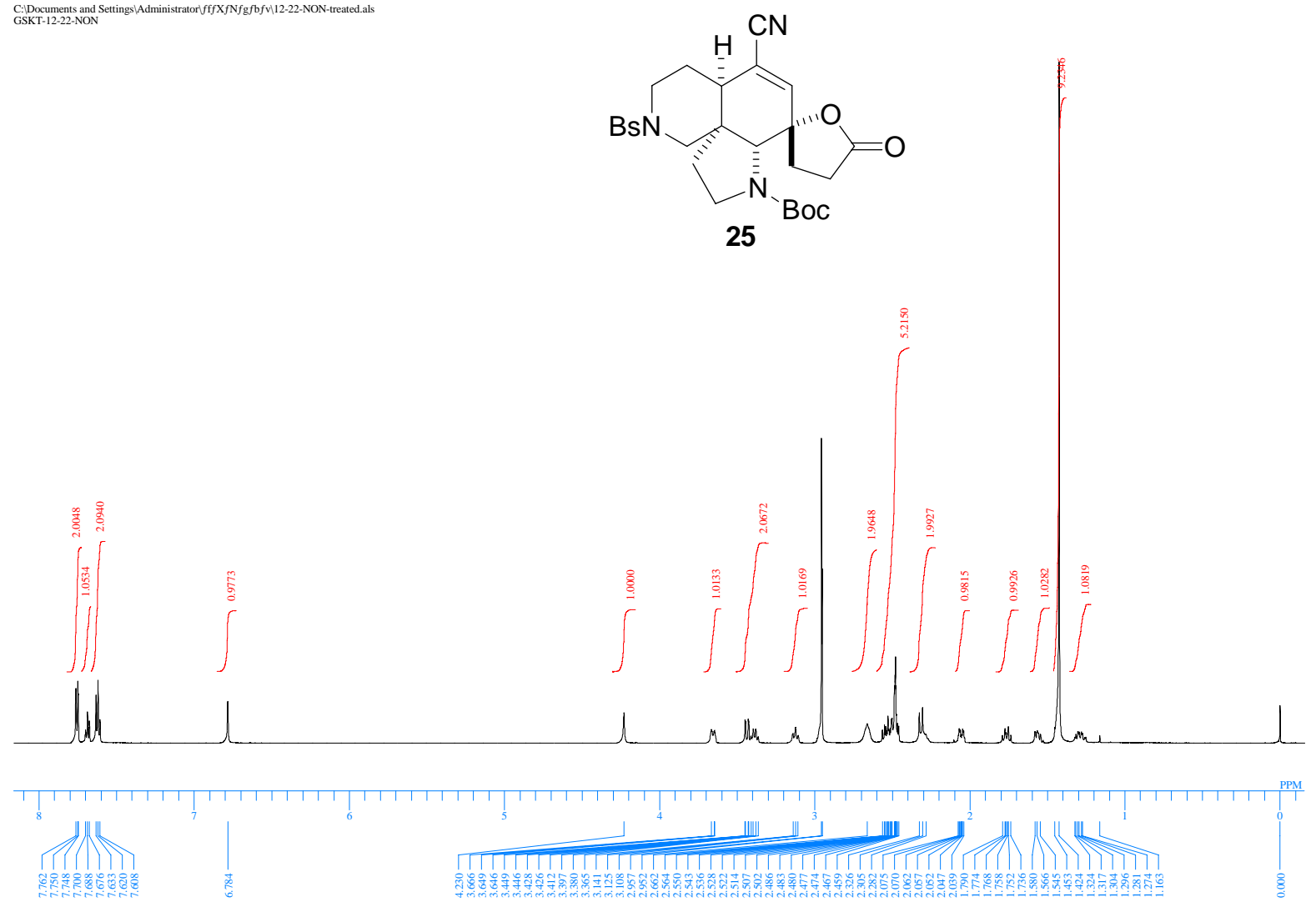

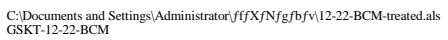

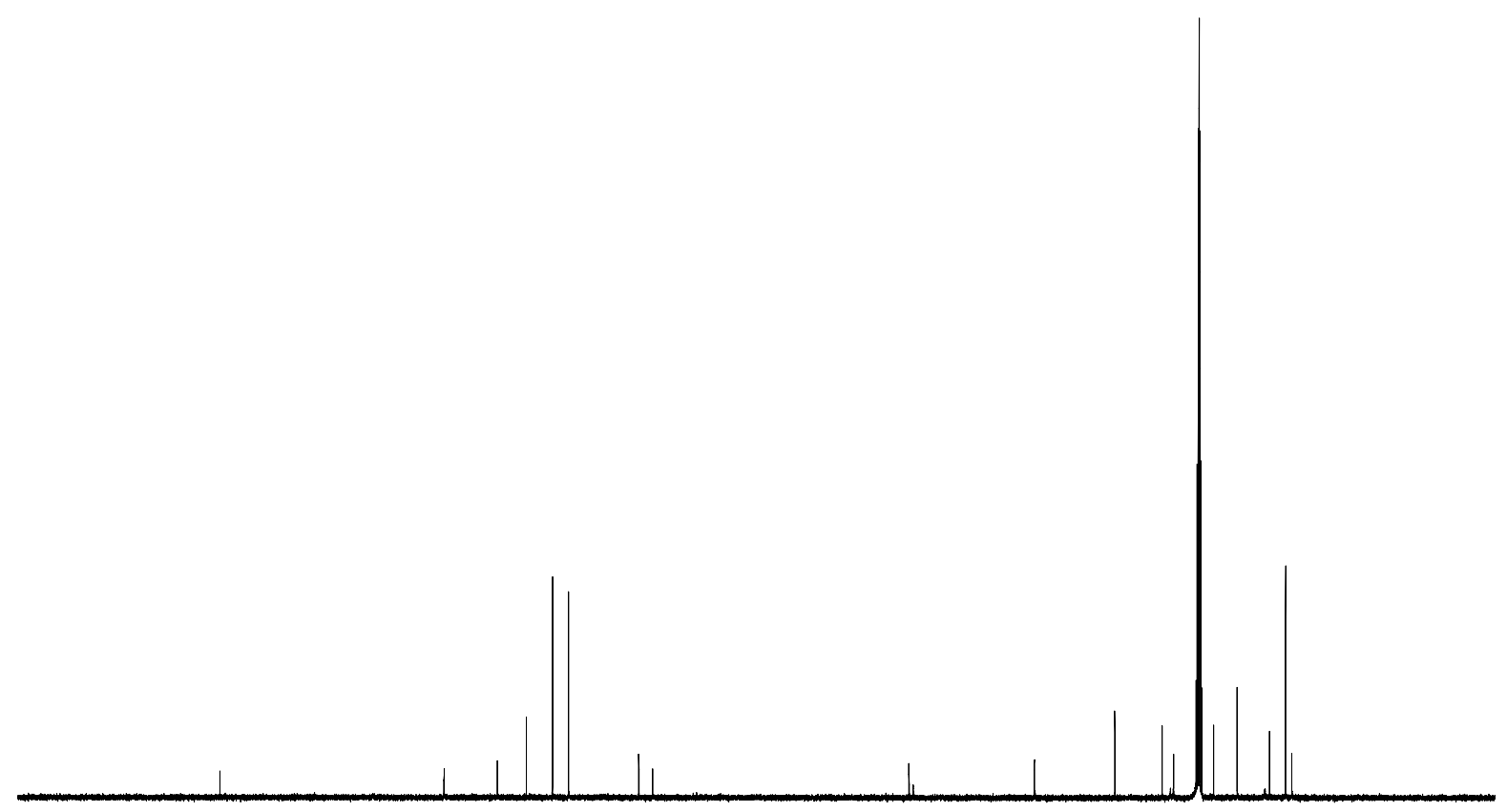

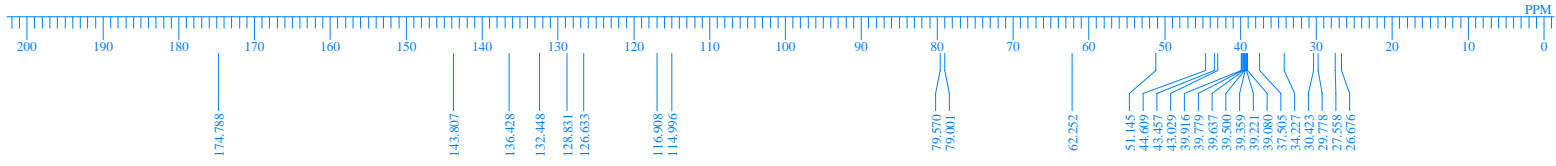


C:Documents and Settings $\backslash$ Administratorl $f f f X f N f g f b f v 112-22-100 d$ eglGSKT-12-22-COSY.1.als
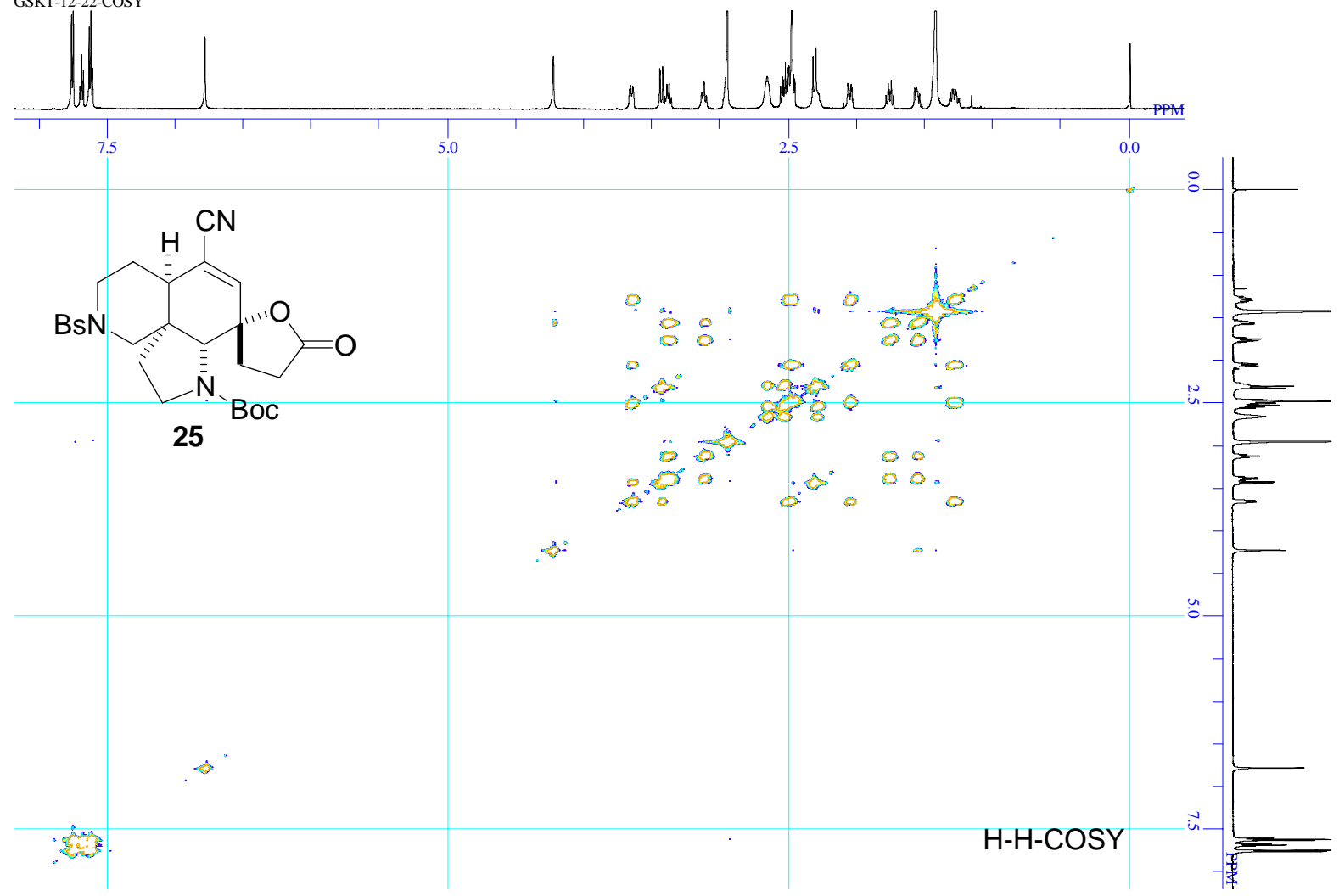

C: Documents and Setting $\backslash$ Administrator $/ f f \mathrm{X} f \mathrm{~N} f \mathrm{~g} f \mathrm{~b} f \mathrm{v} \backslash 12$-22-100deg|GSKT-12-22-HMQC-anal.als GSKT-12-22-HMQC

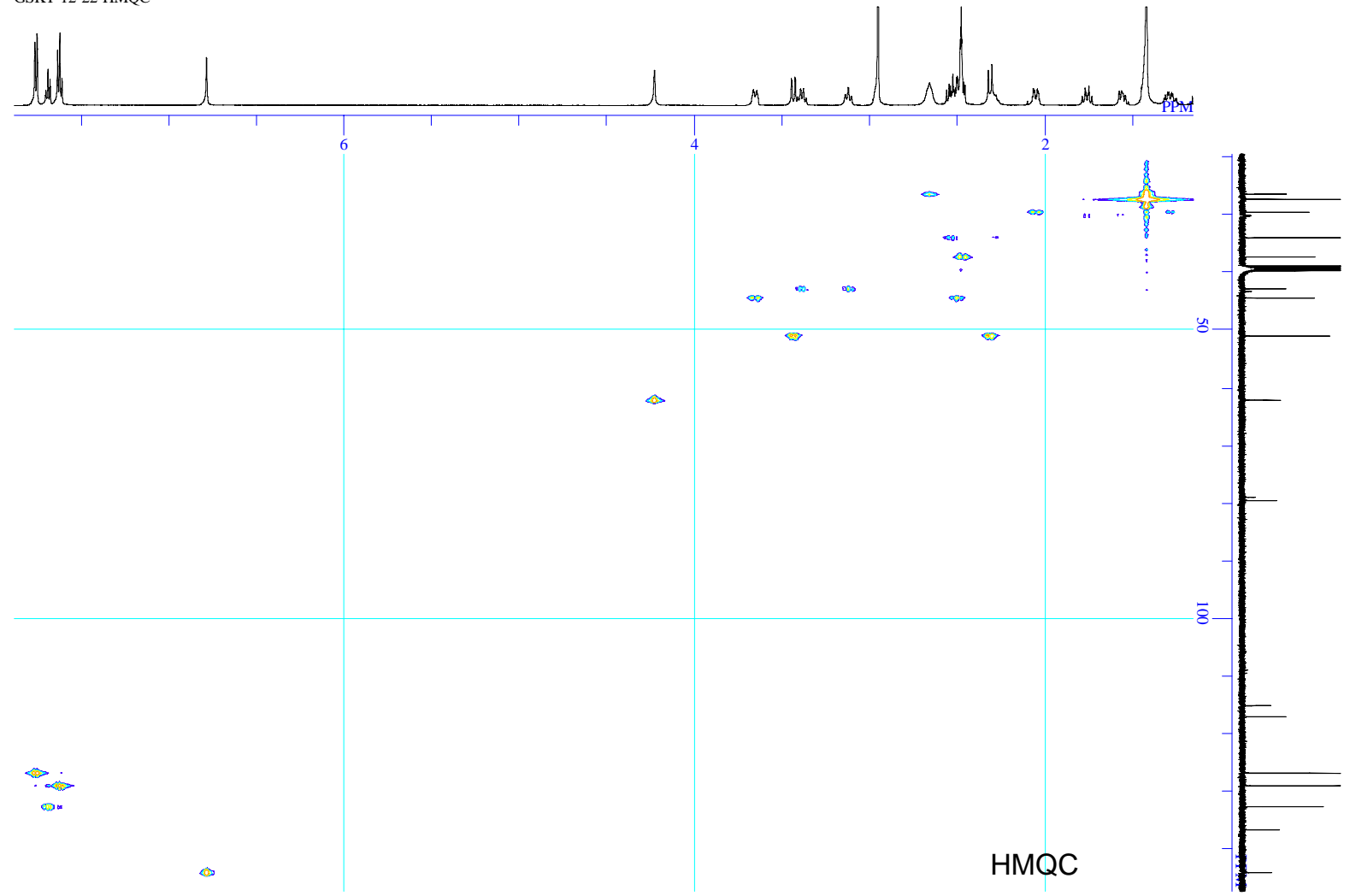



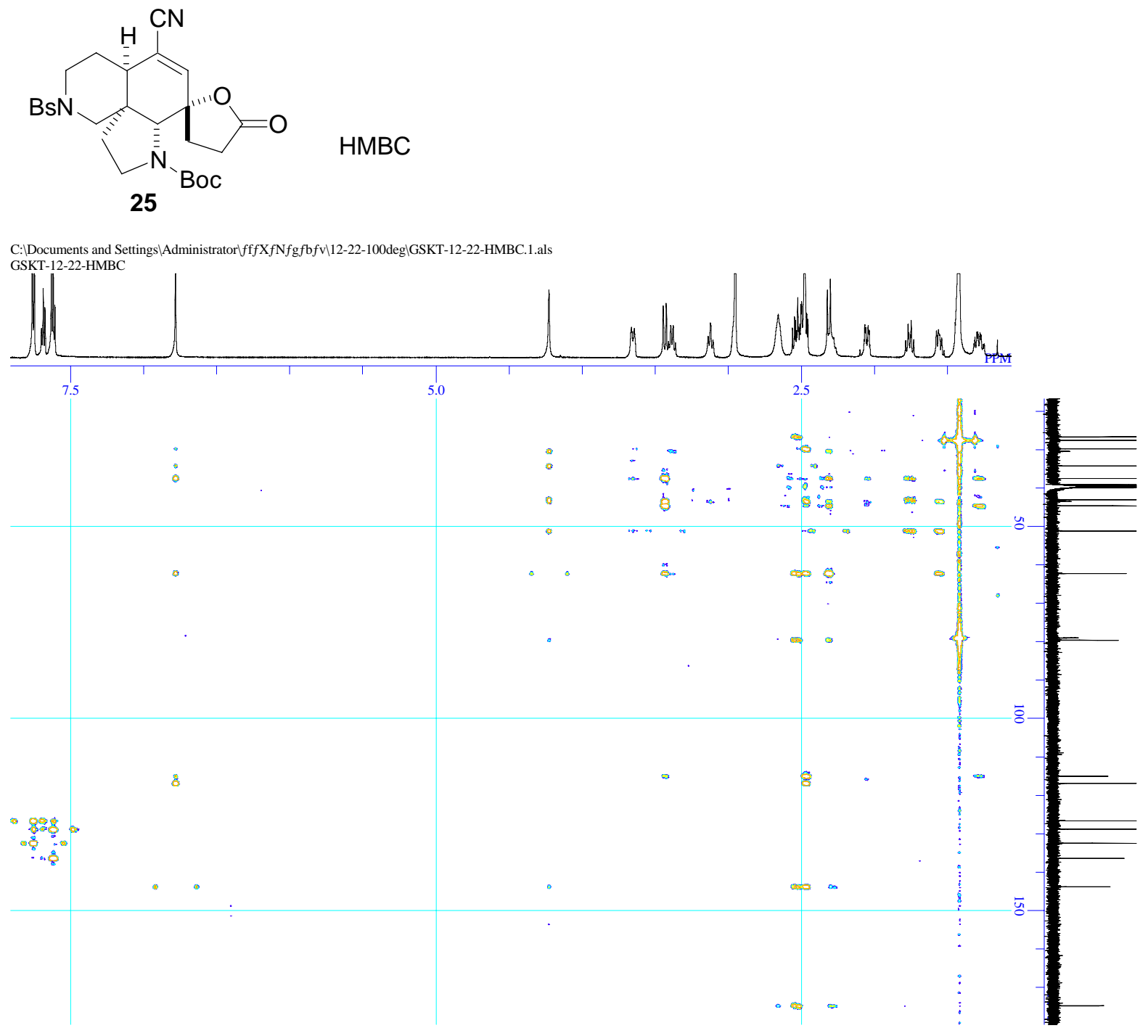

43 